\title{
А.А. Аникин
}

\section{ФИНАНСОВЫЙ ИНСТРУМЕНТАРИЙ}

\section{СТИМУАИРОВАНИЯ}

\section{«ЗЕАЕНЫХ ПРОЕКТОВ}

\section{В РОссиЙской эКоНомиКЕ}

ПРОБАЕМЫ И НАПРАВАЕНИЯ РАЗВИТИЯ

Монография 


\title{
А.А. Аникин
}

\section{ФИНАНСОВЫЙ ИНСТРУМЕНТАРИЙ СТИМУЛИРОВАНИЯ «ЗЕЛЕНЫХ» ПРОЕКТОВ В РОССИЙСКОЙ ЭКОНОМИКЕ: ПРОБЛЕМЫ И НАПРАВЛЕНИЯ РАЗВИТИЯ}

Сетевое научное издание

\author{
(C) А.А. Аникин, 2020 \\ (C) ИД «Академия Естествознания» \\ (C) АНО «Академия Естествознания» \\ ISBN 978-5-91327-658-2
}

Москва

2020 
УДК $330.15 ; 336.02 ; 336.027$

ББК 65.049

A67

Исследование выполнено при финансовой поддержке РФФИ в рамках научного проекта № 19-010-00356 «Совершенствование методологии оченки экологоэкономического развития регионов на основе кониепици устойчивого развития».

\section{Рецензенты:}

Горшкова Н.В. - д-р экон. наук., доцент;

Иванова Т.Б. - д-р экон. наук., профессор.

\section{Аникин А.А.}

Финансовый инструментарий стимулирования «зеленых» проектов в российской экономике: проблемы и направления развития: монография / под науч. ред. Аникиной И.Д. - М.: Издательский дом Академии Естествознания, 2020. - 128 с.

\section{ISBN 978-5-91327-658-2 \\ DOI 10.17513/np.430}

В монографии проанализированы инструменты поддержки и стимулирования экологических проектов, применяемых в российской экономике, а также лучший мировой опыт в данной области, разработан комплекс методических рекомендаций, направленных на повышение эффективности использования инструментов государственной финансовой поддержки экологических проектов, а именно: предложена матрица принятия управленческих решений по поддержке инвестиционного экопроекта, методика оценки инвестиционной привлекательности проектов с учетом их экологической значимости. Для повышения объективности инвестиционных управленческих решений предложен расчет эколого-экономического риска регионов и апробирован на примере 80 регионов Российской Федерации по предложенной методике, основанной на декаплинг-анализе. Предложенные методические решения могут помочь оценить эффективность региональной эколого-экономической политики региона, а инвесторы, реализующие проекты в регионах могут использовать результаты рейтинга, характеризующего риски региональной политики с сфере устойчивого развития, при расчете ставки дисконтирования инвестиционных проектов и принятии финансово-инвестиционных решений.

Рекомендовано для аспирантов, обучающихся по направлению 38.06.01 Экономика, магистрантов, обучающихся по направлению 38.04 .01 Экономика, 38.04.08 Финансы и кредит, менеджеров, предпринимателей, финансистов, а также для всех, интересующихся проблемами экологического менеджмента.

ISBN 978-5-91327-658-2 (c) А.А. Аникин, 2020

() ИД «Академия Естествознания»

(c) АНО «Академия Естествознания» 


\section{ОГЛАВЛЕНИЕ}

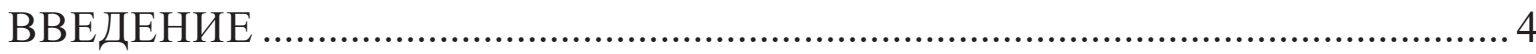

ГЛАВА 1. КОНЦЕПЦИЯ УСТОЙЧИВОГО ЭКОНОМИЧЕСКОГО

РОСТА И ТЕОРИЯ «ЗЕЛЕНОГО РОСТА» КАК БАЗИС

ДЛЯ СОЗДАНИЯ СИСТЕМЫ ЗЕЛЕНЫХ ФИНАНСОВ

В СОВРЕМЕННОЙ ЭКОНОМИКЕ ….................................................. 8

1.1. Методологические основы системы зеленых финансов: мировая и российская практика ......................................................... 8

1.2. Нормативно-информационное обеспечение устойчивого развития российских регионов в области зеленой экономики ......................... 21

ГЛАВА 2. АНАЛИЗ МЕТОДОВ И ИНСТРУМЕНТОВ

ФИНАНСИРОВАНИЯ ПРОЕКТОВ ЗЕЛЕНОЙ ЭКОНОМИКИ ................ 37

2.1. Анализ долгосрочных инструментов финансирования проектов зеленой экономики (зарубежный опыт)

2.2. Анализ механизмов и инструментов финансовой поддержки развития зеленых проектов в российской экономике

ГЛАВА 3. НАПРАВЛЕНИЯ СОВЕРШЕНСТВОВАНИЯ ИНСТРУМЕНТАРИЯ ФИНАНСИРОВАНИЯ ПРОЕКТОВ ЗЕЛЕНОЙ ЭКОНОМИКИ В РОССИЙСКОЙ ФЕДЕРАЦИИ

3.1. Роль и участие государства в стимулировании зеленой экономики и развитии рынка зеленого финансирования

3.2. Оценка эколого-экономического риска российских регионов ............. 84

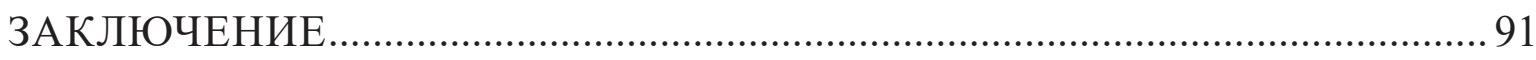

СПИСОК ИСПОЛЬЗОВАННЫХ ИСТОЧНИКОВ ........................................ 94

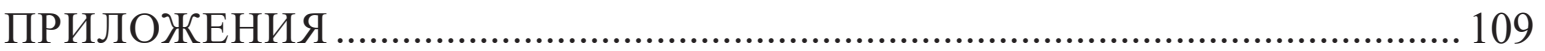




\section{ВВЕДЕНИЕ}

Экологическая проблематика является чрезвычайно актуальной в современном мире. Проблема изменения климата - одна из самых серьезных проблем нашего времени, находящаяся в фокусе интересов как на мировом уровне, так и на уровне каждого индивида. Изменение климата становится критически важной проблемой для развития страны на макроэкономическом уровне, но решение климатических и экологических проблем зависит и от каждой компании, и от каждого человека. Задача государственной политики в сфере экологии - создание условий и стимулов для роста инвестиций в зеленою экономику и модернизация налогово-бюджетной политики.

Российская система эко-финансирования находится на данном этапе в стадии становления: созданы основные элементы этой системы, приняты основополагающие стратегии и нормативные документы. В то же время остаются проблемы, связанные с недостаточностью методик оценки рисков инвестирования в экологические проекты и программы, с несовершенством финансовых стимулов эко-инвестирования. В связи с этим проблемы анализа, оценки и совершенствования финансового инструментария стимулирования зеленых проектов в российской экономике являются актуальными.

Значительный вклад в изучение проблемных аспектов мониторинговой оценки эффективности устойчивого развития в российской экономике внесли отечественные ученые: Бобылев С., Минаков В. и др. Возможности финансирования эко-проектов в российской экономике исследовали в своих трудах: Богачева О. и Смородинов О. (Центр бюджетной политики Научно-исследовательского финансового института), Тютюкина Е., Седаш Т., Каменева Е. (Финансовый университет при Правительстве Российской Федерации), Гутборг М., Храплива Ю. (компания Baker McKenzie), Володин С. (ВШЭ) и др. Анализом налогового инструментария стимулирования зеленых проектов в российской экономике занимаются такие исследователи как: Бобошко Н., Горкина И., Филичева Т. и др. Научно-аналитические материалы по исследуемой тематике готовят такие организации как: Банк России, Всемирный банк (The World Bank), Организация Объединенных Наций $(\mathrm{OOH})$ и др. 
Целью исследования явилось развитие методов и финансового инструментария стимулирования проектов зеленой экономики в Российской Федерации. Выделим основные результаты исследования:

1. К рискам процессов реализации климатических соглашений для российской экономики относятся следующие риски: рост себестоимости углеродного топлива, невысокое развитие возобновляемых источников энергии, увеличение рисков технологического отставания российской экономики, высокая неопределённость в понимании механизмов и направлений дельнейшей реализации Парижских соглашений. Проведен анализ стран с высокими запасами угля на предмет развития альтернативной энергетики, рассмотрены жесткие и мягкие механизмы реализации Парижских соглашений и сделан вывод о том, что при конкретизации механизмов и инструментов экологической политики необходим учет специфики российской экономики, особенностей климата, уровня технологического и технического развития, наличия и количества и качества природных ресурсов, а также политические факторы.

2. Факторы формирования источников финансирования экологических проектов целесообразно классифицировать по группам: экзогенные (макро- и мезо-факторы), оказывающие влияние на формирование инвестиционной стратегии компании /инвестора; эндогенные корпоративные факторы, учитывающие специфические факторы компании / инвестора и ESG-факторы, а также эндогенные факторы экологических проектов, учитывающие вклад эко-проектов в изменение стоимости компании. Среди экзогенных факторов выделен фактор экологоэкономического состояния региона, который предлагается оценивать на основе декаплинг-анализа. Учет ESG - факторов предлагается вести на основе анализа показателей: экологических, социальных, управленческих. Эндогенные факторы экологического проекта, помимо традиционных показателей, применяемых при оценке, должны учитывать экологическую, социальную, политическую значимость проекта.

3. Особенностями «зеленых» облигаций, отличающих их от других ценных бумаг, является целевой характер (инвестиции в эко-проекты) и наличие обязательных маркетов соответствия принципам зеленых финансовых инструментов, которые необходимо учитывать при разработке механизмов финансового стимулирования эко-проектов. Классификацию мер государственной поддержки проектов зеленой экономики целесообразно осуществлять по критериям: 1) форма участия: прямая и косвенная поддержка, 2) виды поддержки: админи- 
стративные и экономические (финансовые). К административным мерам отнесены институциональные меры (формирование «контура» поддержки рынка зеленого финансирования), организационные (организация научно-исследовательской работы по тематике зеленых финансов и экономики и разработка методических документов по классификации и оценке рисков). К мерам экономической (финансовой) поддержки относятся прямые меры (выпуск государственных и муниципальных облигаций, субсидии, гранты, госзакупки и др.) и косвенные (экологические налоги и сборы, субсидирование процентных ставок, гарантии, государственное страхование и др.).

4. Возможностями зеленой экономики для российской экономики являются: расширение возможностей привлечение инвестиций, повышение/сохранение конкурентоспособности компаний и продукции, в т.ч. во внешнеэкономических коммуникациях, увеличение стимулов разработки новых инновационных технологий (наилучших доступных технологий - НДТ). Среди угроз игнорирования зеленой экономики выделим следующие: потеря конкурентоспособности компаний и продукции, рост рисков внешнеторговых барьеров, риск закрытия финансовых рынков).

5. С целью учета взаимосвязи взаимозависимости экономического развития регионов и территорий и росте (или уменьшении) экологических угроз и оценки эколого-экономических рисков регионов автором предложена методика углубленного декаплинг-анализа, позволяющая оценить эколого-экономическое состояние и риски регионов. Методика была апробирована на примере 80 российских регионов, что позволило ранжировать их по рейтингу «эколого-экономического риска».

Новизна результатов проведенного исследования заключается в разработке предложений, являющихся основой методологии принятия решений о целесообразности инвестирования в эко-проекты, и состоит в следующем:

- выделены риски последствий реализации климатических соглашений для российской экономики: риски увеличения топливных затрат в структуре себестоимости продукции; риски невысокого развития возобновляемых источников энергии, политические риски реализации климатических соглашений, что требует координации стратегических планов и программ российской экономики;

- уточнена классификация факторов формирования источников финансирования эко-проектов посредством: 1) выделения фактора 
эколого-экономического состояния региона среди экзогенных факторов; 2) ESG-факторов среди эндогенных корпоративных факторов; 3) предложением учитывать эндогенные факторы эко-проекта, что является основной для разработки показателей оценки целесообразности инвестирования в эко-проекты;

- уточнена классификация мер государственной поддержки по классификационным признакам: по форме участия (прямая и косвенная поддержка) и по видам поддержки (административные и экономические (финансовые)) и выделены применяемые меры поддержки в российской экономике;

- сформулированы возможности зеленой экономики (формирование стратегических конкурентных преимуществ компаний и продуктов, расширение возможностей финансирования, улучшение странового имиджа) и угрозы ее игнорирования (закрытие рынков, усиление международных санкций, потеря конкурентоспособности компаниями), что обосновывает необходимость мер государственной поддержки и стимулирования эко-проектов российских компаний;

- предложен расчет уровня «эколого-экономического риска» регионов, основанный на авторской методике углубленного декаплинг-анализа, показана необходимость управления конкурентоспособностью регионов через проводимую региональную экологическую и экономическую политику на федеральном и региональном уровнях.

Теоретическая значимость исследования состоит в развитии теоретической базы решения актуальной задачи совершенствования мер стимулирования инвестиций в эко-проекты и анализа рисков инвестирования на основе мониторинга и оценки эколого-экономического состояния регионов, что позволит более полно учитывать взаимосвязь экологического и экономического развития регионов. Полученные теоретические положения могут быть использованы при проведении дальнейших исследований в области становления эко-финансов и устойчивого развития регионов. Практические результаты исследования заключаются в возможности использования предложенных моделей и инструментальных средств при разработке мер стимулирования и оценке рисков инвестирования в проекты зеленой экономики, а также при мониторинге и оценке эколого-экономических рисков регионов. 


\section{ГЛАВА 1. КОНЦЕПЦИЯ \\ УСТОЙЧИВОГО ЭКОНОМИЧЕСКОГО РОСТА \\ И ТЕОРИЯ «ЗЕЛЕНОГО РОСТА» КАК БАЗИС ДЛЯ СОЗДАНИЯ СИСТЕМЫ ЗЕЛЕНЫХ ФИНАНСОВ В СОВРЕМЕННОЙ ЭКОНОМИКЕ}

\section{1. Методологические основы системы зеленых финансов: мировая и российская практика}

В современном мире экологические факторы становятся одними из ключевых в экономической деятельности человека. ООН в 2016 году приняла 17 целей устойчивого развития (ЦУР) в области устойчивого развития до 2030 года. Достижение целей направлено на ликвидацию бедности, борьбу с неравенством, решение климатических проблем, защиту окружающей среды. Россия также присоединилась к Повестке дня в области устойчивого развития и формирует национальную систему целей устойчивого развития [1]. Объем средств, необходимый для достижения ЦУР ООН оценивается в 30 трлн. долл. [2, с.6]. Для аккумулирования и распределения необходимых финансовых средств создается глобальная система «зеленых» финансов - экосистема зеленого финансирования. В основу систему положено единство трех факторов: экологических, экономических, социальных (рис. 1, таблица 1).

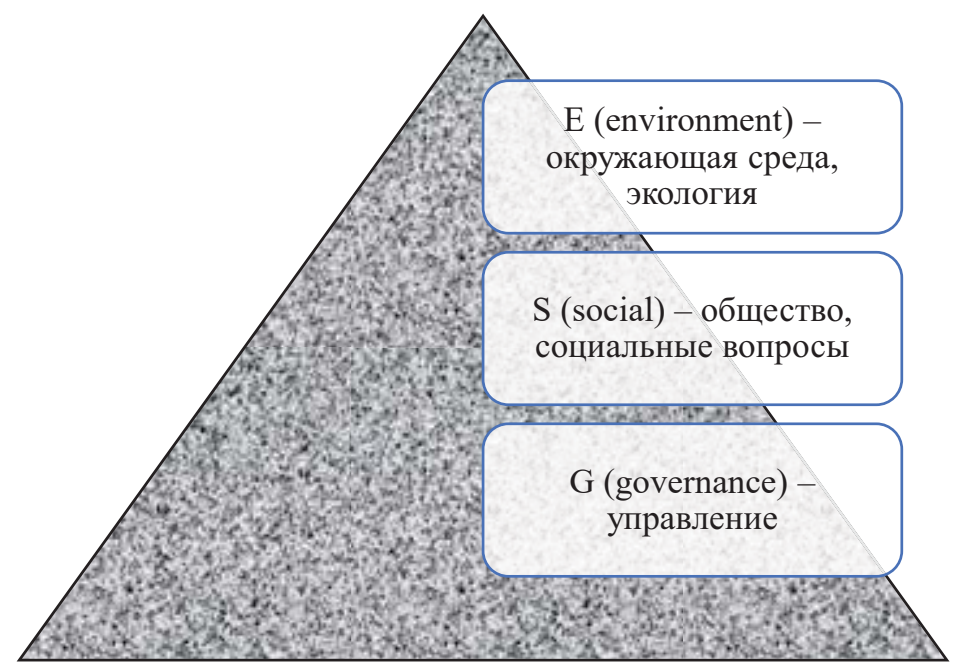

Рис. 1. Составляющие системы эко-финансирования. Источник: составлено автором на основе [2, с.6] 
Составляющие зеленого финансирования

\begin{tabular}{|c|c|}
\hline Определение (англ.) & Определение (русск.) \\
\hline \multicolumn{2}{|c|}{ Зеленое финансирование } \\
\hline $\begin{array}{l}\text { Green finance' generally refers to the } \\
\text { process of taking due account of environ- } \\
\text { mental and social considerations when } \\
\text { making investment decisions, leading to } \\
\text { increased investment in longer-term and } \\
\text { sustainable activities. All three compo- } \\
\text { nents - environmental, social and gover- } \\
\text { nance (ESG) - are integral parts of sus- } \\
\text { tainable economic development and } \\
\text { finance. In the EU's policy context green } \\
\text { finance is understood as finance to support } \\
\text { economic growth while reducing pres- } \\
\text { sures on the environment and taking into } \\
\text { account social and governance aspects. } \\
\text { Green finance also encompasses transpar- } \\
\text { ency on risks related to ESG factors that } \\
\text { may impact the financial system, and the } \\
\text { mitigation of such risks through the ap- } \\
\text { propriate governance of financial and cor- } \\
\text { porate actors. }\end{array}$ & $\begin{array}{l}\text { «Зеленое финансирование», как прави- } \\
\text { ло, относится к процессу должного } \\
\text { учета экологических и социальных со- } \\
\text { ображений при принятии инвестицион- } \\
\text { ных решений, что ведет к увеличению } \\
\text { инвестиций в долгосрочные и устойчи- } \\
\text { вые виды деятельности. Все три компо- } \\
\text { нента - экологический, социальный } \\
\text { и управленческий (ESG) - являются не- } \\
\text { отъемлемыми частями устойчивого } \\
\text { экономического развития и финансов. } \\
\text { В контексте политики ЕС зеленые фи- } \\
\text { нансы понимаются как финансы } \\
\text { для поддержки экономического роста } \\
\text { при одновременном снижении нагруз- } \\
\text { ки на окружающую среду и с учетом } \\
\text { «социальных и управленческих аспек- } \\
\text { тов. Зеленое финансирование также } \\
\text { включает в себя прозрачность рисков, } \\
\text { связанных с факторами ЕSG, которые } \\
\text { могут повлиять на финансовую систе- } \\
\text { му, и смягчение таких рисков посред- } \\
\text { ством надлежащего управления финан- } \\
\text { совыми и корпоративными субъектами. }\end{array}$ \\
\hline \multicolumn{2}{|c|}{ Экологическая составляющая } \\
\hline $\begin{array}{l}\text { More specifically, environmental consid- } \\
\text { erations refer to climate change mitiga- } \\
\text { tion and adaptation, as well as the envi- } \\
\text { ronment more broadly and the related } \\
\text { risks (e.g. natural disasters). }\end{array}$ & $\begin{array}{l}\text { Более конкретно, экологические сообра- } \\
\text { жения относятся к смягчению послед- } \\
\text { ствий изменения климата и адаптации } \\
\text { к ним, а также к окружающей среде } \\
\text { в целом и связанным с этим рискам (на- } \\
\text { пример, стихийным бедствиям). }\end{array}$ \\
\hline \multicolumn{2}{|c|}{ Социальная составляющая } \\
\hline $\begin{array}{l}\text { Social considerations may refer to issues } \\
\text { of inequality, inclusiveness, labor rela- } \\
\text { tions, investment in human capital and } \\
\text { communities. }\end{array}$ & $\begin{array}{l}\text { Социальные соображения могут касать- } \\
\text { ся вопросов неравенства, инклюзивно- } \\
\text { сти, трудовых отношений, инвестиций } \\
\text { в человеческий капитал и сообщества. }\end{array}$ \\
\hline
\end{tabular}


Окончание табл. 1

\begin{tabular}{|c|c|}
\hline Определение (англ.) & Определение (русск.) \\
\hline \multicolumn{2}{|c|}{ Управление } \\
\hline $\begin{array}{l}\text { The governance of public and private in- } \\
\text { stitutions, including management struc- } \\
\text { tures, employee relations and executive } \\
\text { remuneration, plays a fundamental role in } \\
\text { ensuring the inclusion of social and envi- } \\
\text { ronmental considerations in the deci- } \\
\text { sion-making process }\end{array}$ & $\begin{array}{l}\text { Управление государственными и част- } \\
\text { ными учреждениями, включая структу- } \\
\text { ры управления, взаимоотношения с ра- } \\
\text { ботниками и вознаграждение руководи- } \\
\text { телей, играет основополагающую роль } \\
\text { в обеспечении учета социальных и эко- } \\
\text { логических соображений в процессе } \\
\text { принятия решений. }\end{array}$ \\
\hline
\end{tabular}

Источник: составлено автором на основе [3].

Система зеленого финансирования (эко-финансирование) создается с учетом последствий хозяйственной деятельности человека. Она должна учитывать интересы разных целевых аудиторий (стейкхолдеров), что требует разработки методологического обеспечения, учитывающего эти интересы.

В мире создается система зеленого финансирования на трех уровнях: 1) международный уровень; 2) межрегиональный уровень; 3) национальный уровень. Многие страны уже прошли определенный этап создания национальных систем зеленых финансов, учитывающий национальные интересы и особенности (Нидерланды, Швеция, Великобритания, Франция, Китай, Гонконг, Малайзия, США, Бразилия. Марокко, Кения). Основные термины и определения. Сложившееся к настоящему времени понимание терминологии и определений в сфере зелёного финансирования представлено в Приложении А.

Россия находится пока в начале пути. Отметим, что сектор устойчивого развития на Московской бирже начал работать в августе 2019 г. и в котировальном листе данного сектора на данный момент (январь 2020 г.) находятся ценные бумаги только двух эмитентов. Российская национальная система зеленого финансирования создается и активно развивается, 2018 и 2019 гг. стали прорывными с точки зрения как разработки методологических материалов по данной проблематике, так и их внедрения на практике. Субъекты и объекты системы эко-финансирования представлены в таблице 2. 
Субъекты и объекты системы эко-финансирования

\begin{tabular}{|c|c|}
\hline $\begin{array}{c}\text { Субъекты } \\
\text { системы эко-финансирования }\end{array}$ & $\begin{array}{c}\text { Объекты } \\
\text { системы эко-финансирования }\end{array}$ \\
\hline $\begin{array}{l}\text { - органы регулирования финансового } \\
\text { рынка и уполномоченные органы в об- } \\
\text { ласти охраны окружающей среды; } \\
\text { - эмитенты и получатели финансовых } \\
\text { средств; } \\
\text { - финансирующие организации, инве- } \\
\text { сторы, управляющие активами, иные } \\
\text { участники финансового рынка; } \\
\text { - инфраструктурные и сервисные орга- } \\
\text { низации, в т.ч. организаторы биржевой } \\
\text { торговли, верификаторы, сертифициру- } \\
\text { ющие агентства; } \\
\text { - профессиональные, экспертные и ис- } \\
\text { следовательские организации }\end{array}$ & $\begin{array}{l}\text { - финансовые инструменты, в т.ч. зеле- } \\
\text { ные облигации, кредиты, займы, стра- } \\
\text { ховые и лизинговые продукты и др.; } \\
\text { - инструменты оценки риски и эффек- } \\
\text { тивности (рейтинги кредитоспособно- } \\
\text { сти, индикаторы, индексы, бенчмарки, } \\
\text { методики, аналитические материалы, } \\
\text { исследования, опросы, обзоры); } \\
\text { - центры сбора и структурирования } \\
\text { информации (реестры, базы данных). }\end{array}$ \\
\hline
\end{tabular}

Источник: составлено автором на основе [2].

Система соответствия принципам эко-финансирования включает следующие элементы:

- зеленая политика субъекта /эмитента и ответственные действия на рынках - подтверждается наличием внутренних документов;

- зеленая сертификация проекта или бизнеса - подтверждается результатами экспертиз;

- кредитоспособность субъекта /эмитента, устойчивость его бизнеса - подтверждается рейтингами;

- верификация зеленых финансовых инструментов принципам ответственного инвестирования - подтверждается заключением о соответствии;

- учет эмитируемых бумаг в национальных и/или международных реестрах.

Особенностями становления российской системы эко-финансирования являются: длительность разработки правил государством, отсутствие систем оценки рисков ESG -инвестирования; недостаточное представительство российских интересов при формировании глобальных правил. 
Рассмотрим мировую практику методологического обеспечения системь эко-финансов. Методология системы эко-финансов разрабатывается на различных уровнях и имеет институциональную поддержку (таблица 3).

Таблица 3

Институциональное обеспечение методологии эко-финансов

\begin{tabular}{|c|c|}
\hline Институты & Примечания \\
\hline \multicolumn{2}{|c|}{ Глобальный международный уровень } \\
\hline $\begin{array}{l}\text { Ассоциация ответственного инвести- } \\
\text { рования; } \\
\text { Международная некоммерческая орга- } \\
\text { низация Инициатива по климатиче- } \\
\text { ским облигациям; } \\
\text { Сеть устойчивого банковского финан- } \\
\text { сирования; } \\
\text { Международная ассоциация рынков ка- } \\
\text { питалов; } \\
\text { Центр зеленых финансов и инвестиций } \\
\text { Организации экономического сотруд- } \\
\text { ничества и развития; } \\
\text { Рабочая группа по раскрытию инфор- } \\
\text { мации, связанной с климатом } \\
\text { Сеть центральных банков и надзорных } \\
\text { органов для экологизации финансовой } \\
\text { системы; } \\
\text { Международная организация стандар- } \\
\text { тизации, стандарт «Управление воздей- } \\
\text { ствием изменения климата» ІСО 14090; } \\
\text { Инновационная лаборатория климати- } \\
\text { ческих финансов }\end{array}$ & $\begin{array}{l}\text { Principles for Responsible Investment, } \\
\text { PRI (https://www.unpri.org/); } \\
\text { Climate Bonds Initiative (https://www. } \\
\text { climatebonds.net); } \\
\text { Sustainable Banking Network (https:// } \\
\text { www.ifc.org/); } \\
\text { International Capital Market Association, } \\
\text { ICMA (https://www.icmagroup.org); } \\
\text { Centre on Green Finance and Investment, } \\
\text { OECD (www.oecd.org); } \\
\text { Task Force on Climate-related Financial } \\
\text { Disclosures, TCFD (https://www.fsb-tcfd. } \\
\text { org); } \\
\text { Network of Central Banks and Supervisors } \\
\text { for Greening the Financial System, NCGS } \\
\text { (https://www.ngfs.net); } \\
\text { ISO 14090:2019(en) Adaptation to climate } \\
\text { change - Principles, requirements and } \\
\text { guidelines (https://www.iso.org); } \\
\text { The Global Innovation Lab for Climate } \\
\text { Fin ance, GILCF (https://w ww. } \\
\text { climatefinancelab.org) }\end{array}$ \\
\hline \multicolumn{2}{|c|}{ Международный уровень } \\
\hline $\begin{array}{l}\text { Группы экспертов высокого уровня Ев- } \\
\text { ропейской комиссии; } \\
\text { Форум рынков капитала Ассоциации го- } \\
\text { сударств Юго-Восточной Азии, АСЕАН; } \\
\text { Исследовательская группа по зеленым } \\
\text { финансам G20; } \\
\text { Инициатива по развитию зеленых рын- } \\
\text { ков капитала в Азии и Африке «Обяза- } \\
\text { тельство Марракеша»; } \\
\text { Платформа «Зеленые финансы» Латин- } \\
\text { ской Америки и Карибского региона }\end{array}$ & $\begin{array}{l}\text { Technical expert group on sustainable } \\
\text { finance, TEG; High-level expert group on } \\
\text { sustainable finance, (https://ec.europa.eu) } \\
\text { ASEAN Capital Markets Forum, ACMF } \\
\text { (www.theacmf.org); } \\
\text { The G20 Green Finance Study Group, } \\
\text { GFSG (https://unepinquiry.org); } \\
\text { The Marrakech Pledge (marrakechpledge. } \\
\text { com); } \\
\text { Green Finance LAC, GFL (https://www. } \\
\text { greenfinancelac.org); }\end{array}$ \\
\hline
\end{tabular}


Окончание табл. 3

\begin{tabular}{|c|c|}
\hline Институты & Примечания \\
\hline \multicolumn{2}{|c|}{ Национальный уровень } \\
\hline $\begin{array}{l}\text { Национальные регуляторы, националь- } \\
\text { ные бизнес-ассоциации, эксперт- } \\
\text { ные структуры, биржи, рейтинговые } \\
\text { агентства }\end{array}$ & $\begin{array}{l}\text { Методологическую основу в области } \\
\text { зеленых финансов формируют как регу- } \\
\text { лирующие органы, так и биржи, про- } \\
\text { фессиональные и экспертные организа- } \\
\text { ции, неправительственные объедине- } \\
\text { ния, платформы, ассоциации и т.д. }\end{array}$ \\
\hline
\end{tabular}

Источник: составлено автором на основе [2].

Важным аспектом представляется разработанная Группой экспертов высокого уровня Европейской комиссии (TEG) таксономия в области зеленых финансов [4], она предполагает единую систему терминологии в области финансирования устойчивого развития.

Таксономия ЕС поможет внести существенный вклад в достижение следующих целей в области устойчивого развития:

1) смягчение последствий изменения климата;

2) адаптация к изменениям климата;

3) устойчивое использование и охрана водных ресурсов;

4) переход к циркулярной экономике, предотвращение и переработка отходов;

5) предотвращение загрязнения и борьба с ним;

6) защита здоровых экосистем [2, с.18,19].

Для соответствия таксономии ЕС компания должна вносить существенный вклад по крайней мере в одну экологическую цель и не наносить ущерба своей деятельностью остальным целям, а также соблюдать социальные гарантии. Группа разработала классификацию видов экономической деятельности, которые могут смягчить последствия изменения климата (таблица 4). На настоящее время таксономия, стандарты нефинансовой отчетности не являются обязательными для компаний. Таксономия помогает инвесторам и компаниям опередить «чистые» виды деятельности. Существующие тенденции позволяют предположить, что в дальнейшем инвестиции, учитывающие концепцию устойчивого развития, будут только расти.

Следовательно, компании, показывающие свою деятельность, направленную на сохранение и восстановление окружающей среды, поддержку низкоуглеродной экономики, получат стратегические конку- 
рентные преимущества в долгосрочной перспективе. Компаниям рекомендуют указывать следующие показатели, характеризующие их приверженность принципам зеленой экономики:

- процентную долю доходов оборота или процентную долю инвестиций в капитальные (CAPEX) и/или операционные (OPEX) расходы, связанные с деятельностью, приемлемой для таксономии, в отношении раскрытия информации, связанной с экологической составляющей;

- раскрытие в годовом отчете доходов, которые могут быть отнесены к низкоуглеродному производству, выделение соответствующих капитальных затрат как часть своих активов и обязательств;

- описание в отчете об устойчивом развитии как данное производство соответствует критериям таксономии и представление данных относительно «не нанесения значительного ущерба».

Таблица 4

«High confidence» mitigation subsectors

\begin{tabular}{|l|l|}
\hline $\begin{array}{c}\text { Виды экономической } \\
\text { Европейской классификации } \\
\text { видов экономической } \\
\text { деятельности (NACE) }\end{array}$ & \multicolumn{1}{|c|}{ Ключевые отрасли } \\
\hline $\begin{array}{l}\text { Сельское, лесное и рыбные } \\
\text { хозяйства }\end{array}$ & $\begin{array}{l}\text { Выращивание однолетних и многолетних культур } \\
\text { Лесозаготовка и лесопользование } \\
\text { Животноводство } \\
\text { Восстановление сельского хозяйства }\end{array}$ \\
\hline $\begin{array}{l}\text { Обрабатывающая промыш- } \\
\text { ленность }\end{array}$ & $\begin{array}{l}\text { Производство низкоуглеродных технологий, це- } \\
\text { мента, алюминия, чугуна и стали, водорода, дру- } \\
\text { гих органических и неорганических химических } \\
\text { веществ, удобрений и азотных соединений, } \\
\text { пластмасс }\end{array}$ \\
\hline $\begin{array}{l}\text { Электроснабжение, пода- } \\
\text { ча газа, пара, воздушное } \\
\text { кондиционирование }\end{array}$ & $\begin{array}{l}\text { Производство электроэнергии из: солнечной } \\
\text { энергии, ветра, океана, гидроэнергии, геотер- } \\
\text { мальной энергии, газа, биоэнергии } \\
\text { Передача и распределение электроэнергии } \\
\text { Хранение электроэнергии } \\
\text { Производство биомассы, биогаза и биотоплива, } \\
\text { Модернизация газотранспортных и газораспре- } \\
\text { делительных сетей } \\
\text { Центральное отопление /охлаждение } \\
\text { Монтаж и эксплуатация электрических тепло- } \\
\text { вых насосов }\end{array}$ \\
\hline
\end{tabular}


Окончание табл. 4

\begin{tabular}{|c|c|}
\hline $\begin{array}{c}\text { Виды экономической } \\
\text { деятельности согласно } \\
\text { Европейской классификации } \\
\text { видов экономической } \\
\text { деятельности (NACE) }\end{array}$ & Ключевые отрасли \\
\hline $\begin{array}{l}\text { Водоснабжение, канализацион- } \\
\text { ная система, контроль над } \\
\text { сбросом и распределением } \\
\text { отходов }\end{array}$ & $\begin{array}{l}\text { Сбор, обработка и распределение воды } \\
\text { Канализационная система } \\
\text { Сброс, обработка и удаление отходов, утилизация } \\
\text { отходов } \\
\text { Компостирование биологических отходов } \\
\text { Улавливание и утилизация свалочного газа }\end{array}$ \\
\hline Транспорт и складирование & $\begin{array}{l}\text { Пассажирский железнодорожный транспорт } \\
\text { (междугородний) } \\
\text { Грузовой железнодорожный транспорт } \\
\text { Общественный транспорт } \\
\text { Инфраструктура для транспорта с низким содер- } \\
\text { жанием углерода } \\
\text { Легковые и коммерческие автомобили } \\
\text { Грузовые перевозки автомобильным транспортом } \\
\text { Междугородние регулярные автомобильные пе- } \\
\text { ревозки } \\
\text { Внутренний пассажирский и грузовой водный } \\
\text { транспорт } \\
\text { Строительство водных объектов }\end{array}$ \\
\hline Информация и связь & $\begin{array}{l}\text { Обработка данных, хостинг и сопутствующая } \\
\text { деятельность для сокращения выбросов парни- } \\
\text { ковых газов }\end{array}$ \\
\hline Строительство и девелопмент & $\begin{array}{l}\text { Строительство новых зданий } \\
\text { Ремонт существующих зданий } \\
\text { Индивидуальные ремонтные работы, в т.ч. пред- } \\
\text { полагающие установку возобновляемых источ- } \\
\text { ников энергии } \\
\text { Покупка зданий }\end{array}$ \\
\hline
\end{tabular}

Источник: [2, 4].

TEG также разрабатывает Европейские стандарты зеленых облигаций [4], которые помогут развитию рынка зеленых облигаций, будут способствовать увеличению объемов финансирование в эко проекты.

Также TEG подготовил эталонные показатели (бенчмарки) в области изменения климата [4]. Они могут быть использованы участниками рынка для анализа эффективности стратегий в области ответ- 
ственного инвестирования с учетом ESG - факторов, а также для разработки финансовых продуктов и более эффективного распределения инвестиций.

Также TEG подготовил эталонные показатели (бенчмарки) в области изменения климата [4]. Они могут быть использованы участниками рынка для анализа эффективности стратегий в области ответственного инвестирования с учетом ESG - факторов, а также для разработки финансовых продуктов и более эффективного распределения инвестиций. Зеленые источники финансирования - это, прежде всего, зеленые облигации ${ }^{11}$, целевое назначение которых - финансирование экопроектов. Для подтверждения зеленого статуса проекта/ценной бумаги необходимо наличие определенных обязательных маркеров (см. рис.2). Рассмотрим принципиальное содержание/сущность данных маркеров (таблица 5).

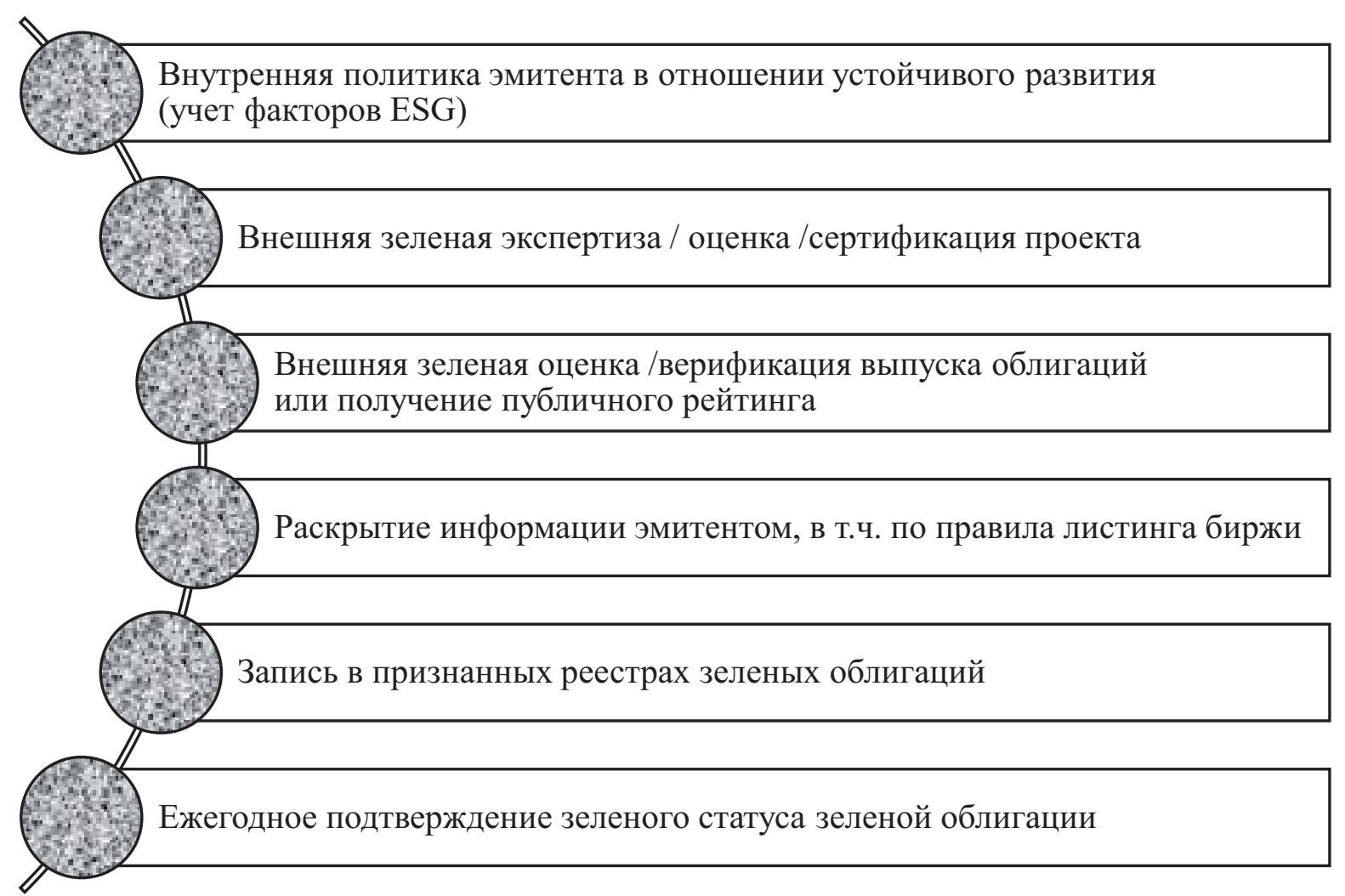

Рис. 2. Обязательные маркеры соответствия ценных бумаг/проектов принципам зеленых финансов.

Источник: составлено автором на основе [2, с.38]

${ }^{11}$ Обзор состояния рынка и тенденции его развития представлены в гл. 2 данного исследования. 
Таблица 5

Содержание обязательных маркеров соответствия ценных бумаг/проектов принципам зеленых финансов

\begin{tabular}{|c|c|c|}
\hline Маркер & Содержание & Документ \\
\hline $\begin{array}{l}\text { Внутренняя поли- } \\
\text { тика эмитента в от- } \\
\text { ношении устойчи- } \\
\text { вого развития }\end{array}$ & $\begin{array}{l}\text { Документ, в котором компания раскрывает } \\
\text { практику учета факторов ESG в управленче- } \\
\text { ской деятельности. На основе его анализа го- } \\
\text { товится верификационное заключение. }\end{array}$ & $\begin{array}{l}\text { Публичный } \\
\text { документ, } \\
\text { размещает- } \\
\text { ся на сайте } \\
\text { компании }\end{array}$ \\
\hline $\begin{array}{l}\text { Внешняя зеленая } \\
\text { экспертиза / оцен- } \\
\text { ка /сертификация } \\
\text { проекта }\end{array}$ & $\begin{array}{l}\text { Получение сертификатов как от государствен- } \\
\text { ных, так и негосударственных организаций } \\
\text { является обязательным. Экспертные органи- } \\
\text { зации должны быть аккредитованными. }\end{array}$ & $\begin{array}{l}\text { Сертификат } \\
\text { зеленого } \\
\text { бизнеса, } \\
\text { публичный } \\
\text { документ }\end{array}$ \\
\hline $\begin{array}{l}\text { Внешняя зеленая } \\
\text { оценка /верифи- } \\
\text { кация выпуска об- } \\
\text { лигаций или полу- } \\
\text { чение публичного } \\
\text { рейтинга }\end{array}$ & $\begin{array}{l}\text { Верификация выпуска облигаций или полу- } \\
\text { чение кредитного рейтинга (отдельного или } \\
\text { в составе кредитного) - получение внешней } \\
\text { оценки соответствия критериям зеленых об- } \\
\text { лигаций. }\end{array}$ & $\begin{array}{l}\text { Публичный } \\
\text { документ }\end{array}$ \\
\hline $\begin{array}{l}\text { Раскрытие инфор- } \\
\text { мации эмитентом, } \\
\text { в т.ч. по правилам } \\
\text { листинга биржи }\end{array}$ & $\begin{array}{l}\text { Эмитенты обязаны раскрывать информацию } \\
\text { в соответствии с правилами биржи. В } 2009 \text { г. } \\
\text { Генеральным секретарем ООН была создана } \\
\text { инициатива «Биржи за устойчивое развитие» } \\
\text { (Sustainable Stock Exchanges - SSE). Биржи } \\
\text { разрабатывают руководства по предоставле- } \\
\text { нию инвесторами информации о ESG, индек- } \\
\text { сы устойчивого развития, распространяют } \\
\text { практики ответственного инвестирования. } \\
\text { Московская биржа присоединилась к данной } \\
\text { инициативе в } 2019 \text { г. }\end{array}$ & $\begin{array}{l}\text { Публичный } \\
\text { документ }\end{array}$ \\
\hline $\begin{array}{l}\text { Запись в признан- } \\
\text { ных реестрах зеле- } \\
\text { ных облигаций }\end{array}$ & $\begin{array}{l}\text { К признанным реестрам зеленых облигаций } \\
\text { относятся такие организации как: Climate } \\
\text { Bonds Initiative, CBI; Международная ассо- } \\
\text { циаций рынков капитала, ICMA; агентство } \\
\text { Bloomberg; Environmental Finance Bonds } \\
\text { Database, др. }\end{array}$ & $\begin{array}{l}\text { Публичный } \\
\text { документ }\end{array}$ \\
\hline $\begin{array}{l}\text { Ежегодное под- } \\
\text { тверждение зеле- } \\
\text { ного статуса зеле- } \\
\text { ной облигации }\end{array}$ & $\begin{array}{l}\text { Выдают заключения о соответствии зеленых } \\
\text { облигаций, как правило, те же организации, } \\
\text { что и первичное подтверждение. }\end{array}$ & $\begin{array}{l}\text { Публичный } \\
\text { документ }\end{array}$ \\
\hline
\end{tabular}

Источник: составлено автором на основе [2]. 
Проведем анализ российской практики методологического обеспечения системы эко-финансов. Россия только начинает свой путь к развитию системы зеленого финансирования, но все основные элементы этой системы в России созданы и в 2018 году прошло первое размещение ценных бумаг, сертифицированных в соответствии с принципами зеленых финансов (компания «РСБ ХМАО» [5]), а с августа 2019 г. начал работать Сектор устойчивого развития на Московской бирже [6]. В России уже разработаны и внедрены основополагающие документы, формирующие стратегические перспективы развития эко-финансирования. К таким документам относятся:

- Национальные проекты (программы) по 12 направлениям, отвечающие целям устойчивого развития (ЦУР), а также план по модернизации магистральной инфраструктуры (таблица 6). Для рассматриваемой тематики исследования наиболее важным является национальный проект «Экология». Финансирование данного проекта предусматривает, помимо бюджетных ресурсов, привлечение с рынка 3,2 трлн. руб.

- Поручение Президента Российской Федерации № 31 от 18.12.2018 обеспечить запуск механизмы «зеленых» облигаций [7];

- подготовка добровольного национального обзора достижения целей устойчивого развития в рамках реализации Повестки дня в области устойчивого развития на период до 2030 г. к Политическому форуму по устойчивому развитию ООН в 2020 г. 07-16 июля [11];

- ратификация Россией Парижских соглашений в сентябре 2019 г.;

- подготовлен проект Федерального закона «О публичной нефинансовой отчетности» (подготовлен Минэкономразвития России) (не внесен в ГД ФС РФ), согласно которому «публичная нефинансовая отчетность - совокупность сведений и показателей, отражающих стратегию, цели, подходы к управлению и результаты деятельности организации в части социальной ответственности и устойчивого развития» [9];

- разработан проект ключевых показателей публичной нефинансовой отчетности [10], которые классифицированы по группам показателей: экономические, экологические, социальные, управленческие. Национальный регистр и библиотеку корпоративных нефинансовых отчетов ведет РСПП. На 11.04.2019 г. в библиотеке находится отчеты 176 компаний, всего зарегистрировано отчетов - 924 за период 20002017 гг. В их числе: экологические отчеты (ЭО) - 81, социальные отчеты $(\mathrm{CO})-326$, отчеты в области устойчивого развития (ОУР) - 314 , интегрированные отчеты - 176, отраслевые отчеты - 27 [12]. 


\section{Соответствие национальных проектов России и ЦУР}

\begin{tabular}{|c|c|}
\hline Цели устойчивого развития & Национальные проекты \\
\hline Цель 1. Ликвидация нищеты & $\begin{array}{l}\text { «Производительность труда и поддержка } \\
\text { занятости» }\end{array}$ \\
\hline Цель 2. Ликвидация голода & $\begin{array}{l}\text { «Производительность труда и поддержка } \\
\text { занятости», «Малое и среднее предпри- } \\
\text { нимательство и поддержка индивидуаль- } \\
\text { ной предпринимательской инициативы» }\end{array}$ \\
\hline $\begin{array}{l}\text { Цель 3. Хорошее здоровье и благопо- } \\
\text { лучие }\end{array}$ & «Здравоохранение» \\
\hline Цель 4. Качественное образование & «Образование», «Культура», «Наука» \\
\hline Цель 5. Гендерное равенство & $\begin{array}{l}\text { «Производительность труда и поддержка } \\
\text { занятости» }\end{array}$ \\
\hline Цель 6. Чистая вода и санитария & «Экология» \\
\hline Цель 7. Недорогая и чистая энергия & «Экология» \\
\hline $\begin{array}{l}\text { Цель 8. Достойная работа } \\
\text { и экономический рост }\end{array}$ & $\begin{array}{l}\text { «Малое и среднее предпринимательство } \\
\text { и поддержка индивидуальной предпри- } \\
\text { нимательской инициативы» }\end{array}$ \\
\hline $\begin{array}{l}\text { Цель 9. Индустриализация, иннова- } \\
\text { ции и инфраструктура }\end{array}$ & $\begin{array}{l}\text { «Наука», «Цифровая экономика Россий- } \\
\text { ской Федерации», Комплексный план } \\
\text { модернизации и расширения магистраль- } \\
\text { ной инфраструктуры }\end{array}$ \\
\hline Цель 10. Уменьшение неравенства & $\begin{array}{l}\text { «Малое и среднее предпринимательство } \\
\text { и поддержка индивидуальной предпри- } \\
\text { нимательской инициативы» }\end{array}$ \\
\hline $\begin{array}{l}\text { Цель 11. Устойчивые города } \\
\text { и населенные пункты }\end{array}$ & $\begin{array}{l}\text { «Безопасные и качественные автомобиль- } \\
\text { ные дороги», «Жильё и городская среда» }\end{array}$ \\
\hline $\begin{array}{l}\text { Цель 12. Ответственное потребление } \\
\text { и производство }\end{array}$ & «Экология» \\
\hline Цель 13. Борьба и изменением климата & «Экология» \\
\hline $\begin{array}{l}\text { Цель 14. Сохранение морских } \\
\text { экосистем }\end{array}$ & «Экология» \\
\hline Цель 15. Сохранение экосистем суши & «Экология» \\
\hline $\begin{array}{l}\text { Цель 16. Мир, правосудие и эффектив- } \\
\text { ные институты }\end{array}$ & «Образование», «Культура» \\
\hline $\begin{array}{l}\text { Цель 17. Партнерство в интересах } \\
\text { устойчивого развития }\end{array}$ & «Международная кооперация и экспорт» \\
\hline
\end{tabular}

Источник: составлено автором с использованием $[15,16]$. 
Подготовлены материалы с области обеспечения методологии зеленых финансов, в числе которых: результаты НИР НИФИ по исследованию рынка зеленых финансовых инструментов и возможностей их применения в российской экономике [13]; Концепция организации в России методологической системы по развитию зеленых финансовых инструментов и проектов ответственного инвестирования [2]; Диагностическая записка «Зеленые финансы: повестка дня для России», подготовленная членами рабочей группы по вопросам ответственного финансирования (ESG-finance), в т. ч. зеленого финансирования, при Экспертном совете по рынку долгосрочных инвестиций при Банке России с участием экспертов рынка соответствующих сфер деятельности и компетенций [14]; Диагностическая записка «Зеленые финансы: повестка дня для России», подготовленная членами рабочей группы по вопросам ответственного финансирования (ESG-finance), в т. ч. зеленого финансирования, при Экспертном совете по рынку долгосрочных инвестиций при Банке России с участием экспертов рынка соответствующих сфер деятельности и компетенций [17]; Рекомендации в области устойчивого развития и зеленых инвестиций, разработанные Национальной ассоциацией концессионеров и долгосрочный инвесторов в инфраструктуру НАКДИ [18]; Аналитическая записка «Зеленое финансирование» в России: создание возможностей для «зеленых» инвестиций, подготовленная специалистами Всемирного банка [19].

\section{Выводы}

Современная финансовая система все больше ориентируется на соблюдение принципов устойчивого экономического развития в своей деятельности. Факторами зеленой финансовой системы являются экологические, экономические и социальные факторы.

Особенностями российской системы эко-финансирования являются: «молодость» - данная система проходит в настоящее время этап становления, длительность правил разработки со стороны государства, неразработанность систем оценки рисков ESG-инвестирования, недостаточное влияние российских интересов на формирование глобальных правил.

Мировая практика накопила к настоящему временя достаточную институциональную базу в сфере эко-финансов, опыт применения которой необходимо адаптировать к российской практике. 
По нашему мнению, интересным для оценки рисков эко-проектов и деятельности компаний может быть использование показателей, характеризующих использование принципов зеленой экономики. Важным представляется внедрение обязательной публикации нефинансовых отчетов для компаний, позиционирующих себя как инновационные и использующие заемные источники финансирования для реализации эко-проектов.

В Россий разработаны стратегические документы, формирующие систему зеленой экономики и ее финансирования, подробный анализ нормативно-правовой базы и информационного обеспечения данной сферы представлен далее в работе в п.1.2.

\section{2. Нормативно-информационное обеспечение устойчивого развития российских регионов в области зеленой экономики ${ }^{12}$}

Важность рассмотрения экологических проблем как отдельных регионов, так и мира в целом, не вызывает сомнения, поскольку именно качество окружающей среды формирует качество жизни населения. Внимание к проблемам экологии, их взаимосвязь и взаимозависимость с экономическими проблемами привело к формированию концепции устойчивого экономического роста и разработке теории «зеленого роста». Данные концепции и теория в настоящее время активно обсуждаются и внедряются в практику мировой и региональных экономик. Они являются основой для принятия политических, экономических, финансовых, технических решений как на межгосударственном уровне, на уровне отдельных государств, регионов, компаний, каждого человека в отдельности. Принципы «зеленой» экономики были представлены Программой ООН по окружающей среде (ЮНЕП - United Nations Environment Programme) в докладе «Глобальный зеленый новый курс» в 2009 г. [21]. 2009 год был годом мирового финансового кризиса и именно кризис привел к осознанию невозможности дальнейшего развития по модели докризисного экономического роста. Это привело к пониманию и разработке новых целей мировой экономики, таких как: 1) сохранение и создание новых рабочих мест, защита беднейших слоев населения (краткосрочная пер спектива), 2) достижение «Целей развития тысячелетия»»,

\footnotetext{
${ }^{12}$ Материалы параграфа использованы в статье автора [20].
} 
к которым относятся ликвидация бедности, уменьшение выбросов углерода, восстановление экосистем, обеспечение стабильного экономического развития. В программе были определены ключевые направления и принципы инвестирования и посткризисной экономике, такие как: стимулирование инвестиций в безотходные технологии, регенерация инфраструктуры окружающей среды (леса, водные ресурсы, воздух, почвы). Устойчивый экономический рост должен обеспечиваться за счет воссоздания и развития «зеленой» инфраструктуры и повышения качества жизни населения. Таким образом концепция устойчивого экономического развития связывает повышение благосостояния людей со снижением экологических рисков, декларирует экономический рост при одновременном улучшении /неухудшении окружающей среды.

Решение глобальных экологических проблем на данном этапе зависит от разработки соглашений и принятии мер на межгосударственном уровне. К базовому соглашению, которое определяет принципы международного консенсуса в сфере контроля за изменениями климата, относится Рамочная конвенция ООН по изменению климата [22], в которой сформулированы направления, принципы и меры по смягчению климатических изменений и их последствий.

Продолжением и развитием Рамочного соглашения явился Киотский протокол (Киотский протокол к Рамочной конвенции Организации Объединенных Наций об изменении климата [23]), принятый 159 государствами 11 декабря 1997 г. и вступивший в силу 16 февраля 2005 г. Завершение первого этапа (базового обязательства) протокола завершилось 31 декабря 2012 г. В протоколе зафиксировано намерение снизить выбросы парниковых газов в атмосферу на 5,2\% [24] в период 2008-2012 гг. по сравнению с уровнем 1990 г. Достичь такого результата (и вступить в силу Киотский договор) должны были выполнение следующих условий: подписание договора не менее 55 государствами и к «протоколу должны были присоединиться государства, на долю которых в совокупности в 1990 г. приходилось не менее 55\% общих выбросов парниковых газов. К сентябрю 2004 г. документ ратифицировали 124 государства, однако их суммарный объем эмиссий $\mathrm{CO}_{2}$ не превышал 44\%. Судьба документа зависела от России, которая на тот момент занимала третье место в мире после США и Китая по объему выбросов парниковых газов. Документ вступил в силу в феврале 2005 г. лишь после присоединения к нему РФ [24]. 
Результатом первого этапа явилось создание действующего механизма мирового уровня по охране окружающей среды, основанного на рыночных методах. Вместе с тем реализация Киотского протокола выявила и его сложности: Китай и Индия отказались брать на себя обязательства по его исполнению. США заявили о своем неучастии до 2013 года. Россия подписала договор в 1999 г., но ратифицировала только в ноябре 2004 г. [25].

В декабре 2012 года был утвержден второй период Киотского протокола (Киото-2), период действия которого с 01 января 2013 г. до 2020 г. Киото-2 приняли такие страны как Евросоюз, Австралия, Казахстан, Украина, Белоруссия, Норвегия, Швейцария, Исландия, Лихтенштейн, Монако.

Россия, Япония, Новая Зеландия и Канада отказались участвовать во втором этапе [25]. Одной из причин отрицательной позиции России стало изменение механизмов соглашения, в частности, отмена торговли эмиссионными сертификатами с 2013 года, поскольку, как отмечает «Frankfurter Allgemeine», «эта продажа лишь увеличила выброс парниковых газов в мировом масштабе» [26]. Также «Frankfurter Allgemeine» отмечает, что торговля квотами «привлекла в страну (Россию - А.) инвестиции на сумму в почти 600 миллионов долларов» [26].

Оценивая эффективность Киотского договора, следует отметить, что к договору присоединились страны, которые обеспечивают в совокупности только 15\% [26] выбрасываемых в атмосферу вредных парниковых газов.

12 декабря 2015 г. подписано Парижское соглашение, которое провозглашает своей целью развитие усилий по снижению выбросов парниковых газов и являются развитием Рамочного соглашения и Киотского протокола. Соглашение получило поддержку 196 стран. Оно предусматривает, что к 2020 г. стороны соглашения должны представить и опубликовать национальные стратегии долговременного развития, направленные на достижение целевых показателей выбросов парниковых газов, оговоренные в Парижском соглашении, а также разработать механизмы контроля и обмена опытом, методику адаптации, механизмы поддержки и консультирования развивающихся стран [27].

По данным ООН «по состоянию на апрель 2018 года, Парижское соглашение по климату было ратифицировано 175 сторонами и 168 сторон предоставило свои национальные планы Секретариату РКООНИК» [28]. Участники соглашения берут на себя обязательства принять все воз- 
можные меры для недопущения роста средней температуры Земля более, чем на $2^{\circ} \mathrm{C}$, а с учетом важности проблемы - ограничить рост $1,5^{\circ} \mathrm{C}[28]$. В рамках соглашения развитые страны выделяют на научные исследования в области низкоуглеродных источников энергии 100 млрд. долл., после 2015 года эта сумма может увеличиться [25].

Россия активно участвует в разработке и реализации международных соглашений по снижению антропогенной нагрузке на окружающую среду и противодействию негативному изменению климата. Еще в 1996 г. был принят Указ Президента Российской Федерации № 440 от 01.04.1996 г. «О концепции перехода Российской Федерации к устойчивому развитию» [29], а в 2002 г. вступил в действие Ф3 «Об охране окружающей среды» [30], который является базовым документом в рассматриваемой области.

Обязательства России по Парижскому соглашению предусматривают снижение выбросов парниковых газов к 2010 г. до 75\% от уровня 1990 г. В 2016 г. объем выбросов парниковых газов российской экономикой по данным Международного агентства составил 1 438,6 млн т, это 66,49\% от уровня 1990 г. (от 2 163,5 млн. т) [31]. То есть достигнуто существенное снижение выбросов парниковых газов. Но исследователи отмечают, что при существующем уровне углеродоемкости российской экономики, гораздо более значительном, чем у развитых экономик мира, при сохранении данного показателя на уровне 2015 г. и умеренного роста ВВП, к 2030 г. объем выбросов может значительно превысить уровень 1990 г. [32, 33, с.98]. Таким образом, при отсутствии прогресса в развитии программ энергоэффективности и энергосберегающих технологий, России сложно будет выполнить обязательства Парижского соглашения.

Выполнение Россией Парижского соглашения связано с рядом сложностей, т.к. в России существует значительное количество крупных промышленных городов, в которых сосредоточены крупнейшие металлургические, химические, добывающие производства (это такие города как Норильск, Череповец, Магнитогорск и др.) и существует технические и технологические ограничения по снижению вредных веществ.

Россия принимает важные шаги, направленные на ратификацию Парижских соглашений и подготовку условий для их выполнения. Так на законодательном уровне принят «План реализации комплекса мер по совершенствованию государственного регулирования выбросов 
парниковых газов и подготовки к ратификации Парижского соглашения, принятого 12 декабря 2015 г. 21-й сессией Конференции Сторон Рамочной конвенции Организации Объединенных Наций об изменении климата», который был утвержден распоряжением Правительства Российской Федерации от 3 ноября 2016 г. N 2344-р [34]. План предусматривает оценку социально-экономических последствий ратификации Парижского соглашения, на основе которой готовится доклад Президенту Российской Федерации о целесообразности ратификации Парижского соглашения. Доклад был представлен Минприроды России, которое «подготовило и внесло 28 февраля 2019 г. в Правительство РФ предложения с обоснованием целесообразности ратификации» [35]. Процесс обсуждения завершился в конце 2019 года к началу 25-й сессии Конференции Сторон РКИК ООН.

Ряд экспертов возражают против быстрой и неаргументированной ратификации договора, отмечая «недоказанность антропогенного влияния на изменение климата», но бизнес-сообщество в лице РСПП решило не возражать против ратификации Парижских соглашений, но при этом продвигать свой вариант концепции углеродного регулирования, в письме Минприроды РСПП настаивает, что «в РФ не должны реализовываться модели углеродного регулирования, связанные с дополнительной финансовой нагрузкой на базовые отрасли экономики, поскольку это приведет к снижению их конкурентоспособности и росту затрат промышленности и населения», а само регулирование «должно носить прозрачный, объективный и необременительный характер для российских компаний, стимулировать развитие отечественной экономики» [36].

План предусматривает разработку концепции и механизмов регулирования выбросов парниковых газов в Российской Федерации, в том числе разработку мер финансовой поддержки и стимулирования ограничений выбросов таких газов, в частности предусмотрено: подготовка проекта плана мероприятий по реализации установленной указом Президента Российской Федерации цели ограничения выбросов парниковых газов к 2030 году; подготовка проекта федерального закона о государственном регулировании выбросов парниковых газов; разработку проекта стратегии долгосрочного развития с низким уровнем выбросов парниковых газов до 2050 года; разработку плана по сокращению выбросов парниковых газов в результате обезлесения и деградации лесов, усиления мер по сохранению, устойчивому управлению 
и увеличению накопления углерода в лесах; разработку модели государственного регулирования выбросов парниковых газов в Российской Федерации; разработку проекта национального плана адаптации к неблагоприятным изменениям климата; подготовку предложений об участии в международных финансовых механизмах по оказанию помощи развивающимся странам в смягчении последствий изменения климата и адаптации [34].

План и документы разрабатываются и проходят экспертизу согласно принятому документу. Так в январе 2018 г. комиссия по законопроектной деятельности одобрила проект Федерального закона «О парниковых газах», до настоящего времени законопроект не вступил в силу [35]. Целью закона является «создание условий для сокращения выбросов парниковых газов с учетом необходимости обеспечения экономического развития Российской Федерации на устойчивой основе и в соответствии с международными обязательствами» [35].

Проект закона определяет основные понятия в данной области, среди которых «парниковые газы», «выбросы парниковых газов», «инвентаризация выбросов парниковых газов», «государственный учет выбросов парниковых газов», «целевой показатель выбросов парниковых газов» и др. В Проекте определены Полномочия федеральных органов исполнительной власти в сфере государственного регулирования выбросов парниковых газов, среди которых: установление и распределение разрешений на выбросы парниковых газов хозяйствующим субъектам; утверждение методик количественного определения выбросов парниковых газов хозяйствующими субъектами; утверждение требований к проектам, направленным на сокращение выбросов и (или) увеличение поглощения парниковых газов; проведение государственного учета выбросов и поглощений парниковых газов [35, ст.5]. Законом предусмотрена организация государственный учета парниковых газов, в т.ч. мониторинг и отчетность о выбросах парниковых газов [35, ст.7]. Важным аспектом закона является разработка механизмов экономического стимулирования деятельности по сокращению выбросов парниковых газов и (или) увеличению их поглощения $[35$, ст.11], в которой предусматриваются такие меры как применение ускоренной амортизации основных производственных фондов, предназначенных для деятельности по сокращению выбросов парниковых газов и (или) увеличению их поглощения, а также предоставление налоговых льгот. 
Минприроды России активно разрабатывает нормативные акты, направленные на реализацию Парижских соглашений, среди которых: в 2015 г. утверждены методические указания и руководство по количественному определению объемов выбросов парниковых газов организациями, осуществляющими хозяйственную и иную деятельность в Российской Федерации [36]; в 2018 г. приняты такие документы как: Приказ Минприроды России от 11.10.2018 N 509 «Об утверждении формы декларации о воздействии на окружающую среду и порядка ее заполнения, в том числе в форме электронного документа, подписанного усиленной квалифицированной электронной подписью» [37]; Приказ Минприроды России от 11.10.2018 N 510 «Об утверждении формы заявки на получение комплексного экологического разрешения и формы комплексного экологического разрешения» [38].

Обсуждение и ратификация Парижского соглашения в России завершилось в 2019 г. - к 25-ой сессии конференции Рамочной конвенции ООН об изменении климата [39]. 23 сентября 2019 г., в день проведения саммита $\mathrm{OOH}$ по борьбе с климатическими изменениями, премьер-министр РФ Д.А. Медведев подписал постановление правительства, связанное с принятием Россией Парижского соглашения по климату [40]. Таким образом Россия присоединилась к Парижским климатическим соглашениям 2015 г. и «стала одним из последних крупных эмитентов парниковых газов, ставших полноправным участником нового климатического договора, пришедшего на смену Киотскому протоколу» [41]. Таким образом Россия активно участвует в международных процессах регулирования и реализации соглашений, направленных на снижение антропогенного вредного воздействия на окружающую среду. Но при этом существуют риски «трансформации традиционных нефтегазовых экспортных рынков России» [33, с. 101], а также различие в оценках выгод и издержек для российской экономики при реализации Парижских соглашений. Исследователи [33] опасаются следующих негативных последствий для российской экономики:

1) возможный рост себестоимости углеродного топлива, а также продукции отраслей, в затратах которых высока доля статьи «топливо и энергия», таких как металлургия, производство удобрений, цемента ввиду введения финансовых и налоговых обременений.

Отметим, что по запасам угля, который как источник энергии признан оказывающим вредное воздействие на окружающую среду [42], Россия занимает второе место в мире (см. таблицу 7). «Сжигание угля 
ведет к образованию больших количеств двуокиси углерода, серы, ртути и других вредных веществ. В этом отношении уголь - самый худший из всех видов органического топлива», - отмечают специалисты НИИ малотоннажных химических продуктов и реактивов Уфимского государственного нефтяного технического университета [43, с.24]. Также по данным аналитиков независимой информационно-консалтинговой компании Enerdata, в 2017 году «интенсивность выбросов $\mathrm{CO}_{2}$ в России была на 80\% выше среднего показателя в мире» [44].

Таблица 7

Страны мира с крупнейшими запасами угля

\begin{tabular}{|c|c|}
\hline $\begin{array}{c}\text { 3апасы } \\
\text { угля, } \\
\text { млрд. т }\end{array}$ & \multicolumn{1}{c|}{ Характеристика } \\
\hline 237,3 & $\begin{array}{l}\text { СШаже } \\
\text { (от 450 м на Западе США и до 900 м в Аппалачском бассейне). Место- } \\
\text { расположения часто имеют рядом крупного потребителя (ТЭЦ), что } \\
\text { обеспечивает экономическую эффективность добычи. } \\
\text { Более 85\% всех запасов угля Соединенных Штатов сосредоточены } \\
\text { в семи направлениях: Кентукки, Иллинойс, Вайоминг, Пенсильвания, } \\
\text { Колорадо, Алабама, Техас. США находится на 1 месте как по показа- } \\
\text { телям запасов, так и добычи угля. }\end{array}$ \\
\hline 157 & $\begin{array}{l}\text { Это приближенные данные, поскольку недостаточно разведаны воз- } \\
\text { можные запасы ресурса. Наиболее активно разрабатываются следую- } \\
\text { щие месторождения: Печорское, Канско-Аченское, Кузнецкое, Южно- } \\
\text { Якутское. Много месторождений, разработка которых экономически } \\
\text { неэффективна ввиду неблагоприятного экономико-географического } \\
\text { расположения. 70\% запасов углей - высокого качества. Запасов бурого } \\
\text { угля больше, чем каменного. По оценкам экспертов Россия имеет треть } \\
\text { мировых запасов угля (4 трлн. т). }\end{array}$ \\
\hline 114,5 & $\begin{array}{l}\text { Китай } \\
\text { Не все запасы угля разведаны, по оценкам, общее количество углей } \\
\text { может составлять 781 млрд. т. 97\% запасов - каменные угли. Крупней- } \\
\text { ший угольный бассейн - Шаньсинский. } \\
\text { Коксы располагаются в бассейнах Великой Китайской равнины, Янц- } \\
\text { зы, Ганьзян, Датун, Хэган-Шуанъяшань и прочих точках. 90\% добы- } \\
\text { ваемых углей потребляется энергетической промышленностью. }\end{array}$ \\
\hline
\end{tabular}


Окончание табл. 7

\begin{tabular}{|c|c|}
\hline $\begin{array}{c}\text { Запасы } \\
\text { угля, } \\
\text { млрд. т }\end{array}$ & Характеристика \\
\hline \multicolumn{2}{|r|}{ Австралия } \\
\hline 76,4 & $\begin{array}{l}\text { По оценкам, запасов угля хватит для разработки на } 240 \text { лет. Наиболее } \\
\text { крупные месторождения находятся на } \\
\text { Востоке материка. Имеются крупные запасы коксующихся углей высо- } \\
\text { кого качества, которые располагаются преимущественно в штатах Но- } \\
\text { вый Южный Уэльс и Квинсленд. Запасы бурого угля размещены } \\
\text { на юго-востоке страны. Более } 80 \% \text { угля идет на обслуживание электро- } \\
\text { энергетики. Это вдвое больше мирового показателя. Местные ТЭС от- } \\
\text { личаются высокой экологичностью. }\end{array}$ \\
\hline \multicolumn{2}{|r|}{ Индия } \\
\hline 60,6 & $\begin{array}{l}\text { Индия располагает 9\% запасов угля. Он является основным источни- } \\
\text { ком сырья для производства энергии. } \\
\text { Наиболее важные месторождения расположены на северо-восто- } \\
\text { ке страны. Качество угля низкое. Используется в электроэнергетике } \\
\text { (преимущественно), а также в металлургии, цементной и транспорт- } \\
\text { ной промышленностях, в быту. }\end{array}$ \\
\hline \multicolumn{2}{|r|}{ Германия } \\
\hline 40,7 & $\begin{array}{l}\text { Уголь высокого качества. Наибольшее количество запасов сосредото- } \\
\text { чено на территории федеральных земель Северный Рейн-Вестфалия } \\
\text { и Саар, Саксонии, Бранденбурге, а также Северной Рейн-Вестфалии. } \\
\text { В настоящее время добыча угля нерентабельна, существуют дотации } \\
\text { государства. }\end{array}$ \\
\hline \multicolumn{2}{|r|}{ Украина } \\
\hline 33,9 & $\begin{array}{l}\text { Обладает 4\% мировых запасов угля. В основном запасы каменного } \\
\text { угля сосредоточены в Донецком и Львовско-Волынском бассейнах, бу- } \\
\text { рого - в Днепровском. При этом 98\% каменного угля находится в До- } \\
\text { ценком бассейне, } 2 \% \text { - во Львовско-Волынском. Уголь расположен } \\
\text { на достаточно большой глубине (1-1,3 км) и содержит газ, что делает } \\
\text { добычу опасной из-за повышенной угрозы взрыва. }\end{array}$ \\
\hline
\end{tabular}

Источник: составлено автором по [45].

Несмотря на высокие экологические риски применения угля, как отмечают эксперты, «в дальнейшем уголь по-прежнему будет одним из основных энергоносителей в топливно-энергетическом балансе восточных регионов (России - A.). Наиболее перспективным с позиций экономики и экологии представляется создание промышленных 
кластеров на базе месторождений угля» [46, с.155]. В связи с этим особое значение необходимо уделять разработке инновационных экологических проектов, способных минимизировать негативное влияние на окружающую среду, так как «экологические аспекты широкомасштабного развития угледобычи для строительства электростанций требуют основательной проработки» [46, с.162].

При введении платы за выбросы парниковых газов необходимо просчитывать последствия для развития российских отраслей. Эксперты предупреждают, что, если выплаты составят более 1,0\% ВВП, это нанесет значительный ущерб экономике [47]. Такая ситуация касается стран, в структуре экспорта преобладают продукция ТЭК, черные и цветные металлы, крупнотоннажная химическая продукция, цемент и т.п., а энергетика основана на использовании ископаемого топлива, и к таким странам относится Россия (см. таблицу 8). Так, доля экспорта минеральных продуктов не опускалась за 10 лет ниже 59,2\% (2016 г.), далее последовал рост: 60,4\% - в 2017 г., $64,9 \%$ - в 2018 г.

Для рассматриваемых сценариев ввода углеводородного сбора расчеты показывают следующее: при ставке 15 долл. США / т экв. $\mathrm{CO}_{2}$ ежегодные выплаты составят 42 млрд долл. или 3,2-4,1\% ВВП; при ставке 35 долл. США / т экв. $\mathrm{CO}_{2}$ объем выплат составит 7,5-9\% ВВП. Наиболее серьёзный ущерб составит для таких отраслей как нефтегазовая отрасль, электро- и теплогенерация, транспорт, АПК, металлургия, производство азотных удобрений и цемента. Оценка ущерба: до 75\% выручки, и до 615\% EBITDA [47, с.8].

2) ведущчие страны мира значительное внимание уделяют развитию альтернативное энергетики и увеличению доли возобновляемых источников энергии (ВИЭ) при производстве новых мощностей. Для стран, зависящих от импорта топлива, стран, с низкой себестоимостью производства ВИЭ, такая стратегия экономически оправдана и целесообразна.

Так, доля возобновляемых источников в производстве электричества в 2017 г. в Норвегии составляла 97,6\%, в Колумбии - 86,8\%, в Новой Зеландии - 81,4\%, в Бразилии - 79,7\%, в Канаде - 64,7\%, в Швеции - 57,5\% [49]. В странах с наибольшими запасами угля эта доля гораздо ниже: так в 2017 г. в США она составила 17,66\%, в России $17,5 \%$, в Китае - 25,97\% , в Австралии - 14,95\%, в Индии - 16,29\%, в Германии - 33,98\%, в Украине - 7,86\% (см. таблицу 9). 
Глава 1

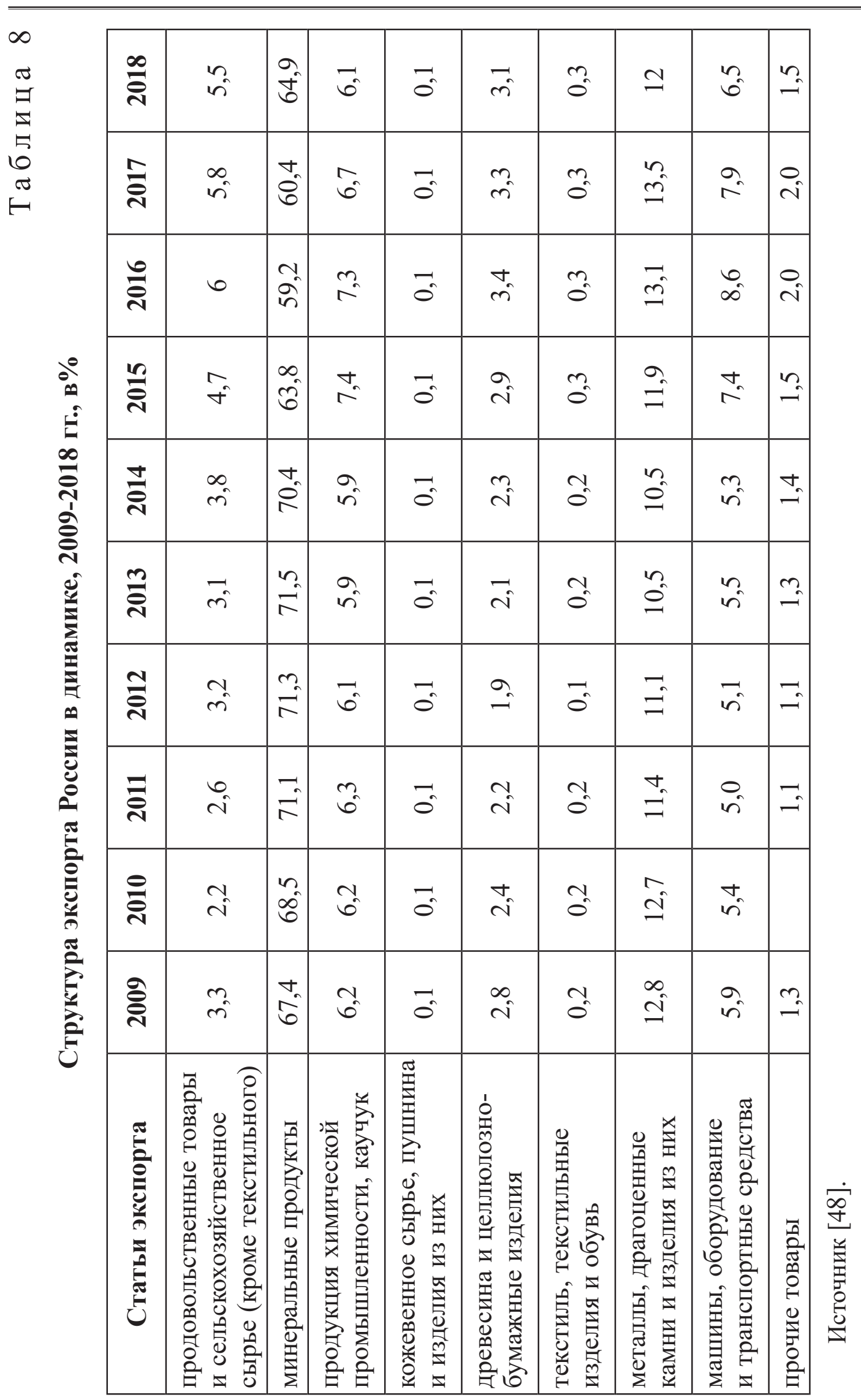




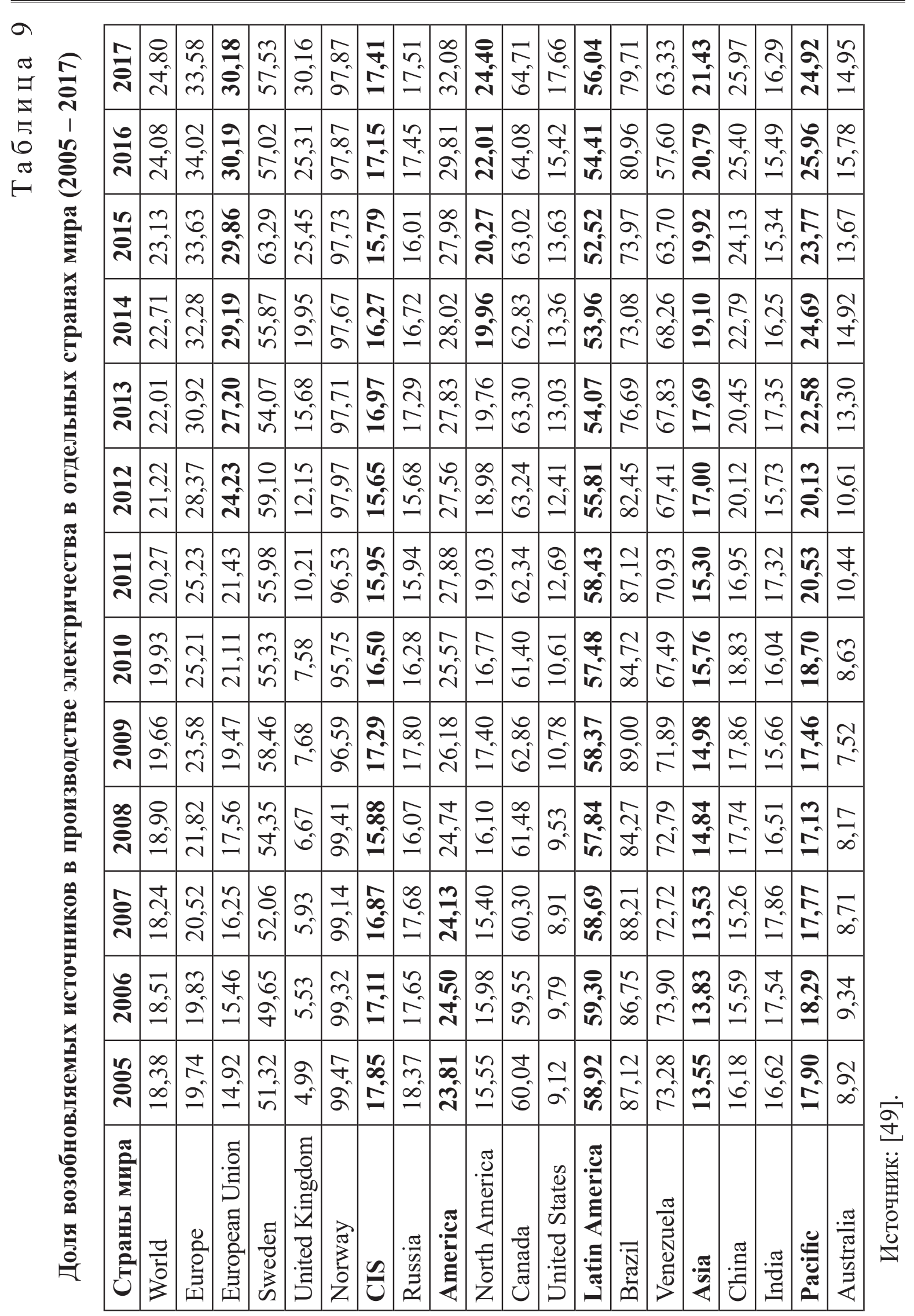


Отметим, что в российской экономике доля возобновляемых источников в производстве электричества в России менялась незначительно: 15,3\% в 1990 г. и 17,2\% в 2018 г. (см. рис. 3). Снижение затрат и политика стимулирования ВИЭ в развитых и развивающихся странах способствует их развитию.

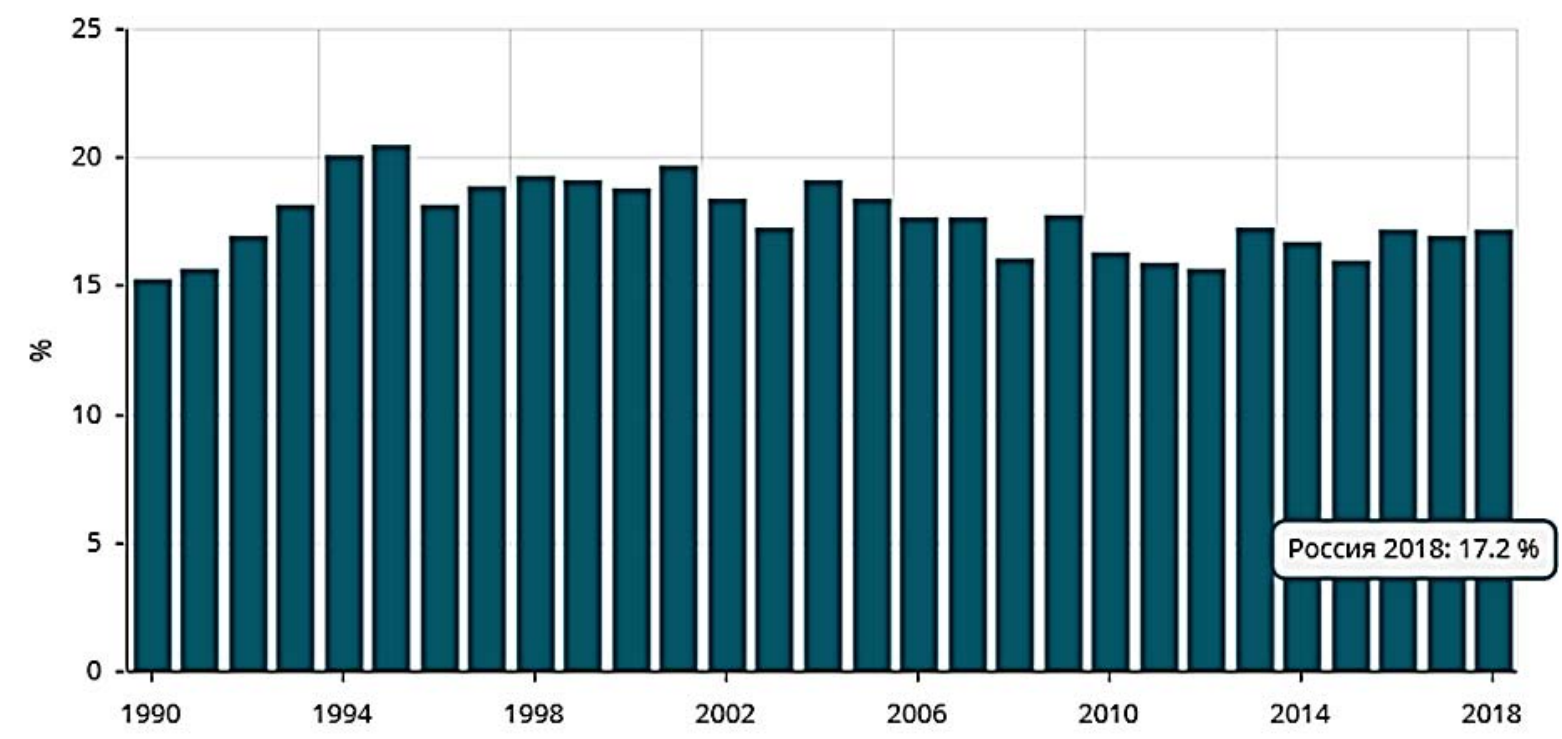

Рис. 3 Доля возобновляемых источников в производстве электричества в России (1990-2018). Источник: [49].

«Солнечные станции отвечают за 20\% дополнительной выработки электроэнергии в 2017 году, а ветряные - за 30\%. Возобновляемые источники энергии теперь покрывают $1 / 3$ энергетической потребности в Европе, 1/4 в Китае и 1/6 в Соединенных Штатах, Индии и Японии», - отмечают независимые эксперты из Enerdata [49]. В России ввиду высоких затрат на ВИЭ, особенностей климата, отсутствию комплексной поддержки ВИЭ развитие ВИЭ в ближайшие 5-7 лет ожидается, по оценкам специалистов, только в отдельных районах [33, с.101].

3) Увеличение рисков технологического отставания российской экономики. Парижские соглашения стимулируют развитие инновационных технологических инноваций в области «зеленой экономике», открывают новые возможности для компаний-лидеров в данных сфеpax. С учетом технологического отставания России даже в традиционных технологических направлениях [50], риски отставания российской экономики только углубляются. Внедрение экологических сбо- 
ров, штрафов и т.п. мер необходимо обосновывать экономически, поскольку может привести к росту затрат добывающих компаний и снижению их конкурентоспособности, следовательно, снижению инвестиционного и кредитного рейтингов. Декларируемые в российских нормативных актах разработка мер поддержки и стимулирования экологически ответственных производств должны быть обоснованными и найти свое воплощение в практической деятельности.

4) Высокая неопределенность в понимании механизмов и направлений дальнейшей реализации Парижского соглашения, связанная с таким факторами как: а) отсутствие четкой позиции ключевых игроков (таких как США), б) активная роль бизнес-сообществ, которые обращают внимание на риски роста издержек бизнеса, потерю конкурентоспособности, сокращение числа рабочих мест и доходов работников; в) наличие антироссийских санкций, из-за которых оказались «замороженными» многие экологические проекты, реализуемые Россией совместно с Всемирным банком [33, с.101]. Как пример таких рисков отметим, что оборудование для СЭС и ВЭС не производится в России в достаточных объемах [47, с.10], следовательно при активном развитии ВИЭ выгоды получат зарубежные компании, а также возможен отказ от сервисных работ при введении каких-либо антироссийских санкций.

Механизмы реализации Парижских соглашений можно разделить на две группы:

A) Жесткие. Они включают следующие направления и требуют для реализации значительных инвестиций $[47$, с.5]: введение углеродного сбора, организация систем торговли квотами; строительство «безуглеродных» станций (СЭС, ВЭС, АЭС, ГЭС); установка оборудования по улавливанию и хранению $\mathrm{CO}_{2}$.

Следует учитывать, что жесткие меры окажут существенное влияние на развитие целых отраслей экономики, которые для России являются стратегическими. Отдельные специалисты считают, что «природоохранная повестка может активно использоваться в международной конкурентной борьбе» [51, с.13].

Б) Мягкие. Данные меры не требуют значительных финансовых затрат и отличаются быстрыми сроками окупаемости. К ним относят: повышение энергоэффективности и энергосбережения в российской экономике; развитие комбинированной выработки электро- и теплоэнергии на ТЭЦ; стимулирование лесовосстановительных работ; меро- 
приятия по ограничению выбросов парниковых газов от АПК; информирование, образование; адаптация методик учета парниковых газов к российским условиям.

\section{Выводы}

Российская Федерация активно участвует в реализации международных соглашений по предотвращению изменений климата и снижению антропогенного воздействия на окружающую среду. К настоящему времени разработаны такие основополагающие нормативные акты в области охраны окружающей среды в которых определены основные принципы охраны окружающей среды, предусматривается разработка концепции и механизмов регулирования выбросов парниковых газов в Российской Федерации, а также механизмов экономического стимулирования деятельности по сокращению выбросов парниковых газов и (или) увеличению их поглощения.

Вместе с тем эксперты предупреждают о рисках быстрой и неаргументированной ратификации Парижского договора для российской экономики, о возможных негативных последствиях для ряда отраслей при введении жестких мер, а именно:

- увеличение себестоимости углеродного топлива и роста затрат на производство в отраслях, в которых высока доля затрат на топливо и энергию (металлургия, производство удобрений, цементная отрасль);

- ограниченную экономическую эффективность развития альтернативной электроэнергетики, возобновляемых источников энергии;

- увеличение рисков технологического отставания российской экономики;

- высокая неопределенность в понимании механизмов и направлений дальнейшего развития Парижских соглашений

«Мягкие» меры реализации Парижских соглашений могут, напротив, одновременно привести к снижению антропогенной нагрузки на окружающую среду и улучшить экономические показатели Российской экономики. Так, российская экономика в настоящее время характеризуется высокой энергоемкостью экономики. Правительством Российской Федерации от 15.04.2014 г. № 316 утверждена государственная программа «Экономическое развитие и инновационная экономика» [52], одной из подпрограмм которой является программа «Энергосбережение и повышение экономической эффективности» [53], целевое назначение которой - «снижение энергоемкости экономики Российской Федера- 
ции» [53]. В настоящее время действует редакция программы от 29.03.2019 г. Задачами подпрограммы являются: развитие институциональной среды как комплекса правовых, организационно-управленческих, финансовых и материально-технических условий, стимулирующих и обеспечивающих возникновение и реализацию инициатив и мероприятий в области энергосбережения и повышения энергетической эффективности; стимулирование привлечения внебюджетных инвестиций в реализацию мероприятий (проектов) в области энергосбережения и повышения энергетической эффективности; формирование среды комплексной информационной поддержки энергосбережения и повышения энергетической эффективности на всех уровнях структур государственного управления и общества [53]. Объем бюджетных ассигнований на реализацию подпрограммы за счет средств федерального бюджета составляет 389 293,2 тыс. рублей, в том числе: «на 2019 год 62 011,6 тыс. рублей; на 2020 год - 63 882,4 тыс. рублей; на 2021 год 65 849,8 тыс. рублей; на 2022 год - 65 849,8 тыс. рублей; на 2023 год 65 849,8 тыс. рублей; на 2024 год - 65 849,8 тыс. рублей» [53]. Стимулирование внедрения энергосберегающих технологий позволит уменьшить нагрузку на окружающую среду и повысить конкурентоспособность российской экономики.

Спецификой российского варианта развития экологических программ является развитие лесного хозяйства с целью повышения поглощения парниковых газов. Российские леса составляют около $20 \%$ всех лесов мира и вносят значительный вклад в сокращение выбросов парниковых газов. Необходимо проводить рациональную государственную политику, направленную контроль за их вырубкой и восстановление лесов. Специалисты отмечают необходимость корректировки действующих методик учета парниковых газов, которые не учитывают поглощающий эффект российских лесов [47, с.]. Также необходимо учитывать роль океана в поглощении парниковых газов: согласно исследованиям, мировой океан поглощает около $30 \%$ парниковых газов. Поэтому необходимо учитывать в методиках учет поглощения парниковых газов в экономической зоне или территориальных водах России. Таким образом в стратегии развития «зеленой экономики» в России необходимо учитывать специфику развития всей экономики России, особенностей ее климата, наличие и качество природных ресурсов, качество существующей технологической платформы, внешние и внутренние политические факторы. 


\section{ГЛАВА 2. АНАЛИЗ МЕТОДОВ И ИНСТРУМЕНТОВ ФИНАНСИРОВАНИЯ ПРОЕКТОВ ЗЕЛЕНОЙ ЭКОНОМИКИ}

\section{1. Анализ долгосрочных инструментов финансирования проектов зеленой экономики (зарубежный опыт) ${ }^{13}$}

Значимость и приоритетность экологических проектов для современной экономики декларируется в международных и российских нормативных актах. Так в Указе Президента Российской Федерации «О национальных целях и стратегических задачах развития Российской Федерации на период до 2024 года» сказано о необходимости достижения следующих целей и показателей в сфере экологии:

« - эффективное обращение с отходами производства и потребления, включая ликвидацию всех выявленных на 1 января 2018 г. несанкционированных свалок в границах городов;

- кардинальное снижение уровня загрязнения атмосферного воздуха в крупных промышленных центрах, в том числе уменьшение не менее чем на 20 процентов совокупного объёма выбросов загрязняющих веществ в атмосферный воздух в наиболее загрязнённых городах;

- повышение качества питьевой воды для населения, в том числе для жителей населённых пунктов, не оборудованных современными системами централизованного водоснабжения;

- экологическое оздоровление водных объектов, включая реку Волгу, и сохранение уникальных водных систем, включая озёра Байкал и Телецкое;

- сохранение биологического разнообразия, в том числе посредством создания не менее 24 новых особо охраняемых природных территорий» [55].

Решение данных задач требует реализации инвестиционных и инновационных экологических проектов и формирование эффективной системы финансирования таких проектов. Финансирование экологических проектов может осуществляться с использованием различных финансовых инструментов, которые широко используются в инвести-

${ }^{13}[54$, п.3.1, испр. и перераб.] 
ционном процессе. Выбор того или иного источника финансирования зависит от многих факторов (см. табл. 10), в том числе требует учета особенностей экологических проектов.

Таблица 10

\section{Факторы формирования источников финансирования экологических проектов}

\begin{tabular}{|c|c|}
\hline $\begin{array}{l}\text { Экзогенные } \\
\text { (макро- и мезо-) } \\
\text { факторы }\end{array}$ & $\begin{array}{l}\text { - степень развития финансовых институтов и рынков; } \\
\text { - стадия экономического цикла; } \\
\text { - специфика и стадия жизненного цикла отрасли, в которой } \\
\text { действует компания; } \\
\text { - эколого-экономическое состояние региона. }\end{array}$ \\
\hline $\begin{array}{l}\text { Iе } \\
\text { зные }\end{array}$ & $\begin{array}{l}\text { - специфика и стадия жизненного цикла компании; } \\
\text { - размер компании и ее активы (стоимость активов, их лик- } \\
\text { видность, структура активов, специфичность, наличие и вели- } \\
\text { чина гудвилла компании); } \\
\text { - размер собственного капитала; } \\
\text { - структура капитала (соотношение собственных и заемных } \\
\text { средств); } \\
\text { - структура акционерного капитала; } \\
\text { - текущая и прогнозируемая финансовая устойчивость и фи- } \\
\text { нансовая гибкость компании; } \\
\text { - доступность для компании источников финансирования; } \\
\text { - ESG -факторы. }\end{array}$ \\
\hline $\begin{array}{l}\text { Эндогенные } \\
\text { факторы } \\
\text { Экологического } \\
\text { проекта }\end{array}$ & $\begin{array}{l}\text { - объем требуемых финансовых ресурсов; } \\
\text { - период, на который привлекаются финансовые ресурсы; } \\
\text { - доходность и риск инвестиционного проекта; } \\
\text { - инновационность проекта; } \\
\text { - экологическая, социальная, политическая значимость проекта. }\end{array}$ \\
\hline
\end{tabular}

Источник: составлено автором.

Для того, чтобы подчеркнуть целевую направленность средств в экологические проекты и их особенности, финансирование экологических проектов называют «зеленым финансированием», под которым понимают привлечение финансовых ресурсов из частных и государственных источников, предназначенные для развития экологической инфраструктуры, производства продукции и реализации проектов, что приводит снижению экологических рисков и переходу к зеленой экономике. Также используется понятие «климатического финансирования», которое является разновидностью зеленого финансирования и пред- 
назначено для финансирования мероприятия и проектов, направленных на снижение выбросов парниковых газов, парниковых газов или рост их поглощения, на адаптацию к последствиям изменения климата. В данном исследовании используется более широкое понятие «зеленое финансирование».

В настоящее время, по оценкам экспертов, существуют проблемы финансирования экологических проектов, в частности недофинансирование проектов: по Отчета ЮНЕП «Развитие финансовой системы с учетом устойчивого развития» «для реализации Целей устойчивого развития, включая инфраструктуру, чистую энергию, водные ресурсы и улучшение санитарных условий, по оценкам, требуется 5-7 трлн долларов США инвестиций в год. Развивающимся странам ежегодно не хватает инвестиций на общую сумму 2,5 трлн долларов США, в то время как, если учитывать текущие тенденции, к 2020 году в ведущих экономиках будет наблюдаться дефицит долгосрочных инвестиций в размере 10 трлн долларов США в год» [56]. Только на климатическое финансирование планируется к 2020 году привлечь для развивающихся стран 100 млрд. долл., 383 млрд. долл. было выделено в 2016 году во всем мире, 600 млрд. долл. требуется к 2030 году во всем мире [57].

Поэтому требуется анализ существующих механизмов и инструментов финансирования экологических проектов, рассмотрение перспективных инструментов, использующихся в мировой практике применительно к российскому рынку «зеленых инвестиций». К важнейшим международным институтам, действующие в сфере зеленого финансирования/инвестирования относятся следующие: зеленый климатический фонд, глобальный экологический фонд, группа Всемирного банка, Европейский банк Реконструкции и развития, Европейский инвестиционный банк, Климатические инвестиционные фонды, Инвестиционное учреждение ЕС для Центральной Азии (см. таблицу 11).

Анализ показывает интерес финансовых институтов к финансированию «зелёной» экономики, рост объемов финансирования, расширение инструментов и круга инвесторов.

Для финансирования проектов зеленой экономики используются средства различных фондов (см. таблицу 11). В российской экономике возможно использование средства Фонда национального благосостояния для финансирования инфраструктурных проектов. Так, согласно 
ст. 96.11, п. 4 БК РФ средства фонда могут быть размещены в «долговые обязательства и акции юридических лиц, в том числе российские ценные бумаги, связанные с реализацией самоокупаемых инфраструктурных проектов, перечень которых утверждается Правительством Российской Федерации» [64, ст. 96.11.].

Таблица 11

Международные финансовые институты зеленого финансирования

\begin{tabular}{|c|c|}
\hline Характеристика & Особенности инвестирования \\
\hline \multicolumn{2}{|c|}{ Зеленый климатический фонд } \\
\hline $\begin{array}{l}\text { Фонд был создан в } 2010 \text { году усилиями } \\
194 \text { стран-членов Рамочной конвенции } \\
\text { ООН об изменении климата с целью } \\
\text { инвестирования в проекты климати- } \\
\text { чески устойчивого развития. Фонд по- } \\
\text { могает развивающимся странам, его } \\
\text { цель - содействие перехода к низкоу- } \\
\text { глеродному развитию и климатической } \\
\text { адаптации. }\end{array}$ & $\begin{array}{l}\text { Средства предоставляются аккреди- } \\
\text { тованным при Фонде организациям } \\
\text { в форме инструментов: льготные займы, } \\
\text { субординированные долговые обязатель- } \\
\text { ства, участие в акционерном капитале, } \\
\text { гарантии, гранты. В } 2017 \text { году ресурсы } \\
\text { Фонда составили более } 10,3 \text { млрд. долл. } \\
\text { США. На конец } 2017 \text { г. фондом одобре- } \\
\text { но } 54 \text { проекта на сумму } 2,65 \text { млрд. долл. }\end{array}$ \\
\hline \multicolumn{2}{|c|}{ Глобальный экологический фонд } \\
\hline $\begin{array}{l}\text { Создан в } 1994 \text { г. Инвестирует в проекты } \\
\text { по биоразнообразию, международным } \\
\text { водам, деградации земель, химических } \\
\text { веществ и отходов, смягчению воздей-- } \\
\text { ствия на климат, устойчивое управле- } \\
\text { ние лесами. }\end{array}$ & $\begin{array}{l}\text { Основной финансовый инструмент - } \\
\text { гранты. Планируемый объем средств } \\
\text { на 2014-18 гг. }-4,43 \text { млрд. долл. }\end{array}$ \\
\hline \multicolumn{2}{|c|}{ Группа Всемирного банка } \\
\hline $\begin{array}{l}\text { Планируется выделить до } 2020 \text { года } \\
\text { до } 28 \% \text { средств, необходимых на кли- } \\
\text { матическое финансирование. } \\
\text { Средства предоставляются странам- } \\
\text { партнерам и частным компаниям }\end{array}$ & $\begin{array}{l}\text { Зарезервированный объем средств } \\
\text { на } 2017 \text { год - 61,8 млрд. долл. } \\
\text { В } 2015 \text { г. было предоставлено более } \\
49 \text { млрд. долл. средств. } \\
\text { Инструменты: займы, гранты, вложе- } \\
\text { ния в акционерный капитал, гарантии. }\end{array}$ \\
\hline \multicolumn{2}{|c|}{ Европейский банк Реконструкции и развития } \\
\hline $\begin{array}{l}\text { Планируется предоставить до } 2020 \text { года } \\
\text { не менее } 40 \% \text { средств на зеленое фи- } \\
\text { нансирование }\end{array}$ & $\begin{array}{l}\text { Объемы зеленого финансирования } \\
\text { за 2006-2016 годы - } 24 \text { млрд. евро. }\end{array}$ \\
\hline
\end{tabular}


Окончание табл. 11

\section{Характеристика}

\section{Особенности инвестирования}

\section{Европейский инвестиционный банк}

Планируется выделить не менее 100 млрд. США на климатическое финансирование до 2020 года. Это составит от $25 \%$ и более от всех инвестиций банка и от $35 \%$ и более от общей суммы инвестиций в развивающихся странах.

\section{Климатические инвестиционные фонды}

Созданы в 2008 году группой Всемирного банка для финансирования инвестиций по сокращению выбросов парниковых газов и адаптации.

Климатическое финансирование из данного источника осуществляется через: 1) Фонд чистых технологий (5.5 млрд. долларов США), 2) Фонд стимулирования развития возобновляемой энергии в развивающихся странах (839 млн. долларов США), 3) Пилотный проект по климатической устойчивости (1.2 млрд. долларов США), 4) Программа лесных инвестиций (775 млн. долларов США).

\section{Инвестиционное учреждение ЕС для Центральной Азии}

Инвестиционный фонд IFCA для Центральной Азии, Азиатский инвестиционный фонд AIF, Инвестиционный фонд IFP для Тихоокеанского региона. В 2015 году объем средств на зеленые проекты составил 830 млн. евро
Средства выделяются в виде грантов и «мягких» кредитов (concessional or soft loans) с процентами ниже рыночных и с продолжительным периодом выплаты.

2016 году было выделено на клима. вания.
Предоставляет 5 видов безвозмездной поддержки:

- прямой инвестиционный грант: сокращает расходы для конечных пользователей и бенефициариев путем частичного финансирования инвестиционных расходов;

- грант на техническую поддержку; - субсидия с процентной ставкой: сокращает расходы для конечных пользователей и бенефициариев путем сокращения расходов по процентной ставке; - рисковый капитал: инвестиции в сокращение потенциальных рисков; - залог: поручительство за те или иные виды инвестиции с целью снижения рисков.

Источники: составлено автором по: [57, 58, 59, 60, 61, 62, 63]. 
Одним из инновационных и наиболее перспективных, по нашему мнению, источников финансирования экологических проектов являются «зеленые облигации». Рассмотрим особенности их применения и тенденции развития в мировой экономике, а также возможность применения в российской практике. В научной литературе и практике используются различные названия финансовых инструментов, применяемых для обеспечения реализации проектов в сфере экологии: экологические облигации (pollution control revenue bonds), климатические облигации (climate awareness bonds), инфраструктурные облигации, «зеленые» облигации (green bonds). В данном исследовании мы будем пользоваться термином «зеленые» облигации как получившим наибольшее распространение.

Особенность «зеленых» облигаций по сравнению с классическими - целевое назначение, они предназначены для финансирования проектов в области предотвращения изменения климата, охраны окружающей среды, энергоэффективности, энергосбережения. Эмитентами облигаций выступают: государство, муниципальные органы, корпорации, финансовые институты. В мировой практике «зеленые» облигации получают в настоящее время все большее распространение как инструмент целевого финансирования экологических проектов. Впервые «зеленые» облигации были выпущены в 2007 г. как climate awareness bonds для финансирования проектов в области альтернативных источников энергии и повышения энергоэффективности, а финансовые инструменты под названием «зеленые» облигации (green bonds) выпустил Международный банк реконструкции и развития в 2008 г. [65, с.70].

История «зеленых облигаций» началась в 2007 г., когда группа пенсионных фондов Швеции приняла решение об инвестировании в экологические проекты и искала финансовые инструменты, соответствующие этим целям. Группа обратилась к специалистам Всемирного банка для консультации и через год Всемирным банком была выпущена первая «зеленая облигация» [66]. Финансовые инструменты в рамках проектов развития выпускались Всемирным банком и ранее, с 1947 г., но облигации под проекты конкретной направленности были эмитированы в 2008 г. впервые.

Интерес шведских фондов не был случайным - в 2007 г. ООН опубликовала Обобщающий доклад по изменению климата [67], в котором ученые доказывали с высокой долей вероятности глобальное по- 
тепление вследствие деятельности человека. Этот доклад послужил стимулом для шведских пенсионных фондов к поиску проектов экологической направленности.

«Зеленая» облигация, выпущенная в 2008 г. Всемирным банком, стала основной современного рынка «зеленых» финансовых инструментов. Для ее выпуска была проделана большая работа по согласованию интересов и мнений различных сторон (пенсионных фондов, банков, ЦМКЭИ, Казначейским управлением Всемирного банка) и определены процедуры выпуска таких финансовых инструментов: критерии отбора экологических проектов, получение мнения ЦМКЭИ в качестве «второго» мнения, формирование отчетности о воздействии на окружающую среду. С этого времени и включая 2018 г. Всемирный банк выпустил почти 150 «зеленых» облигаций в 20 валютах, привлек более 13 млрд. долл. США [66], а принципы «зеленых» облигаций используются при разработке других финансовых активов, таких как «голубые» облигации, социальные облигации.

Развитие рынков зеленых облигаций идет активными темпами и поддерживается международными финансовыми организациями. Так в 2017 г. вышла обновленная версия Принципов зеленых облигаций (Green Bond Principles) [68], которая направлена на обеспечение прозрачности рынка инвестиций в экологические проекты и способствует росту информационной эффективности рынка и установлению справедливого ценообразования. В 2016 г. дискуссия о «зеленых» финансах по инициативе Китая впервые была включена в повестку саммита G20 [69]. Инициатива Китая не случайна: в первом полугодии 2018 г. доля китайских зеленых облигаций на рынке составляет 9,3 млрд. долл. США, и они занимают 12\% рынка. А весь рынок (общий объем выпуска зеленых облигаций), по данным Climate Bonds Initiative in partnership with China Central Depositing and Clearing Co, в первом полугодии 2018 года составил 76,9 млрд долл. США [70]. Ма Цзюнь - главный экономист Народного банка Китая отметил, что «сейчас в мире довольно хороший спрос на так называемые «зеленые облигации» [69] и одним из предложений китайских банкиров стало упрощение механизма трансграничных инвестиций для финансирования экологических инициатив и проектов. При этом у рынка огромный потенциал роста: Ма Цзюнь привел такие цифры, характеризующие рынок: «Глобальный спрос на «зеленые» инвестиции огромный. Согласно ряду исследований, объем вложений в эту сферу мог бы 
составить от 3 до 7 триллионов долларов в год. Но существующий рынок «зеленых финансов» все еще очень мал. К примеру, выпуск «зеленых облигаций» составляет меньше 1\% от общей эмиссии ценных бумаг. На рынке кредитования только несколько процентов от общего числа выданных кредитов идет под проекты, которые можно классифицировать как «зеленые»» [69]. Таким образом исследование рынка «зеленых финансов» и его инструментов является актуальным и своевременным. Анализ мирового опыта и тенденций развития данного рынка поможет формулированию предложений о совершенствовании инструментария финансирования экологических проектов в российской экономике.

Рынок «зеленого финансирования» существует уже 13 лет, в 2017 году объем рынка составил 161 млрд. долл. [71 ], 2018 171,2 млрд. долл. [72], 2019 г. - 257, 5 млрд. долл., оценка на 2020 г. 350 млрд. долл. [73]. Рынок развивался скачкообразно: в июле 2007 года - первый в истории выпуск на сумму 600 млн. евро. И только к 2013 году размер эмиссии зеленых облигаций преодолел годовую отметку в 10 млрд. долл. [71], продемонстрировав за четыре года рост в четыре раза. На европейском рынке облигаций зеленые, социальные и устойчивые облигации, за исключением государственных выпусков, уже составляли в среднем 4-5\% с 2017 г. и выросли примерно до 10\% от общего объема облигаций, выпущенных европейскими эмитентами в последнем квартале 2018 г. [74, с.28]. На мировых фондовых биржах существуют сегменты «зеленых» облигаций, что повышает ликвидность и объемы сделок с данными финансовыми инструментами (табл. 12).

Приведем примеры выпуска «зеленых» облигаций различными эмитентами:

- HSBC (банковский холдинг) в 2015 году выпустил зеленые облигации на сумму $€ 500$ млн. Привлеченные средства пошли на финансирование 20 проектов в 10 странах, включая строительство ветряных электростанций в Ирландии, Германии, Турции и других странах, солнечных электростанций в Чехии, Южной Африке и Испании, а также создание предприятий по переработке отходов во Франции и Великобритании [75].

- «Зеленые» ценные бумаги на рынок выпустили французская энергетическая группа EDF, шведская компания Group Vasakronan, занимающаяся недвижимостью, и Bank of America Merill Lynch. У по- 
следнего ставка дохода по облигациям на 500 миллионов долларов составила 1,359 процента, отмечает The Wall Street Journal» [76].

- в августе 2017 г. шотландская компания SSE привлекла 600 млн евро в результате крупнейшего выпуска зелёных облигаций в истории Великобритании. Спрос на данные бумаги компании существенно превысил предложение: подписка на восьмилетние зеленые облигации SSE превысила объём выпуска в 3 раза, ставка купона составила 0,875\% годовых [77].

- в 2019 г. крупнейшей эмиссией сертифицированных зеленых облигаций июня стал выпуск зеленых суверенных зеленых облигаций Правительства Чили в объеме 1,5 млрд. долл. Чили стала первой страной в Латинской Америке, выпустившей суверенные сертифицированные зеленые облигации [78].

Т а блиц а 12

Фондовые биржи, имеющие секции «зеленых» облигаций

\begin{tabular}{|c|c|c|c|}
\hline Name of Stock Exchange & 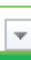 & Type of Dedicated Section & Launch Date \\
\hline Name of Stock Exchange & & Type of Dedicated Section & Launch Date \\
\hline Oslo Stock Exchange & & Green bonds & January 2015 \\
\hline Stockholm Stock Exchange & & Sustainable Bonds & June 2015 \\
\hline London Stock Exchange & & Green bonds & July 2015 \\
\hline Shanghai Stock Exchange & & Green bonds & March 2016 \\
\hline Mexico Stock Exchange & & Green bonds & August 2016 \\
\hline Luxembourg Stock Exchange & & Luxembourg Green Exchange & September 2016 \\
\hline Borsa Italiana & & Green and Social bonds & March 2017 \\
\hline Taipei Exchange & & Green bonds & May 2017 \\
\hline Johannesburg Stock Exchange & & Green bonds & October 2017 \\
\hline Japan Exchange Group & & Green and Social bonds & January 2018 \\
\hline Vienna Exchange & & Green and Social bonds & March 2018 \\
\hline Nasdaq Helsinki & & Sustainable bonds & May 2018 \\
\hline Nasdaq Copenhagen & & Sustainable bonds & May 2018 \\
\hline Nasdaq Baltic & & Sustainable bonds & May 2018 \\
\hline Swiss Stock Exchange & & Green and Sustainability bonds & July 2018 \\
\hline The International Stock Exchange & & Green bonds & November 2018 \\
\hline Frankfurt Stock Exchange & & Green bonds & November 2018 \\
\hline Santiago Stock Exchange & & Green and social bonds & July 2019 \\
\hline Moscow Exchange & & Sustainable bonds & August 2019 \\
\hline Euronext & & Green bonds & November 2019 \\
\hline Hong Kong Exchange & & STAGE, Sustainable and Green Exchange & June 2020 \\
\hline Singapore Stock Exchange & & Green, Social and Sustainability bonds & n. \\
\hline
\end{tabular}

Источник: [75]. 
Многие страны мира используют зеленые облигации в практике финансирования (табл.13). За анализируемый период в один год объемы и темпы роста выпуска зелёных облигаций значительно увеличились. Выделим страны с наибольшими объемами и/ или темпами роста: эта такие развитые страны как Канада (11,6 млрд. долл., 118,87\%), Франция (50,5 млрд. долл., 45,11\%), Германия (28,9 млрд. долл., 44,5\%), Италия (7,3 млрд. долл., 143,35\%), Великобритания, начавшая выпуск в 2018 г. - 5,8 млрд. долл., лидером являются США (107,8 млрд. долл., 138,40\%). Среди стран БРИК только Российская Федерация не выпускала зеленые облигации на момент получения данных, лидером в этой группе стран является Китай (63 млрд. долл., 75,98\%).

Т а блица 13

Выпуск зеленых облигаций в различных странах мира, млрд. долл. США

\begin{tabular}{|l|c|c|c|}
\hline \multicolumn{1}{|c|}{ Страна } & $\begin{array}{c}\text { Выпуск } \\
\text { зеленых } \\
\text { облигаций, } \\
\text { на 09.2017 }\end{array}$ & $\begin{array}{c}\text { Выпуск } \\
\text { зеленых } \\
\text { облигаций } \\
\text { на 09.2018 }\end{array}$ & Темп роста,\% \\
\hline Аргентина & 0.4 & 0,5 & 25,00 \\
\hline Австралия & 4,1 & 7,3 & 78,05 \\
\hline Бангладеш & 0,0 & 0,0 & 0,00 \\
\hline Барбадос & 0,0 & 0,0 & 0,00 \\
\hline Бразилия & 3,9 & 4,4 & 12,82 \\
\hline Камбоджи & 0,0 & 0,0 & 0,00 \\
\hline Канада & 5,3 & 11,6 & 118,87 \\
\hline Китай & 35,8 & 63,0 & 75,98 \\
\hline Колумбия & 0,3 & 0,5 & 66,67 \\
\hline Коста Рика & 0,5 & 0,5 & 0,00 \\
\hline Эквадор & 0,0 & 0,0 & 0,00 \\
\hline Египет & 0,0 & 0,0 & 0,00 \\
\hline Эфиопия & 0,0 & 0,0 & 0,00 \\
\hline Франция & 34,8 & 50,5 & 45,11 \\
\hline Германия & 20,0 & 28,9 & 44,5 \\
\hline Гондурас & 0,0 & 0,0 & 0,00 \\
\hline Индия & 5,5 & 7,2 & 40,00 \\
\hline
\end{tabular}


$\Gamma$ Гаßа 2

Окончание табл. 13

\begin{tabular}{|l|c|c|c|}
\hline \multicolumn{1}{|c|}{ Страна } & $\begin{array}{c}\text { Выпуск } \\
\text { зеленых } \\
\text { облигаций, } \\
\text { на 09.2017 }\end{array}$ & $\begin{array}{c}\text { Выпуск } \\
\text { зеленых } \\
\text { облигаций } \\
\text { на 09.2018 }\end{array}$ & Темп роста,\% \\
\hline Индонезия & 0,0 & 2,0 & - \\
\hline Италия & 3,0 & 7,3 & 143,33 \\
\hline Япония & 2,3 & 7,8 & 239,13 \\
\hline Казахстан & 0,0 & 0,0 & 0,00 \\
\hline Кения & 0,0 & 0,0 & 0,00 \\
\hline Республика Корея & 1,7 & 3,8 & 123,53 \\
\hline Российская Федерация & 0,0 & 0,0 & 0,00 \\
\hline Саудовская Аравия & 0,0 & 0,0 & 0,00 \\
\hline Сингапур & 0,6 & 1,8 & 200 \\
\hline Южная Африка & 1,3 & 1,4 & 7,69 \\
\hline Шри Ланка & 0,0 & 0,0 & 0,00 \\
\hline Швейцария & 0,1 & 1,1 & 1000 \\
\hline Таиланд & 0,0 & 0,1 & - \\
\hline Турция & 0,0 & 0,0 & 0,00 \\
\hline Великобритания & 0,0 & 5,8 & - \\
\hline США & 45,6 & 107,8 & 136,40 \\
\hline Вьетнам & 0,0 & 0,03 & - \\
\hline
\end{tabular}

Источник: [79].

Отметим юридические особенности выпуска «зеленых» облигаций. При эмиссии «зеленых» облигаций эмитенты ориентируются на «Принципы зеленых облигаций» [80], которые представляют собой добровольные стандарты эмиссии данных ценных бумаг. Цель данных Принципов - обеспечить участникам рынка достоверную информацию для лучшего понимания ожидаемых результатов от инвестирования в экологические проекты посредством «установления стандартов прозрачности, раскрытия информации и отчетности» [80]. Следует отметить, что Принципы носят рекомендательный характер. Они основываются на четырех элементах: 1) использование средств, 2) процесс оценки и отбора проектов, 3) управление средствами, 4) отчетность. 
1. Использование средств. Поступления от эмиссии «зеленых» облигаций должны направляться на реализацию зеленых проектов, в т.ч. на НИОКР. Проекты должны приносить экологическую пользу, которую необходимо оценить с помощью количественных и качественных показателей. При рефинансировании средств необходимо разъяснение того, в какие проекты средства будут рефинансироваться. Принципы включают примерный список категорий экологических проектов:

«- возобновляемые источники энергии (включая производство, передачу, оборудование и изделия);

- эффективность использования электроэнергии (энергоэффективность в новых и отремонтированных зданиях, хранение электроэнергии, центральное теплоснабжение, интеллектуальные сети, оборудование и изделия);

- предотвращение загрязнения и контроль (включая проекты в сфере очистки сточных вод, сокращения выбросов в атмосферу, контроля за парниковыми газами, восстановления почв, предотвращения загрязнений, сокращения загрязнений, переработки отходов, эффективной переработки отходов в электроэнергию, производства товаров с добавленной стоимостью из отходов и в результате переработки и связанного с указанными сферами деятельности контроля состояния окружающей среды);

- экологически устойчивое управление живыми природными ресурсами и землепользованием (в том числе экологически устойчивое сельское хозяйство, экологически устойчивое животноводство, не причиняющие ущерба климату сельскохозяйственные технологии, например, защита биологических культур или капельное орошение, экологически устойчивое рыболовство и аквакультура, экологически устойчивое лесное хозяйство, включая лесонасаждение или лесовосстановление, сохранение или восстановление природных ландшафтов);

- сохранение земного и водного биоразнообразия (включая охрану прибрежных, морских и водораздельных сред);

- экологически чистый транспорт (например, электрический, гибридный, общественный, железнодорожный, немоторизованный, мультимодальный транспорт, инфраструктура для экологически чистых транспортных средств и сокращение вредных выбросов);

- устойчивое управление водными ресурсами и сточными водами (включая устойчивую инфраструктуру для чистой и/или питьевой 
воды, очистку сточных вод, устойчивые городские системы дренажа и регулирование речного русла, и другие методы противопаводковой защиты);

- адаптация к изменению климата (включая системы информационной поддержки, такие как системы наблюдения за климатом и системы раннего предупреждения);

- экологически эффективные и/или адаптированные продукты безотходной экономики, производственные технологии и процессы (такие как разработка и внедрение экологически чистых продуктов, экомаркировка или экологическая сертификация, экономная упаковка и распределение);

- зеленые здания, отвечающие региональным, национальным или международно-признанным стандартам или сертификациям».

2. Процесс оценки и отбора проектов. Делается акцент на необходимости донесения целей проекта до инвесторов; раскрытие процедуры соответствия проектов категории экологических; соответствующие квалификационные критерии и процедуры, позволяющие оценить и управлять экологическими и социальными рисками.

3. Управление средствами. Выпуск зеленых облигаций должен предусматривать, что средства, полученные в ходе размещения ценных бумаг, будут аккумулированы на отдельном счете (портфеле), предназначенном для финансирования заявленных целей и проектов. Способ учета средств должен быть закреплен во внутренней политике и процедурах эмитента. Рекомендовано привлечение независимого аудитора для проверки адекватности применяемых процедур и методов учета и контроля использования средств.

4. Отчетность. Эмитентам необходимо предоставлять отчет по проектам, который должен содержать такую информацию как: список экологических проектов, описание проектов, суммы направленных средств, ожидаемые результаты и эффекты.

Кроме того, Принципы рекомендуют эмитентам использовать независимую оценку для подтверждения соответствия зеленых облигаций четырём представленным выше Принципам.

Принципы носят добровольный характер, получение соответствия облигаций статуту «зеленый» формально не влияет на рейтинг. Но отметим, что рейтинг таких облигаций высок, в том числе и потому, что эмитентами в большинстве являются крупнейшие банки, компании, государственные и муниципальные органы, такие как Всемирный 
банк (МБРР), Европейский инвестиционный банк, Международная финансовая корпорация, Toyota, Ile de France, Electricite de France, Apple Ink. И другие. В тоже время специалисты отмечают, что при условии добровольности Принципов инвесторы не застрахованы от риска не следования эмитентами принимаемым обязательствам. Так исследователи Гутборг М., Храплива Ю, Володин С. цитируют проспекты эмиссии зеленых облигаций и подчеркивают, что в них «допускается возможность невыполнения таких обещаний» [81], что увеличивает моральный риск инвесторов таких ценных бумаг.

В 2019 г. в рамках Плана действий по финансированию устойчивого развития Европейская комиссия поручила TEG подготовить доклад о стандарте зеленых облигаций EC (EU green bond standard, EU GBS). Промежуточный доклад о стандарте зеленых облигаций ЕС был подготовлен в марте 2019 года (TEG interim report on EU green bond standard).

Каковы интересы участников рынка «зеленого финансирования»? Ключевыми инвесторами зеленых облигаций являются пенсионные фонды и страховые компании, инвестиционные фонды, которые используют в своей деятельности «длинные» деньги и ориентированы на консервативные инвестиционные стратегии. Их интерес к зеленому финансированию высок и определяется такими факторами как $[65$, с.73-74]: быстрое размещение облигаций на рынках с момента официального начала продаж; спрос (сумма подписки) на такие облигации часто выше размера эмиссии; опросы инвесторов свидетельствуют о повышенном интересе к зеленым финансовым инструментам; развитием фондов зеленых инвестиций. Инвесторов привлекает высокий рейтинг зеленых финансовых инструментов (45\% зеленых облигаций, выпущенных в 2014 г. имели рейтинг А3, 16\% - A2) а эмитентов - низкие купонные выплаты (доходность) и длительный срок погашения (более 60\% бумаг - более 10 лет, около 30\% - 5-10 лет, около 6\% - 3-5 лет) (согласно данным [65, с.75]). Эксперты отмечают, что спрос на зеленые облигации превышает предложение, а управляющие фондов «диверсифицируют свои инвестиционные критерии, включая зелёный фактор», отмечает Financial Times [17]. Многие крупные институциональные инвесторы отказываются от инвестирования с проекты, не соответствующие принципам «зеленой экономики». Так «японский государственный пенсионный инвестиционный фонд, под управлением которого находится $\$ 1,3$ трлн, поставил перед 
собой цель размещать 10\% своих активов в компании, соответствующие определённым экологическим, социальным и управленческим (governance) критериям» [17]. «Пенсионный фонд Дании PenSam принял решение отказаться от инвестиций в 26 акций нефтяных компаний совокупной стоимостью $€ 17,4$ млн. Решение о пересмотре структуры инвестиционного портфеля фонда принято в целях поддержки Парижского соглашения ООН об изменении климата, регулирующее меры по снижению углекислого газа в атмосфере с 2020 года. Начиная с 2016 года пенсионный фонд уже не инвестирует в более чем 100 акций компаний, занятых в сфере производства нефти, угля и битуминозных песков» [82]. «4 июня 2019 года опубликована информация о том, что шведский пенсионный фонд АР2 принял решение отказаться от инвестиций в 60 табачных компаний, а также в акции компаний, связанных с проведением модернизации и технического обслуживания систем ядерного оружия. Решение о пересмотре структуры инвестиционного портфеля фонда принято в целях поддержки конвенции $\mathrm{OOH}$ в области борьбы против табака и табачной продукции, а также международного договора о нераспространении ядерного оружия» [83].

В распоряжении церкви Швеции (Church Of Sweden) находятся активы стоимостью 36 млрд. шведских крон. Главной управляющей компанией церкви является американская компания «Generation Investment Management» с инвестиционным фондом «Generation». Инвестиции в рамках фонда направляются только в компании, разделяющие принципы устойчивого развития; среди ценных бумаг с фиксированной доходностью преобладают «зеленые» облигации, имеющие строгую целевую направленность, выпуски этих облигаций проходят процедуры верификации и получения рейтингов. Наиболее значимые инвестиции церкви - это инвестиционные проекты, имеющие социальную и экологическую значимость, такие как: SPP Green Bond Fund (проекты возобновляемых источников энергии, очистки воды и т.п.), фонд микрофинансирования SEB, Green for Growth Fund (выдача займов на проекты энергоэффективности и возобновляемые источники энергии в Юго-Восточной Европе, основные получатели займов - муниципалитеты и небольшие компании). Средняя доходность инвестиций за десятилетний период - 6,2\% годовых) [84].

Инвесторы Германии активно инвестируют в зеленую экономику страны. Берлинская газета Tagesspiegel летом 2019 г. опубликовала исследование об инвестициях в зеленую экономику Германии, 
в котором отмечает, что за последние три года «в экологические акции, фонды и сертификаты было инвестировано порядка 3 млрд евро. Только за первые три квартала текущего года в котирующиеся на бирже экологические акции было вложено 552 млн евро. За последние же два года капиталовложения в охрану окружающей среды увеличились в 36 раз. Только в 18 допущенных в Германии экологических фондов было вложено 3 млрд евро. Среднее увеличение стоимости экологических ценных бумаг за девять месяцев прошлого года составило 24\%» [85].

Согласно опросу, проведенному немецкой управляющей компанией Union Investment Institutional « $92 \%$ инвестиционных компаний учитывают ESG факторы при вложении средств, затем следуют благотворительные организации и религиозные организации $-86 \%$, пенсионные фонды - 56\%, страховые компании $-49 \%$, банки $-41 \%$, крупные финансовые компании - 40\%. По мнению опрошенных компаний, стоимость активов, которые находятся в инвестиционном портфеле, является очень важным мотивационным фактором для интеграции ESG-факторов в инвестиционную стратегию» [82]. При этом Tagesspiegel отмечает, что «доля экологических капиталовложений в целом составляет пока лишь 0,4\% всех капиталовложений» [85].

Подход к инвестированию, применяемый в данных примерах, является «ответственным инвестированием» и получает все большее распространение среди инвесторов, влияющее на мировоззрение инвесторов и оказывающее влияние на финансовые рынки. Этот феномен лег в основу исследования французской управляющей компании Natixis Investment Managers, результаты которого она опубликовала в мае 2019 г. [86]. «Согласно выводам управляющей компании, профессиональные инвесторы по всему миру все больше начинают осознавать риски и возможности, которые связаны с экологическими, социальными и факторами корпоративного управления (ESG). Так, согласно проведенному опросу, шесть из десяти институциональных инвесторов полагают, что вложение средств с учетом ESG-факторов может принести значительный доход» [86, с.4].

На мировых рынках «зеленые» облигации обращаются не только как классические облигации, развиваются и другие виды: проектные облигации; облигации, обеспеченные потоком платежей (доходные); облигации, обеспеченные имуществом (подробнее - табл.14, приложение В). 
Появляются новые виды экологических финансовых инструментов: так, наряду с «зелеными» облигациями выпускаются «голубые» облигации, предназначенные для финансирования проектов в области развития рыбного хозяйства, планируется разработка критериев финансовых инструментов для проектов и программ в сфере обращения с отходами The Waste Management Criteria, на основе которых будет проводиться отбор проектов, которые соответствуют концепции низкоуглеродной экономики и целям, зафиксированным в Парижском соглашении по ограничению глобального повышения температуры выше $2^{\circ} \mathrm{C}$ [73].

Таблица 14

Виды «зеленых» облигаций и их особенности

\begin{tabular}{|l|l|}
\hline \multicolumn{1}{|c|}{$\begin{array}{c}\text { Виды «зеленых» } \\
\text { облигаций }\end{array}$} & \multicolumn{1}{c|}{ Особенности } \\
\hline $\begin{array}{l}\text { Облигации с общим } \\
\text { обязательством }\end{array}$ & $\begin{array}{l}\text { Выплаты по облигациям не связаны с результатами ре- } \\
\text { ализации зеленых проектов, инвесторы не несут про- } \\
\text { ектных рисков }\end{array}$ \\
\hline Проектные облигации & $\begin{array}{l}\text { Доходы обеспечены реализацией зеленого проекта. Ин- } \\
\text { весторы имеют право прямого воздействия на риск } \\
\text { проекта без обращения к эмитенту. Облигации обеспе- } \\
\text { чены активами эмитента (не только зелеными). }\end{array}$ \\
\hline Доходные облигации & $\begin{array}{l}\text { Доходы - от реализации товаров и услуг зеленого проек- } \\
\text { та, облигации обеспечены только «зелеными»активами. }\end{array}$ \\
\hline $\begin{array}{l}\text { Секъюритизированные } \\
\text { облигации }\end{array}$ & $\begin{array}{l}\text { Облигации, обеспеченные пулом активов, м.б. как } \\
\text { 1) изъяты из баланса эмитента, 2) так и оставаться } \\
\text { на балансе эмитента. Риск неисполнения обязательств } \\
\text { ложится на инвестора. Право регресса обращается } \\
\text { к пулу зеленых (или обеспечивающих) активов, являю- } \\
\text { щихся залогом. Инвесторы диверсифицируют риски, } \\
\text { инвестируя в небольшие неликвидные активы. Эмитен- } \\
\text { ты получают доступ к дешевому финансированию. }\end{array}$ \\
\hline
\end{tabular}

Источник: составлено автором по [65, 87].

Планируется выпуск «переходных» облигаций (transition bonds). С инициативой их выпуска в июне 2019 г. выступила французская управляющая компания AXA Investment Managers. Средства, привлеченные путем выпуска данных ценных бумаг, помогут компаниям, не имеющим возможности выйти на рынок зеленых облигаций, стать 
более экологичными [83, с.10]. Рост более широкого диапазона социально сознательных долговых обязательств отмечает в своем отчете за 2018 г. компания Climate Bonds Initiative, констатируя отчетливый рост таких финансовых инструментов как облигации ЦУР, социальные облигации, голубые облигации, что расширяет возможности для ответственных инвестиций [88].

Планируется выпуск «переходных» облигаций (transition bonds). С инициативой их выпуска в июне 2019 г. выступила французская управляющая компания AXA Investment Managers. Средства, привлеченные путем выпуска данных ценных бумаг, помогут компаниям, не имеющим возможности выйти на рынок зеленых облигаций, стать более экологичными [83, с.10]. Рост более широкого диапазона социально сознательных долговых обязательств отмечает в своем отчете за 2018 г. компания Climate Bonds Initiative, констатируя отчетливый рост таких финансовых инструментов как облигации ЦУР, социальные облигации, голубые облигации, что расширяет возможности для ответственных инвестиций [88].

Инвестиционные фонды не только увеличивают долю «зеленых» финансовых инструментов в своих портфелях, но и начинают поддерживать не только крупные экологические проекты, но и проекты среднего и малого бизнеса. Так 09 июля 2019 года на Международном финансовом форуме (International Finance Forum ) в Париже французская управляющая компания Amundi совместно с Европейским инвестиционным банком (European Investment Bank, EIB) объявили о совместном партнерстве, направленном на развитие инструментов зеленого финансирования в Европе (Partnership to expand Green Finance in Europe). В рамках партнерства они запускают программу The Green Credit Continuum programme, которая предполагает создание инвестиционного фонда, средства которого будут вложены в высокодоходные корпоративные зеленые облигации (highyield corporate green bonds), частные зеленые долговые финансовые инструменты (green private debt) и зеленые секьюритизированные зеленые кредиты (green securitised credit). Первоначальные инвестиции Европейского инвестиционного банка в формируемый фонд составят около $\$ 60$ млн с возможностью дополнительного увеличения вложений в течение трех лет до $€ 1$ млрд. Средства фонда будут направлены на финансирование небольших зеленых проектов, а также малых и средних компаний, деятельность которых связана с охраной окружающей среды [82]. 


\section{Выводы}

Таким образом «зеленые» облигации характеризуются следующими особенностями:

1) целевой характер инвестиций в экологические проекты;

2) наличие международных и национальных стандартов, носящих добровольный характер, но в отдельных странах (Китай) стандарты обязательны [65, с.79];

3) высокий рейтинг зеленых облигаций, который свидетельствует о более низком риске и повышает привлекательность инвестиций в зеленые финансы;

4) длительные сроки обращения зеленых облигаций, которые репрезентативны срокам реализации и окупаемости экологических проектов, в отличие от других, обычно более коротких способов финансирования;

5) признание данного инструмента со стороны участников рынка, что способствует быстрому развитию зеленых сегментов фондового рынка даже в развивающихся странах.

«Зеленые» облигации способствуют решению экологических проблем:

1) повышают уровень осведомленности инвесторов о проблемах изменения климата и показывают возможные направления решения проблем;

2) позволяют получить доход, не жертвуя прибыльностью и ликвидностью;

3) помогают повысить социальную ответственность инвесторов и эмитентов;

4) повышают открытость и прозрачность компаний и проектов;

5) способствуют развитию рынков, где одновременно учитывается, а не противопоставляется, социальная значимость и стоимостная доходность инвестиций.

\section{2. Анализ механизмов и инструментов финансовой поддержки развития зеленых проектов в российской экономике ${ }^{14}$}

Среди российских ученых, занимающихся исследованием проблем финансирования экологических проектов, в том числе с помощью «зеленых» облигаций, отметим работы О.В. Богачевой и О.В. Смороди-

${ }^{14}[54$, п.3.2, испр. и перераб.]. 
нова (Центр бюджетной политики Научно-исследовательского финансового института) $[65,89]$, Е. Тютюкиной, Т. Седаш, Е Каменевой (Финансовый университет при Правительстве Российской Федерации) [90-96], М. Гутборга, Ю. Храпливой (компания Baker McKenzie), С. Володина (ВШЭ) [97], Яковлев И., Кабир Л., Никулина С. [98], Ларионова И. [99] и др.

В российской экономике «зеленые» облигации, несмотря на положительные мнения специалистов о возможностях использования такого рода финансовых инструментов и необходимость поиска дополнительных источников финансирования экологических проектов, помимо бюджетных средств, только начинают внедряться в практику. В качестве немногочисленных исключений приведем факт из работы Е. Тютюкиной, Т. Седаш «Экологические облигации и депозиты как источник финансирования природоохранных мероприятий», в которой отмечается, что в российской экономике муниципальными и региональными органами власти могут быть эмитированы облигации внутреннего экологического займа (ОВЭЗ) для финансирования региональных проектов по охране окружающей среды и как пример эмиссии экологических облигаций в России приводится эмиссия облигаций областного займа «Ярославский экологический заем 1995-1998 гг.», утвержденная постановлением губернатора Ярославской области в 1995 г. [90, с.59].

Известные российские бизнесмены положительно относятся к возможности инвестирования в зеленые облигации. Так, Павел Теплухин - руководитель компании Matrix Capital, «с воодушевлением говорит о новом классе активов («зеленые» рублевые облигации), который должен позволить партнерам участвовать в создании перспективного рынка на десятки миллиардов долларов. По оценке Минприроды, в 2017 российский бюджет и компании (были - $A$ ) намерены вложить в экологическую модернизацию промышленных объектов около \$3 млрд. О потенциальном интересе к идее экобондов ... заявляли «Сибур» и «Норильский никель» [100].

«Норильский Никель» планировал покрыть затраты на инвестиции в зеленые проекты за счет выпуска зеленых облигаций [101], но выпуск не состоялся. Банк России в лице своего первый зампреда Сергей Швецов в декабре 2017 г. заявил о возможности выпуска зеленых облигаций в российской экономике в 2018г. : «Первые «зеленые» облигации появятся в России в следующем году, они будут выпущены в формате евробондов. Мы посмотрим на динамику и если увидим 
высокий спрос на эти бумаги на внутреннем рынке, то уже рассмотрим возможность законодательно закрепить возможность выпуска этих бумаг», - заявил он» [102].

Эксперты отмечают, что компании фактически выпускают облигации, предназначенные для финансирования экологических проектов (например, в апреле 2017 г. компания ООО «Экология-Новосибирск» анонсировала размещение облигаций на 1 млрд руб. для строительства в регионе двух мусороперерабатывающих комплексов [цитировано по: 97, c.51.]), но данные бумаги не прошли процедуру сертификации на соответствие Принципам зеленых облигаций.

Первый выпуск «зеленых» облигаций в России состоялся 19 декабря 2018 г., их разместила на Московской бирже компания «Ресурсосбережение XМАO», номинальная стоимость облигаций составляет 1,1 млрд руб., доходность размещения составила 9,76\%, купон облигаций привязан к инфляции и ключевой ставке Банка России [103]. Выпущенные облигации, согласно заключению рейтингового агентства Rating-Agentur Expert RA, соответствуют Принципам «зеленых» облигаций (Green Bond Principles 2018), разработанными Международной ассоциацией рынков капитала (ICMA). Средства от размещения облигаций, как отмечает компания БКС, «будут направлены на финансирование концессионного проекта создания комплексного межмуниципального полигона для размещения, обезвреживания и обработки ТКО для городов Нефтеюганска, Пыть-Яха и поселений Нефтеюганского района» [103].

Отметим, что 2019 год стал прорывным годом в области внедрения стандартов «зеленого» инвестирования в практику российской экономики с целью активизации финансовой поддержки экологических проектов. Проблематика борьбы с климатическими изменениями, стимулирования внедрения экологических проектов была в зоне приоритетов федерального правительства, представителей финансовых сфер, инвесторов и корпораций.

Выделим наиболее важные события и документы, способствующие становлению рынка ответственного финансирования в России в 2019 году (обзор подготовлен по результатам анализа материалов НАКДИ [104]):

- опубликован паспорт национального проекта «Экология», утвержденный президиумом Совета при Президенте Российской Федерации по стратегическому развитию и национальным проектам (протокол от 24 декабря 2018 г. № 16) - февраль 2019 г. [105]; 
- первый в России выпуск «зеленых» облигаций компании «Ресурсосбережение XMAО» включен в список международных «зеленых» облигаций Environmental Finance Bond Database, Россия включена в список стран, выпустивших «зеленые» облигации - март;

- рейтинговое агентство «Эксперт РА» утвердило методологию выражения независимого заключения о соответствии облигаций принципам зеленых облигаций (second party opinion) [106] - апрель;

- Правительство России утвердило правила субсидирования затрат на выплату купонов по облигациям в рамках инвестиционных проектов по внедрению НДТ (наилучшие доступные технологии) [107] - май;

- Президент России утвердил доктрину национальной энергетической безопасности [108] - май;

- компания РЖД анонсировала выпуск «зеленые» облигации на сумму 500 млн. евро под 2,2\% годовых [109], все средства направляются на реализацию «зеленых» проектов, в т.ч. связанных с приобретением пассажирских поездов «Ласточка» и электровозов;

- международная компания рынков капитала ICMA включила выпуск «зеленых» облигаций компании «Ресурсосбережение XМАО» в международную базу данных - май;

- Московская биржа при поддержке Минэкономразвития создала сектор устойчивого развития, который будет состоять из трех сегментов: «зеленых» облигаций, «социальных» облигаций и национальных проектов - август;

- завершилась ратификация парижского соглашения Россией 23 сентября 2019 г., в день проведения саммита ООН по борьбе с климатическими изменениями, премьер-министр РФ Д.А. Медведев подписал постановление правительства, связанное с принятием Россией Парижского соглашения по климату [110] - сентябрь;

- Банком России подготовлена Концепция организации в России методологической системы по развитию зеленых финансовых инструментов и проектов ответственного инвестирования [2] - октябрь;

- банк «Центр-Инвест» разместил первые в России биржевые «зеленые» облигации объемом 250 млн. руб. [111] - ноябрь;

- Совкомбанк презентовал выпуск «зеленых» облигаций для широкого круга инвесторов компании ООО «СФО РуСол $1 »$, соответствие ценных бумаг принципам «зеленых» облигаций подтвердило агентство АКРА [112] - декабрь; 
- компания АО «Коммерческая недвижимость ФПК «Гарант-Инвест» разместила выпуск «зеленых» облигаций на сумму 500 млн. руб., агентство Эксперт РА» подтвердило соответствие выпуска принципам «зеленых» облигаций [110] - декабрь;

- рейтинговое агентство «Эксперт РА» утвердило методологию присвоения рейтингов ESG. Данный рейтинг «представляет собой мнение кредитного рейтингового агентства «Эксперт РА» о том, в какой степени процесс принятия ключевых бизнес-решений в компании ориентирован на устойчивое развитие в экологической, социальной и экономической сферах» [114] - декабрь.

Рассмотрим более подробно ключевые, по нашему мнению, события 2019 г. для становления и развития рынка «зеленых» облигаций в России.

В 2019 году стал активно развиваться «зеленый» сектор на фондовых биржах. Были размещены первые выпуски «зеленых» облигаций как компаний реального сектора экономики, так и финансовых институтов. В Секторе устойчивого развития Московской биржи котируются облигации банка «Центр-Инвест» и компании АО «Коммерческая недвижимость ФПК «Гарант-Инвест». Информация о выпусках представлена в таблице 15 .

Таблица 15

«Зеленые» облигации российских компаний

Даты выпуска и характеристики

Компания «Ресурсосбережение ХМАО»

Дата размещения - 19.12.2018,

Общий объем выпуска - 1,1 млрд рублей. Ставка первого купона - 10\%, доходность купонов со второго по двенадцатый определяется как максимальное значение одной из величин: индекса потребительских цен в РФ в годовом выражении $+4,5 \%$, или ключевой ставки Банка России+1,5\%. Облигации включены в раздел «Первый уровень» Списка ценных бумаг, допущенных к торгам ПАО Московская Биржа.
Проект по строительству комплексного межмуниципального полигона для размещения, обезвреживания и обработки твердых коммунальных отходов (КММП) для городов Нефтеюганск и Пыть-Яха, поселений Нефтеюганского района Ханты-Мансийского автономного округа (XМАО)-Югра. 
Окончание табл. 15

\begin{tabular}{|c|c|}
\hline Даты выпуска и характеристики & Направления финансирования \\
\hline \multicolumn{2}{|c|}{ Компания РЖД } \\
\hline $\begin{array}{l}\text { Объем - } 500 \text { млн. евро; } \\
\text { Ориентир по купону - 2,2\%. }\end{array}$ & $\begin{array}{l}\text { Средства направляются на реализацию } \\
\text { «зеленых» проектов, в т.ч. связанных } \\
\text { с приобретением пассажирских поез- } \\
\text { дов «Ласточка» и электровозов. }\end{array}$ \\
\hline \multicolumn{2}{|c|}{ Банк «Центр-Инвест» } \\
\hline $\begin{array}{l}\text { Объем - } 250 \text { тыс. шт., номинал - } \\
1000 \text { руб., дата размещения - } 15.11 .2019 \text {, } \\
\text { дата погашения }-13.11 .2020 \text {, ставка те- } \\
\text { кущего купина }-8 \%, \text { доходность } \\
\text { по цене последней сделки }-7,92 \% .\end{array}$ & $\begin{array}{l}\text { Финансирование и рефинансирование } \\
\text { кредитов для реализации энергоэффек- } \\
\text { тивных проектов, возобновляемых ис- } \\
\text { точников энергии и финансирование } \\
\text { экологически чистого транспорта. }\end{array}$ \\
\hline \multicolumn{2}{|c|}{ Компания ООО «СФО РуСол 1» } \\
\hline $\begin{array}{l}\text { Совкомбанк планирует до конца года } \\
\text { выступить организатором размещения } \\
\text { облигаций ООО «СФО РуСол } 1 » \text { с под- } \\
\text { твержденным рейтингом аналитическо- } \\
\text { го агентства АКРА. Объем выпуска - } \\
5,7 \text { млрд. рублей. Закрытая подписка } \\
\text { среди квалифицированных инвесторов. }\end{array}$ & $\begin{array}{l}\text { Рефинансирование банковских креди- } \\
\text { тов, выданных на цели строительства } \\
\text { двух солнечных электростанций (СЭС) } \\
\text { в Астраханской области. }\end{array}$ \\
\hline \multicolumn{2}{|c|}{ АО «Коммерческая недвижимость ФПК «Гарант-Инвест» } \\
\hline $\begin{array}{l}\text { Объем - } 500 \text { тыс. шт., номинал - } \\
1000 \text { руб., дата размещения - 17.12.2019, } \\
\text { дата погашения }-15.12 .2022 \text {, ставка те- } \\
\text { кущего купина }-11,5 \%,\end{array}$ & $\begin{array}{l}\text { Финансирование модернизации торго- } \\
\text { вых и многофункциональных центров, } \\
\text { внедрение энергосберегающих и «зеле- } \\
\text { ных технологий» в рамках инвестици- } \\
\text { онной «Программы РЕ» - с целью реа- } \\
\text { лизаци и стратегии устойчивого } \\
\text { развития, снижения негативного воздей- } \\
\text { ствия на окружающую среду, повыше- } \\
\text { ния комфорта для жителей и реализации } \\
\text { зеленых технологий в недвижимости. }\end{array}$ \\
\hline
\end{tabular}

Источник: составлено автором на основе: $[111,112,113,115,116,117]$.

Создание сектора устойчивого развития Московской биржеей явилось значимым событием для российского финансового рынка зеленого финансирования. Данный сектор будет состоять из трех сегментов: «зеленых» облигаций, «социальных» облигаций и национальных проектов [118]. С связи с этим с12 августа 2019 г. изменились 
правила листинга биржи. Как отмечает на бирже, «в сегменты «зеленых» и «социальных» облигаций могут включаться ценные бумаги российских и иностранных эмитентов при соответствии выпуска, эмитента или инвестиционного проекта принципам в области «зеленого» / «социального» финансирования Международной ассоциации рынков капитала (International Capital Market Association, ICMA) либо Международной некоммерческой организации «Инициатива климатических облигаций» (Climate Bonds Initiative, CBI), а также при наличии независимой внешней оценки, подтверждающей соблюдение указанных принципов» [118].

Биржа информирует, что «в сегмент национальных проектов могут включаться облигации российских и иностранных эмитентов при соответствии выпуска, эмитента или инвестиционного проекта задачам и результатам национальных проектов «Экология», «Демография», «Здравоохранение», федеральных проектов, в том числе «Внедрение наилучших доступных технологий», а также при наличии решения органов или должностных лиц государственной власти, межведомственных комиссий о соответствии задачам и результатам одного из проектов, указанных в Правилах листинга» [118].

На Московской бирже действуют и другие сегменты, которые, по нашему мнению, интересны для получения финансирования для проектов экологической направленности: это сектор роста и рынок инноваций и инвестиций.

Сектор роста [119] ставит своей задачей содействие привлечению инвестиций компаниями малой и средней капитализации.

Эмитентами могут выступать компании с объемом выручки не менее 120 млн. рублей;

Максимальное значение выручки не более 10 млрд. рублей для эмитентов облигаций и не более 25 млрд. рублей для эмитентов акций;

Для эмитентов облигаций минимальный объем выпуска - 50 млн. рублей, при наличии гарантии/поручительства от одного из институтов развития - 30 млн. рублей;

Срок существования эмитента - не менее 3 лет;

Приоритетным эмитентами являются субъекты МСП; компании, демонстрирующим рост финансовых показателей; промышленные компании; компании с экспортной выручкой; компании, получившим поддержку от Корпорации МСП, МСП Банка, ФРП, РЭЦ, РФПИ; 
Преимущества:

Меры господдержки эмитентов: субсидии и компенсации эмитентам МСП, предусмотрены Постановлением Правительства № 532 от 30 апреля 2019 года

Поддержка со стороны институтов развития: поручительство/ гарантии по облигационным выпускам от Корпорации МСП, участие МСП-Банка в размещении облигаций эмитентов МСП)

Сниженные требования листинга по free-float для акций II-го уровня -500 млн. руб. (вместо 1 млрд. руб.) для обыкновенных акций и 250 млн. руб. (вместо 500 млн. руб.) для привилегированных акций.

Ключевые инструменты: облигации, облигации без проспекта ценных бумаг, биржевые облигации, облигации в рамках секьюритизации кредитов МСП; акции (обыкновенные и привилегированные); паи ЗПИФов, инвестирующих в МСП.

На 02.01.2019 г. эмитентами являлись 30 компаний (список компаний - см. приложение В).

Рынок Инноваций и Инвестиций Московской Биржи (РИИ Московской Биржси) [120] главной задачей которого является содействие привлечению инвестиций в компании инновационного сектора российской экономики.

Цели Рынка Инноваций и Инвестиций: развитие биржевых механизмов привлечения инвестиций в инновационные компании; создание благоприятной среды для инвесторов и эмитентов; развитие взаимодействия с институтами развития.

Преимущества РИИ для компаний:

Привлечение инвесторов, нацеленных на компании данного типа

Позиционирование, возможность выделиться среди общего списка эмитентов

PR- и IR-поддержка со стороны биржи; инструменты поддержки от институтов развития ${ }^{15}$ (Pre-IPO финансирование, льготное кредитование).

Доступ к пенсионным накоплениям: в соответствии с Положением Банка России № 580-П до 5\% портфеля пенсионных накоплений НПФ

15 Институты развития и госкорпорации, в том числе Внешэкономбанк, госкорпорация «Роснанотех», госкорпорация «Фонд содействия реформированию жилищно-коммунального хозяйства», ОАО «Российская венчурная компания», ОАО «Росинфокоминвест», ОАО «Агентство по ипотечному жилищному кредитованию» и другие. 
может быть инвестировано в акции эмитентов, включенных в сегмент РИИ-Прайм (капитализация эмитента не менее 6 млрд. руб., включение в I или II уровень листинга, аудированная отчетность МСФО)

Налоговые льготы для инвесторов (исключение из налогооблагаемой базы по налогу на прибыль и НДФЛ доходов от реализации ценных бумаг российских эмитентов, включенных Перечень ценных бумаг высокотехнологичного (инновационного) сектора экономики)

\section{Критерии отбора компаний}

Для эмитентов акичии: капитализация эмитента - не менее 500 млн. рублей; эмитент соответствует критериям инновационности, а именно: осуществляет производство продукции, оказывает услуги, производит и (или) применяет технологии, входящие в перечень приоритетных направлений развития науки, технологий и техники в РФ, либо в перечень критических технологий РФ, утвержденных Указом Президента РФ от 07.07.2011 № 899; осуществляет инвестиции в инновационные и высокотехнологичные компании и проекты наноиндустрии; получил финансирование со стороны одной из следующих специализированных организаций/участвует в проектах: АО «РОСНАНО», АО «РВК» (фондов, сформированных АО «РВК»), Фонда «ВЭБ Инновации», Фонда «Сколково»; входит в реестр аккредитованных организаций, осуществляющих деятельность в области информационных технологий, раскрытие которого осуществляется на сайте Министерства цифрового развития, связи и массовых коммуникаций РФ в сети Интернет; осуществляет хозяйственную деятельность с применением инновационных технологий и подходов.

Для эмитентов облигаций: соответствие критериям инновационности (аналогично требованиям к эмитентам акций); наличие у эмитента (у выпуска облигаций) или у поручителя (гаранта) кредитного рейтинга одного из рейтинговых агентств.

Объем выпуска - не менее 1 млрд. руб.

Также для эмитентов акций и облигаций необходимо наличие заключения Экспертного совета РИИ (не представляется в случае получения эмитентом финансирования/участии в проектах $\mathrm{AO}$ «РОСНАНО», $\mathrm{AO}$ «РВК» (фондов, сформированных АО «РВК»), Фонда «ВЭБ Инновации», Фонда «Сколково»);

Для повышения уровня транспарентности эмитентов и снижения рисков инвесторов в Секторе РИИ действует институт листинговых агентов. Листинговый агент - аккредитованная биржей организация, 
которая по договору с эмитентом готовит Инвестиционный меморандум и заключение Листингового агента, содержащее обоснование оценки рыночной капитализации акций (по типовым формам). Наличие листингового агента обязательно для эмитентов акций, рыночная капитализация которых составляет менее 10 млрд. руб.

Государство планирует поддерживать и стимулировать «зеленые» проекты, для чего разрабатываются налоговые льготы и условия поддержки Банка России для инвесторов путем предоставления специальных условий резервирования. В мае 2019 г. Правительство РФ уже приняло Постановление о правилах предоставления субсидий на выплату купонного дохода в размере 70\% эмитентам облигаций, выпущенных в рамках реализации инвестиционных проектов по внедрению наилучших доступных технологий [107]. Субсидию смогут получить проекты, отвечающие определенным требованиям и прошедшие предварительный отбор, который будет проводиться не чаще двух раз в год. Реализация проектов должна способствовать «поэтапному достижению технологических норм допустимых выбросов и сбросов высокотоксичных веществ и веществ, обладающих канцерогенными и мутагенными свойствами» [121]. При этом общая сумма выпуска облигаций не может превышать 30 млрд. рублей. Постановление направлено на стимулирование и поддержку российских производителей и при использовании российского оборудования будет субсидироваться 90\% расходов компании на выплату купонного дохода. Компании, претендующие на получение субсидии, не должны иметь налоговой задолженности, находиться в процессе реструктуризации или банкротства. Иностранные компании и компании с более чем 50\% долей иностранного участия или размещенные на территории стран с льготным налоговым режимом или в офшорных зонах, не смогут получить субсидию.

Данные меры направлены на стимулирование развития «зеленого» финансирования в российской экономике и поддержку экологических проектов. Запланирована реализация следующих мер: модернизировать и перевести на принципы наилучших доступных технологий 300 российских предприятий, наносящих наибольший ущерб экологии России. Программа начнется уже в 2019 г., срок ее реализации до конца 2029 г., а до 2031 г. охватит уже 7000 предприятий. Объем средств на программу -8 трлн. руб. «Для предприятий - участников проекта внедрения НДТ предусмотрены меры господдержки - это 
льготы по оплате за негативное воздействие на окружающую среду, инвестиционные льготные кредиты, льготные кредиты и займы на приобретение оборудования. Также предусмотрено субсидирование процентных ставок по инвестиционным кредитам, ставки «купонного дохода» инвесторам по «зеленым облигациям», выпущенным в рамках реализации природоохранных проектов. Объем средств на субсидии по проекту НДТ планируется на уровне 0,3 млрд рублей в 2019 году, 3 млрд руб. в 2020 г. и 6 млрд рублей - в 2021 году» [121]. Данные меры реализуются в рамках национального проекта «Экология».

\section{Выводы}

Сложности и перспективы развития рынка зелёных облигаций в российской экономике проявляются в следующем:

- средний объем эмиссии облигаций - от 1 млрд. долл., в то время как проекты зеленых инвестиций требуют меньшие суммы - от 30 тыс. до 11 млн. долл., что делает экономически неэффективным эмиссию ценных бумаг под конкретный проект, поэтому эмитенты прибегают к выпуску секьюритизированных ценных бумаг. Это требует развития отлаженных механизмов секьюритизации и рынка секьюритизированных финансовых активов;

- для выпуска зеленых облигаций необходима процедура соответствия Принципам зеленых облигаций, раскрытие информации, составление дополнительной отчетности, что увеличивает затраты эмитента; необходимо отметить отсутствие достаточной нормативно-правовой базы для внедрения данных инструментов в российскую экономку в соответствии с международными стандартами;

- зеленые облигации находятся на начальной стадии своего развития не только в России, но и в мире (13 лет рынку зеленых финансовых инструментов), с связи с чем возможна неправильная оценка риска данных бумаг;

- 2019 год стал годом начала обращения первых сертифицированных российских зеленых финансовых инструментов (компания «Ресурсосбережение «ХМАО», Банк «Центр-Инвест», компания ООО «СФО Русол 1», АО «Коммерческая недвижимость ФПК «Гарант Инвест») и годом начала работы Сектора устойчивого развития Московской биржи, включающего три сегмента: «зеленые» облигации, «социальные» облигации и национальные проекты; 
- перспективы развития рынка хорошие, о чем говорит быстрый рост объемов рынка, присоединение к данному рынку компаний и государственных органов не только развитых, но и развивающихся стран (таких как Китай, Индия) осознание важности экологических проектов для страновых экономик и для мира в целом всеми стейкхолдерами. Поэтому у российского рынка хорошие шансы для внедрения зеленых финансовых инструментов и развития российского сегмента зеленых финансов. 


\title{
ГЛАВА 3. НАПРАВЛЕНИЯ СОВЕРШЕНСТВОВАНИЯ ИНСТРУМЕНТАРИЯ ФИНАНСИРОВАНИЯ ПРОЕКТОВ ЗЕЛЕНОЙ ЭКОНОМИКИ В РОССИЙСКОЙ ФЕДЕРАЦИИ
}

\author{
3.1. Роль и участие государства \\ в стимулировании зеленой экономики \\ и развитии рынка зеленого финансирования
}

Меры государственной поддержки зеленой экономики и рынка зеленого финансирования можно классифицировать по следующим группам:

1) по форме участие: прямое и косвенное;

2) по видам поддержки: административные и экономические (финансовые).

Среди административных мер выделим следующие:

- институциональные: формирование «контура поддержки» рынка зеленого финансирования (разработка и реализация стратегий, концепций, законодательных актов, формирующих, контролирующих, стимулирующих, регулирующих развитие зеленой экономики и зеленого финансирования) (анализ - см. пп.1.2, 2.2);

- организационные: организация, финансирование, стимулирование научно-исследовательской и аналитической работы по тематике зеленой экономики и финансов; снижение рисков посредством разработки соответствующих методических документов о классификации и оценке рисков;

Меры экономической (финансовой) поддержки зеленой экономики и финансов:

Прямые: стратегические выпуски облигаций с целью развития рынка, поддержания его ликвидности (выпуск суверенных и муниципальных облигаций, банковских облигаций); прямое государственное участие на этапах проектирования и подготовки проектов, субсидии, гранты; госзакупки с приоритетом экологических составляющих; снижение рисков посредством выпуска обеспеченных облигаций, секьюритизации ценных бумаг. 
Koсвенные: формирование системы льгот (экологические налоги и сборы, субсидирование процентных ставок, гарантии, государственное страхование, др.).

Развитие рынка зеленого финансирования в российской экономике вызвано рядом объективных причин (см. гл.1), оно вызывает как возможности, так и угрозы, игнорируя которые страна и компании могут терять свою конкурентоспособность (таблица 16).

Таблица 16

Возможности зеленой экономики и угрозы ее игнорирования

\begin{tabular}{|l|l|}
\hline \multicolumn{1}{|c|}{ Возможности } & \multicolumn{1}{|c|}{ Угрозы } \\
\hline - зеленые проекты расширяют возмож- & страны, не включенные в систему \\
ности привлечения инвестиций в страну & климатического регулирования, \\
и в проекты компаний; & и компании, игнорирующие тенден- \\
- факторы ESG все больше учитываются & ции развития зеленой экономики: \\
в рейтингах компаний, что оказывает вли- & - рискуют потерей конкурентоспо- \\
яние на конкурентоспособность бизнеса & собности, \\
и продукции, в т.Ч. на внешнеэкономическую & - увеличиваются риски роста внеш- \\
кооперацию и экспортные перспективы; & неторговых барьеров, \\
- увеличиваются стимулы разработки & - возрастают риски закрытия выгод- \\
и внедрения эко-проектов & ных источников финансирования \\
\hline
\end{tabular}

Источник: составлено автором.

В Российской Федерации реализуется комплекс мер, направленных на стимулирование внедрения зеленых технологий в экономике и развитие рынка зеленого финансирования (см. таблицу 17).

Таблица 17

Меры государственной поддержки зеленой экономики и рынка зеленого финансирования в Российской Федерации

\begin{tabular}{|l|l|}
\hline \multicolumn{1}{|c|}{ Содержание мер } & \multicolumn{1}{|c|}{ Нормативный акт / Примечания } \\
\hline \multicolumn{2}{|c|}{ Административные институциональные меры } \\
\hline - обязательность финансирования & Ф3 № 7 «Об охране окружающей среды» \\
юридическими лицами и индиви- \\
дуальными предпринимателями по- \\
следствий негативного воздействия \\
на окружающую среду (плата за не- \\
гативое воздействие на окружаю- \\
щую среду)
\end{tabular}


Продолжение табл. 17

\begin{tabular}{|c|c|}
\hline Содержание мер & Нормативный акт / Примечания \\
\hline $\begin{array}{l}\text { - разработка нормативно-правовых } \\
\text { актов, направленных на совершен- } \\
\text { ствование условий ведения бизнеса } \\
\text { в Российской Федерации в области } \\
\text { энергосбережения и повышения } \\
\text { энергетической эффективности }\end{array}$ & $\begin{array}{l}\text { Государственная программа Российской } \\
\text { Федерации «Экономическое развитие } \\
\text { и инновационная экономика» }\end{array}$ \\
\hline $\begin{array}{l}\text { - разработка и реализация программ, } \\
\text { направленных на улучшение эколо- } \\
\text { гических показателей и повышение } \\
\text { качества окружающей среды }\end{array}$ & $\begin{array}{l}\text { Национальный проект «Экология». Общий } \\
\text { объем финансирования - } 4041 \text { млрд. руб., } \\
\text { в т.ч. 701, } 2 \text { млрд. руб. - средства феде- } \\
\text { рального бюджета, 133,8 млрд. руб. - сред- } \\
\text { ства бюджетов субъектов РФ, 3206,1 млрд. } \\
\text { руб. - внебюджетные источники }\end{array}$ \\
\hline $\begin{array}{l}\text { - сформулированы цели экологиче- } \\
\text { ской политики, выделены основные } \\
\text { направления обеспечения экологи- } \\
\text { ческой безопасности экономическо- } \\
\text { го развития и улучшения экологиче- } \\
\text { ской среды жизни человека }\end{array}$ & $\begin{array}{l}\text { «Концепция долгосрочного социально- } \\
\text { экономического развития Российской Фе- } \\
\text { дерации на период до } 2020 \text { года» (распо- } \\
\text { ряжение Правительства РФ от 17.11.2008 } \\
\text { N 1662-р) }\end{array}$ \\
\hline \multirow[t]{2}{*}{$\begin{array}{l}\text { - утверждены приоритеты и цели } \\
\text { государственной политики в различ- } \\
\text { ных природных сферах }\end{array}$} & $\begin{array}{l}\text { Стратегия развития минерально-сырьевой } \\
\text { базы Российской Федерации до } 2035 \text { года, } \\
\text { утверждена распоряжением Правительства } \\
\text { Российской Федерации от } 22 \text { декабря } 2018 \\
\text { г. N 2914-р, Основы государственной по-- } \\
\text { литики в области использования минераль- } \\
\text { ного сырья и недропользования, утверж- } \\
\text { денными распоряжением Правительства } \\
\text { Российской Федерации от } 21 \text { апреля } 2003 \\
\text { г. N } 494-р, \text { Энергетическая стратегией Рос-- } \\
\text { сии на период до } 2030 \text { года, утвержденной } \\
\text { распоряжением Правительства Российской } \\
\text { Федерации от } 13 \text { ноября } 2009 \text { г. N 1715-р }\end{array}$ \\
\hline & $\begin{array}{l}\text { Постановление Правительства РФ «Об } \\
\text { утверждении государственной программы } \\
\text { Российской Федерации «Воспроизводство } \\
\text { и использование природных ресурсов» } \\
\text { от 15.04.2014 N } 322 \text { (ред. от 04.12.2019) } \\
\end{array}$ \\
\hline $\begin{array}{l}\text { - определены стратегическая цель, ос- } \\
\text { новные задачи государства в области } \\
\text { охраны окружающей среды и обеспе- } \\
\text { чения экологической безопасности } \\
\text { и механизмы их реализации. }\end{array}$ & $\begin{array}{l}\text { «Основы государственной политики в об- } \\
\text { ласти экологического развития Россий- } \\
\text { ской Федерации на период до } 2030 \text { года» } \\
\text { (утв. Президентом РФ } 30.04 .2012 \text { ) }\end{array}$ \\
\hline
\end{tabular}


Продолжение табл. 17

\begin{tabular}{|c|c|}
\hline Содержание мер & Нормативный акт / Примечания \\
\hline $\begin{array}{l}\text { - разработан ФЗ о публичной нефи- } \\
\text { нансовой отчётности и ключевые по- } \\
\text { казатели публичной нефинансовой } \\
\text { отчётности }\end{array}$ & $\begin{array}{l}\text { Проект Федерального закона «О публич- } \\
\text { ной нефинансовой отчетности», про- } \\
\text { ект Постановления Правительства РФ } \\
\text { «Об утверждении перечня ключевых } \\
\text { (базовых) показателей публичной не- } \\
\text { финансовой отчетности» (по состоянию } \\
\text { на 17.05.2019) (подготовлен Минэконом- } \\
\text { развития России). } \\
\text { Разработана совокупность экономиче- } \\
\text { ских, экологических и социальных пока- } \\
\text { зателей публичной нефинансовой отчёт- } \\
\text { ности. }\end{array}$ \\
\hline $\begin{array}{l}\text { - определено, что факторы измене- } \\
\text { ния климата оказывают существен- } \\
\text { ное влияние на экономическую без- } \\
\text { опасность государства }\end{array}$ & $\begin{array}{l}\text { Указ Президента РФ от } 13.05 .2017 \text { N } 208 \\
\text { «О Стратегии экономической безопас- } \\
\text { ности Российской Федерации на период } \\
\text { до } 2030 \text { года». }\end{array}$ \\
\hline \multicolumn{2}{|c|}{ Меры экономической (финансовой) поддержки: косвенные } \\
\hline \begin{tabular}{|l|} 
- предоставления налоговых льгот; \\
- предоставления льгот в отношении \\
платы за негативное воздействие \\
на окружающую среду в порядке; \\
\end{tabular} & $\begin{array}{l}\text { Ф3 № } 7 . \\
\text { Государственная поддержка осуществля- } \\
\text { ется при реализации мероприятий, опре- } \\
\text { деленных ст. } 17 \text { Ф3 № } 7\end{array}$ \\
\hline $\begin{array}{l}\text { - субсидии из федерального бюдже- } \\
\text { та российским организациям на ком- } \\
\text { пенсацию части затрат на уплату } \\
\text { процентов по кредитам, займам, } \\
\text { купонных доходов по облигациям, } \\
\text { полученным на реализацию ком- } \\
\text { плексных инвестиционных проек- } \\
\text { тов по приоритетным направлениям } \\
\text { гражданской промышленности. }\end{array}$ & $\begin{array}{l}\text { Постановление Правительства РФ } \\
\text { от 03.01.2014 № } 3 \text {. } \\
\text { Размер субсидии определяется в зависи- } \\
\text { мости от условий, определенных Поста- } \\
\text { новлением № } 702 \text {. }\end{array}$ \\
\hline - экологический сбор & $\begin{array}{l}\text { Постановление Правительства РФ } \\
\text { от } 08.10 .2015 \text { N } 1073 \text { «О порядке взима- } \\
\text { ния экологического сбора». Производи- } \\
\text { тели, импортеры товаров (включая упа- } \\
\text { ковку) обязаны обеспечивать выполнение } \\
\text { установленных Правительством РФ нор- } \\
\text { мативов утилизации. Производители, им- } \\
\text { портеры товаров, которые не обеспечива- } \\
\text { ют самостоятельную утилизацию отходов } \\
\text { от использования товаров, уплачивают } \\
\text { экологический сбор }\end{array}$ \\
\hline
\end{tabular}


Окончание табл. 17

\begin{tabular}{|c|c|}
\hline Содержание мер & Нормативный акт / Примечания \\
\hline $\begin{array}{l}\text { - субсидии из федерального бюд- } \\
\text { жета российским организациям } \\
\text { на возмещение затрат на выплату } \\
\text { купонного дохода по облигациям, } \\
\text { выпущенным в рамках реализации } \\
\text { инвестиционных проектов по вне- } \\
\text { дрению наилучших доступных тех- } \\
\text { нологий }\end{array}$ & $\begin{array}{l}\text { Постановление Правительства РФ } \\
\text { от 30.04.2019 N 541 }\end{array}$ \\
\hline $\begin{array}{l}\text { - платежи за негативное воздействие } \\
\text { на окружающую среду }\end{array}$ & $\begin{array}{l}\text { Статья 16. Плата за негативное воздей- } \\
\text { ствие на окружающую среду, Ф3 № } 7 .\end{array}$ \\
\hline \multicolumn{2}{|c|}{ Меры экономической (финансовой) поддержки: прямые } \\
\hline $\begin{array}{l}\text { - выделение средств федерального } \\
\text { бюджета и бюджетов субъектов Рос- } \\
\text { сийской Федерации }\end{array}$ & $\begin{array}{l}\text { Государственная поддержка осуществля- } \\
\text { ется при реализации мероприятий, опре- } \\
\text { деленных ст. } 17 \text { ФЗ № } 7 .\end{array}$ \\
\hline
\end{tabular}

Источник: составлено автором.

Рассмотрим меры стимулирования экологических проектов и «зеленых» инструментов финансирования подробнее:

В Российской Федерации реализуются 12 национальных проектов, в числе которых Нацииональный проект «Экология» [122]. В рамках данного проекта предусмотрены цели, целевые показатели и объемы финансирования мероприятий программы. Целями проекта является улучшение экологических показателей, таких как:

- Эффективное обращение с отходами производства и потребления, включая ликвидацию всех выявленных на 1 января 2018 г. несанкционированных свалок в границах городов.

- Снижение уровня загрязнения атмосферного воздуха в крупных промышленных центрах, в том числе уменьшение не менее чем на 20 процентов совокупного объема выбросов загрязняющих веществ в атмосферный воздух в наиболее загрязненных городах.

- Повышение качества питьевой воды для населения, в том числе для жителей населенных пунктов, не оборудованных современными системами централизованного водоснабжения.

- Экологическое оздоровление водных объектов, включая реку Волгу, и сохранение уникальных водных систем, включая озера Байкал и Телецкое. 
- Сохранение биологического разнообразия, в том числе посредством создания не менее 24 новых особо охраняемых природных территорий.

Обеспечение баланса выбытия и воспроизводства лесов в соотношении $100 \%$ к 2024 г.

Общий объем финансирования - 4041 млрд. руб., в т.ч. 701, 2 млрд. руб. - средства федерального бюджета, 133,8 млрд. руб. - средства бюджетов субъектов РФ, 3206,1 млрд. руб. - внебюджетные источники [122].

В Концепции долгосрочного социально-экономического развития Российской Федерации на период до 2020 год [123] сформулирован» цель экологической политики - «значительное улучшение качества природной среды и экологических условий жизни человека, формирование сбалансированной экологически ориентированной модели развития экономики и экологически конкурентоспособных производств. Успешная реализация Россией программы экологического развития является важнейшим вкладом России в сохранение глобального биосферного потенциала и поддержание глобального экологического равновесия» [123].

Климатическая доктрина Российской Федераџии была утверждена в 2009 г. [124] и предписывает Правительству РФ «при проведении государственной политики Российской Федерации по вопросам, связанным с возможным глобальным и региональным изменением климата и его последствиями, руководствоваться положениями» этой доктрины [124]. Среди принципов Климатической доктрины РФ - принципы учета глобальных интересов России в отношении изменения климата и их последствий и приоритет национальных интересов России при разработке и реализации политики в области климата.

Еще один основополагающий документ - Стратегия экономической безопасности Российской Федераџии на период до 2030 г. [125]. В документе отмечается, что «на состояние экономической безопасности существенное влияние начинают оказывать факторы, связанные с глобальным изменением климата», а одним из 25 ключевых вызовов и угроз является «установление избыточных требований в области экологической безопасности, рост затрат на обеспечение экологических стандартов производства и потребления» [125].

«Основы государственной политики в области экологического развития Российской Федерации на период до 2030 года» (утв. Президентом РФ 30.04.2012) [126] определяют стратегическую цель, основные задачи государства в области охраны окружающей среды и обе- 
спечения экологической безопасности и механизмы их реализации. Согласно документу «стратегической целью государственной политики в области экологического развития является решение социальноэкономических задач, обеспечивающих экологически ориентированный рост экономики, сохранение благоприятной окружающей среды, биологического разнообразия и природных ресурсов для удовлетворения потребностей нынешнего и будущих поколений, реализации права каждого человека на благоприятную окружающую среду, укрепления правопорядка в области охраны окружающей среды и обеспечения экологической безопасности» [126].

Распоряжение Правительства РФ от 18.12.2012 N 2423-р (ред. от 10.08.2016) «Об утверждении Плана действий по реализаџии Основ государственной политики в области экологического развития Российской Федерации на период до 2030 года» [127] предусматривает разработку публичной нефинансовой отчётности и ее показателей. Проект Федерального закона «О публичной нефинансовой отчетности» подготовлен Минэкономразвития России в конце 2017 г., но не принят до настоящего времени (08.01.2019). Также разработаны, но не утверждены ключевые показатели публичной нефинансовой отчетности [10]. В проекте предлагаются следующие экологические показатели: объем использованной свежей воды из всех источников водоснабжения, объем оборотного и повторно-последовательного водоснабжения, объем сброса загрязненных сточных вод в поверхностные водные объекты, образовано отходов I - IV классов опасности за отчетный период всего, обращение с отходами I - IV классов опасности, масса выбросов загрязняющих веществ в атмосферный воздух от стационарных источников, выбросы парниковых газов, затраты на охрану окружающую среду.

Обязательность финансирования юридическими лицами и индивидуальными предпринимателями последствий негативного воздействия на окружающую среду (плата за негативное воздействие на окружающую среду) (ст. 16.1, Ф3 № 7) [30]. «Плата за негативное воздействие на окружающую среду взимается за следующие его виды:

- выбросы загрязняющих веществ в атмосферный воздух стационарными источниками;

- сбросы загрязняющих веществ в водные объекты;

- хранение, захоронение отходов производства и потребления» (ст. 16, Ф3 № 7). 
Ф3 № 7 «Об охране окружающей средыл» определяет меры стимулирующего воздействия за реализацию мероприятий, направленных на снижение вреда окружающей среде и внедрения наилучших доступных технологий (НДТ):

1) введение дифференцированных коэффициентов, применяемых при исчислении платы за негативное воздействие на окружающую среду, платы за негативное воздействие на окружающую среду при размещении отходов (ст. 5,6 Ф3 № 7) (значения коэффициентов от 0 до 100) [30].

2) снижение суммы платы за негативное воздействие на окружающую среду при реализации мероприятий по снижению негативного воздействия на окружающую среду на величину затрат на эти мероприятия (ст. 11 Ф3 №7);

3) предоставления налоговых льгот;

4) предоставления льгот в отношении платы за негативное воздействие на окружающую среду;

5) выделения средств федерального бюджета и бюджетов субъектов Российской Федерации в соответствии с бюджетным законодательством Российской Федерации (ст. 17 Ф3 № 7).

Государственная поддержка осуществляется при реализации следующих мероприятий (ст. 17 ФЗ № 7):

1) внедрение наилучших доступных технологий;

2) проектирование, строительство, реконструкция: систем оборотного и бессточного водоснабжения; централизованных систем водоотведения (канализации), канализационных сетей, локальных (для отдельных объектов хозяйственной и (или) иной деятельности) сооружений и устройств по очистке сточных, в том числе дренажных, вод, по переработке жидких бытовых отходов и осадка сточных вод; сооружений и установок по улавливанию и утилизации выбрасываемых загрязняющих веществ, термической обработке и очистке газов перед их выбросом в атмосферный воздух;

3) установка: оборудования по улучшению режимов сжигания топлива; оборудования по использованию, транспортированию, обезвреживанию отходов производства и потребления; автоматизированных систем, лабораторий по контролю за составом, объемом или массой сточных вод; автоматизированных систем, лабораторий (стационарных и передвижных) по контролю за составом загрязняющих веществ и объемом или массой их выбросов в атмосферный воздух; автомати- 
зированных систем, лабораторий (стационарных и передвижных) по наблюдению за состоянием окружающей среды, в том числе компонентов природной среды;

4) обеспечение полезного использования попутного нефтяного газа.

В соответствии с законодательством применяются и санкционные меры, так за несоблюдение нормативов может быть пересчитана плата с применением коэффициента 100 (ст. 9 Ф3 № .7).

Постановление Правительства РФ от 03.01.2014 N 3 (ред. от 01.08.2019) [128] регулирует правила предоставления субсидий из федерального бюджета российским организациям на возмещение части затрат на уплату процентов по кредитам, полученным в 2014 - 2019 годах на реализацию комплексных инвестиционных проектов по приоритетным направлениям гражданской промышленности и (или) выплату купонного дохода по облигациям, выпущенным в 2014 - 2019 годах в рамках реализации комплексных инвестиционных проектов по приоритетным направлениям гражданской промышленности. Цель предоставления субсидий - снижение затрат на обслуживание организациями долговых обязательств, связанных с реализацией данных инвестиционных проектов. Одними из таких приоритетных инвестиционных проектов являются проекты по «созданию новых экономически эффективных и экологически безопасных производств (для предоставления субсидий по кредитам, полученным в 2014 - 2016 годах), созданию новых экономически эффективных производств и внедрению принципов наилучших доступных технологий на производстве» (ст. 3 Постановления № 3). Отметим, что субсидии предоставляются не только по кредитам, но и по выпущенным облигациям для целей реализации приоритетных, в т.ч. экологических, проектов. Размер субсидий может составлять 0,7 базового индикатора, если процентная ставка больше или равна базовому индикатору и 70\% затрат на уплату процентов по кредиту, если процентная ставка меньше базового индикатора (по кредитам 2017-2019 гг.). Базовый индикатор (БИ) рассчитывается в соответствии с Постановление Правительства РФ от 20.07.2016 N 702 [129]. Он является заменой ставок рефинансирования Центрального банка Российской Федерации и ключевой ставки Центрального банка Российской Федерации, применяемых при расчете параметров субсидирования процентной ставки за счет средств федерального бюджета по кредитам, облигационным 
займам и (или) договорам лизинга и определяется как сумма показателей ключевой ставки Центрального банка Российской Федерации и значения кривой бескупонной доходности облигаций федерального займа со сроком погашения 10 лет с учетом корректирующих коэффициентов по формуле (1) [129]:

$$
\text { БИ }=\text { КС } \times \mathrm{K} 1+\mathrm{O} Ф 3 \times \mathrm{K} 2,
$$

где КС - показатель ключевой ставки Центрального банка Российской Федерации; ОФЗ - значение кривой бескупонной доходности облигаций федерального займа (со сроком погашения 10 лет); К1 и К2 - корректирующие коэффициенты, в сумме равные 1.

При расчете базового индикатора при расчете параметров субсидирования процентной ставки за счет средств федерального бюджета по кредитам, облигационным займам и (или) договорам лизинга, предоставленным на срок до 10 лет, применяются корректирующие коэффициенты К1 и К2, рассчитываемые по следующим формулам (2) и (3):

$$
\begin{gathered}
\text { К1 = (3650 дней - срок кредита } \\
\text { (займа, лизинга) в днях) / } 3650 \text { дней }
\end{gathered}
$$

где срок кредита (займа, лизинга) - период времени (в днях) с момента заключения договора о выдаче кредита, предоставления облигационного займа, оформления в лизинг, до даты завершения его действия;

$$
\mathrm{K} 2=1-\mathrm{K} 1 .
$$

При расчете базового индикатора при расчете параметров субсидирования процентной ставки за счет средств федерального бюджета по кредитам, облигационным займам и (или) договорам лизинга, предоставленным на срок свыше 10 лет, применяются корректирующие коэффициенты с величинами К $1=0$ и К $2=1$.

Кроме базового индикатора рассчитывается предельный уровень конечной ставки кредитования, предоставления облигационного займа, имущества по договору лизинга, исчисляемый в процентном выражении, при превышении которого субсидирование процентной ставки не осуществляется (ПУ), который определяется по формуле (4) [129, ст. 6]:

$$
\Pi \mathrm{Y}=\mathrm{KC} \times \mathrm{KC} 1+\mathrm{O} Ф 3 \times \mathrm{K} 2+9,
$$

где для субсидирования процентной ставки по кредитам, облигационным займам и (или) договорам лизинга, предоставленным на срок 
до 10 лет, применяются корректирующие коэффициенты К1 и К2 (п.4 Правил № 702, формулы 2 и 3); для субсидирования процентной ставки по долгосрочным кредитам, облигационным займам и (или) договорам лизинга, предоставленным на срок свыше 10 лет, применяются корректирующие коэффициенты К $1=0$ и К $2=1$, установленные в соответствии с п. 5 Правил № 702.

Субсидии по кредитам, полученным в 2014 - 2016 годах в валюте Российской Федерации, предоставляются в размере 70 процентов суммы затрат организации на уплату процентов по кредиту, за исключением процентов, начисленных и уплаченных по просроченной ссудной задолженности. При этом размер субсидии не может превышать величину, рассчитанную исходя из 0,7 ключевой ставки Центрального банка Российской Федерации, действующей на дату уплаты процентов по кредиту.

Субсидии по кредитам, полученным в 2014 - 2016 годах в иностранной валюте, а также субсидии по кредитам, полученным в 2017 - 2019 годах в иностранной валюте, предоставляются в рублях из расчета 90 процентов размера затрат организации на уплату процентов по кредиту в расчетном периоде исходя из курса иностранной валюты по отношению к рублю, установленного Центральным банком Российской Федерации на дату осуществления указанных затрат, за исключением процентов, начисленных и уплаченных по просроченной ссудной задолженности. При этом размер предоставляемой субсидии не может превышать величину, рассчитанную исходя из ставки по кредиту, полученному в иностранной валюте, в размере 4 процента годовых. Субсидии на возмещение процентов, начисленных и уплаченных по просроченной ссудной задолженности, не предоставляются.

Субсидии по облигациям, номинированным в валюте Российской Федерации, предоставляются в размере 70 процентов суммы фактических затрат организации на выплату купонного дохода по облигационным займам. При этом размер субсидии не может превышать величину, определенную исходя из 70 процентов базового индикатора. Субсидии не предоставляются на возмещение процентов, начисленных и уплаченных по кредитам, и (или) на возмещение купонного дохода по облигациям, ставка по которым превышает предельный уровень конечной ставки кредитования, предоставления облигационного займа, определяемый в соответствии с постановлением N 702. 
В федеральном бюджете на реализацию такого механизма господдержки предусмотрены средства в размере 24,05 млрд. руб., в т.ч. в 2018 6,85 млрд. руб., 2019 - 8,6 млрд. руб., 2020 - 8,59 млрд. руб.

Еще одно аналогичное Постановление Правительства РФ принято в апреле 2019 (№ 541) и направлено на возмещение затрат по купонным доходам облигаций, выпущенных в рамках реализации инвестиционных проектов по внедрению наилучших доступных технологий [107]. Субсидии, согласно данному Постановлению, предоставляются по облигациям, выпущенным после 01 января 2019 г. в рамках реализации инвестиционных проектов НДТ, в т.ч. на объектах, оказывающих значительное негативное воздействие на окружающую среду и относящихся к областям применения НДТ. При этом общая стоимость выпуска облигаций должна составлять до 30 млрд. рублей. Размер субсидии - 70\% от суммы фактических затрат на выплату купона по облигациям, но не более $70 \%$ величины базового индикатора, определенного в соответствии с Постановлением № 792.

С целью поддержки отечественных производителей, Постановление № 541 предусматривает увеличение субсидии до 90\% фактических затрат на выплату купонного дохода по облигациям (но не более 90\% базового индикатора) при условии приобретения в рамках инвестиционного проекта промышленной продукции, соответствующей Постановлению № 719 [130].

В настоящее время существуют намерения Правительства Российской Федерации изменить систему платежей за негативное воздействие на окружающую среду и заменить ее экологическим налогом. Министерство финансов РФ разработало проект изменений в Налоговый кодекс РФ и планирует внести новую главу Экологический налог [131]. Министерство финансов РФ отмечает снижение сумм по экологическому сбору и платежей за негативное воздействие на окружающую среду («поступления от платы за негативное воздействие на окружающую среду в консолидированный бюджет в 2017 году составили 14,2 млрд рублей. На 2018 год указанные поступления запланированы на уровне 11,6 млрд рублей, на 2019 и 2020 годы 10,3 млрд рублей соответственно» [131])и планирует существенный рост поступлений от экологического налога по сравнению с экологическими платежами, $5 \%$ поступлений предполагается направлять в доход Федерального бюджета, 95\% - в доход бюджета субъекта Российской Федерации. Основные элементы предлагаемого налога представлены в таблице 18. 


\section{Основные элементы экологического налога}

\begin{tabular}{|c|c|}
\hline Элемент & Характеристика \\
\hline Налогоплательщики & $\begin{array}{l}\text { - организации и физические лица, оказывающие негатив- } \\
\text { ное воздействие на окружающую среду, признаваемое объ- } \\
\text { ектом налогообложения; } \\
\text { - организации и физические лица, при хозяйственной } \\
\text { и иной деятельности которых образуются отходы; } \\
\text { - региональные и иные операторы по обращению с тверды- } \\
\text { ми коммунальными отходами. }\end{array}$ \\
\hline \multirow[t]{2}{*}{$\begin{array}{l}\text { Объект } \\
\text { налогообложения }\end{array}$} & $\begin{array}{l}\text { Негативное воздействие на окружающую среду в результате: } \\
\text { - выбросы в атмосферу загрязняющих веществ от стацио- } \\
\text { нарных источников (по списку); }\end{array}$ \\
\hline & $\begin{array}{l}\text { - сброса в водные объекты сточных вод веществ, включен- } \\
\text { ные в список загрязняющих; } \\
\text { - образования, хранения, захоронения, накопления, разме- } \\
\text { щения отходов производства и потребления (по классам } \\
\text { опасности). }\end{array}$ \\
\hline Налоговая база & $\begin{array}{l}\text { - объем или масса выбросов в атмосферу загрязняющих } \\
\text { веществ; } \\
\text { - объем или масса фактически образованных и размещен- } \\
\text { ных отходов производства. }\end{array}$ \\
\hline $\begin{array}{l}\text { Особенности } \\
\text { определения } \\
\text { налоговой базы }\end{array}$ & $\begin{array}{l}\text { При определении налоговой базы учитываются: } \\
\text { - объем или масса выбросов загрязняющих веществ в пре- } \\
\text { делах норматив допустимых выбросов, сбросов; } \\
\text { - объем или масса выбросов загрязняющих веществ в пре- } \\
\text { делах лимитов на выбросы, сбросы; } \\
\text { - объем или масса выбросов загрязняющих веществ, пре- } \\
\text { вышающие нормативы и лимиты допустимых выбросов, } \\
\text { сбросов; } \\
\text { - лимиты на размещение отходов производства и потребле- } \\
\text { ния и их превышение. }\end{array}$ \\
\hline Налоговые ставки & $\begin{array}{l}\text { - налоговые ставки устанавливаются по видам загрязня- } \\
\text { ющих веществ и классу опасности отходов производства } \\
\text { и потребления; } \\
\text { - налоговые ставки увеличиваются для территорий и объ- } \\
\text { ектов, находящихся под особой охраной (коэффициент 2); } \\
\text { - налоговые ставки корректируются при осуществлении на- } \\
\text { логоплательщиком мероприятий по снижению негативных } \\
\text { воздействий на окружающую среду и внедрения наилуч- } \\
\text { ших доступных технологий (коэффициента от } 0 \text { до 100). }\end{array}$ \\
\hline
\end{tabular}

Источник: разработано автором на основе [131]. 
Минфин РФ, обосновывает необходимость введения экологического налога следующими аргументами:

- необходимость «финансового обеспечения деятельности Правительства Российской Федерации, связанной с проведением государственной политики в области экологии;

- низкая эффективностью взимания неналоговых платежей, о чем говорит, по мнению Минфина, снижение в динамике поступлений за негативное воздействие на окружающую среду;

- отсутствием должной мотивации у плательщиков экологических неналоговых платежей к правомерному поведению в форму уплаты платы за негативное воздействие на окружающую среду. Минфин объясняет это тем, что «неуплата экологических неналоговых платежей не образует состава преступления, предусмотренного УК РФ» [131].

- замена экологических неналоговых платежей экологическим налогом позволит увеличить объём доходов бюджетов за счет лучшего администрирования налога посредством применения мер налоговой. административной и уголовной ответственности, механизмов принудительного и бесспорного взыскания.

Предложения по внедрению экологического налога получили неоднозначную оценку со стороны экспертного сообщества и ученых. Так, Бобошко Н.М., д-р экон. наук, профессор МосУ МВД России им. В.Я. Кикотя считает, что предлагаемый налог может быть эффективен с точке зрения создания условий для неухудшения экологической ситуации в стране, прогрессивные ставки налогообложения стимулируют налогоплательщиков к снижению вредного воздействия на окружающую среду. В тоже время он отмечает, что налог может быть перенесен на конечного потребителя, путем включения сумм налога в затраты [132].

Непроработанность и несбалансированность проекта экологического налога отмечают Филичева Т.П. (канд. геогр. наук, доцент кафедры экономики и управления Владивостокского государственного университета экономики и сервиса) и Горкина И.Д. (канд. геогр. наук, ведущий консультант Центра инноваций и высоких технологий «Концепт») [133]. Исследователи отмечают, что Конституционный суд РФ (2002) в своем определении отметил компенсационный характер экологических платежей, а также подчеркнул, что такие платежи являются формой возмещения последствий негативного воздействия [132], а данный признак отсутствует у налоговых платежей. Отметим, что 
ранее в российской истории (1991-2001 гг.) природоохранные платежи осуществлялись всеми хозяйствующими субъектами за счет прибыли, остающейся в распоряжении организаций, и поступали в экологический (государственный внебюджетный) фонд. Средства экологического фонда носили целевой характер и использовались на выполнение природоохранных мероприятий. Экологический фонд был ликвидирован в 2001 г.

Рассмотрим подробнее аргументы Минфина о необходимости замены экологических неналоговых платежей экологическим налогом.

Тезис о неэффективности неналоговых платежей ввиду снижения объемов поступления не вполне корректен. Это объясняется тем, что факторами снижения объемов платежей является уменьшение выбросов и загрязнений, стимулировать которое призван платеж.

Также отметим, что природоохранные платежи должны использоваться на выполнение природоохранных мероприятий, в то время как налоговые платежи не носят целевого характера, следовательно при замене природоохранных платежей экологическим налогом снижаются стимулы для финансирования природоохранной деятельности.

Тезис Минфина о лучшем налоговом администрировании требует анализа данных о динамике экологических правонарушений и уклонении пользователей от внесения платы за негативное воздействие на окружающую среду, в Пояснительной записке к проекту федерального закона «О внесении изменений в части первую и вторую Налогового кодекса Российской Федерации» эти данные отсутствуют, что не позволяет говорить о корректности выводов. Снижение поступление от природоохранных платежей объясняется реализацией организациями экологических проектов, направленных на уменьшение вредного воздействия на окружающую среду. Кроме того, расходы на природоохранные мероприятия снижают суммы природоохранных платежей. В проекте экологического налога сумма налога также может уменьшена на фактическую сумму расходов на природоохранные мероприятия, но не более, чем $70 \%$ начисленной суммы налога.

В настоящее время организация, внося плату за вредное воздействие на окружающую среду, уменьшает размер причиненного экологического ущерба и отказывается от требований полного возмещения затрат на покрытие экологического ущерба. В случае перевода платежей за сбросы, выбросы загрязняющих веществ, захоронение отходов и другие виды вредного воздействия на окружающую среду в статус 
налогов, происходит переход к безвозмездным платежам (налог - это, по свое сути, безвозмездный платеж), что может привести к росту требований о полном покрытии экологического ущерба организациями без учета уплаченных сумм экологического налога. Это приведет к росту административной и финансовой нагрузки на бизнес и ухудшению условий его работы.

В финансово-экономическом обосновании проекта экологического налога отмечается, что «принятие федерального закона «О внесении изменений в части первую и вторую Налогового кодекса Российской Федерации» не потребует дополнительных финансовых средств из бюджета». Но налоговое администрирование предлагаемого налога требует усложнения процедуры по сравнению с действующей системой: так, предполагается введение в процедуры нового участника Росприроднадзора, который будет подтверждать достоверность информации организаций об объемах негативного воздействия на окружающую среду, что увеличивает объем работы специалистов и может потребовать дополнительных затрат.

Таким образом, в случае принятия экологического налога в предлагаемой редакции, наблюдается противоречие между целями увеличения сумм налоговых платежей для роста доходов бюджетов и целями снижения объемов загрязнений окружающей среды, что снижает эффективность государственной политики в сфере природоохранной деятельности. Требуется тщательное обоснование перевода природоохранных платежей в экологический налог.

\section{Выводы}

Уточнена классификация мер государственной поддержки по классификационным признакам: по форме участия (прямая и косвенная поддержка) и по видам поддержки (административные и экономические (финансовые)) и выделены применяемые меры поддержки в российской экономике. К административным мерам отнесены институциональные меры (формирование «контура» поддержки рынка зеленого финансирования), организационные (организация научно-исследовательской работы по тематике зеленых финансов и экономики и разработка методических документов по классификации и оценке рисков). К мерам экономической (финансовой) поддержки относятся прямые меры (выпуск государственных и муниципальных облигаций, субсидии, гранты, госзакупки и др.) и косвенные (экологические на- 
логи и сборы, субсидирование процентных ставок, гарантии, государственное страхование и др.).

Сформулированы возможности зеленой экономики и угрозы ее игнорирования. К возможностям относятся: расширение возможностей привлечение инвестиций, повышение/сохранение конкурентоспособности компаний и продукции, в т.ч. во внешнеэкономических коммуникациях, увеличение стимулов разработки новых инновационных технологий (наилучших доступных технологий - НДТ). Среди угроз игнорирования зеленой экономики отнесем следующие: потеря конкурентоспособности компаний и продукции, рост рисков внешнеторговых барьеров, риск закрытия финансовых рынков).

Анализ мер государственной поддержки эко-проектов в российской экономике показал наличие мер как прямой, так и косвенной поддержки, направленной на поддержки и стимулирование экологических проектов и снижение вреда окружающей среде от хозяйственной деятельности экономических субъектов:

- разработаны налоговые льготы для инвесторов, реализующих проекты природоохранной направленности;

- действует система экологических сборов и платежей за НВОС (негативное воздействие на окружающую среду), направленная на компенсацию вреда окружающей среде и стимулирование уменьшения вредных выбросов, государством предлагаются меры по модернизации данной системы (внедрение экологического налога), которые находятся в настоящее время ${ }^{11}$ на стадии обсуждения;

- реализуются субсидии на возмещение затрат на выплату купонного дохода по облигациям, выпущенным в рамках реализации инвестиционных проектов по внедрению наилучших и доступных технологий;

- разработаны и реализуются меры поддержки эмитентов ценных бумаг, целевая направленность которых (ценных бумаг) связана с инвестированием в эко-проекты, в инновационные проекты, среди которых выделим финансовые меры:

- если эмитент - субъект МСП: субсидии и компенсации субъектам МСП, поручительства/гарантии по облигационным выпускам от Корпорации МСП, участие МСП-Банка в размещении облигаций эмитентов МСП, сниженные требования листинга по free-float;

\footnotetext{
${ }^{11}$ Ha 20.10.2020.
} 
- если компания инвестирует в инновационные проекты: инструменты поддержки от институтов развития (Pre-IPO финансирование, льготное кредитование), возможно инвестирование со стороны негосударственных пенсионных фондов, налоговые льготы для инвесторов;

- если компания инвестирует в проекты НДТ (наилучших доступных технологий): субсидии на выплату купонного дохода в размере $70 \%$.

Таким образом, в российской экономике сложилась и действует система мер поддержки и стимулирования проектов в области зеленой экономики, дальнейшими направлениями модернизации которой должны стать: совершенствование системы налоговых платежей и сборов, оценка эффективности действующих мер.

\section{2. Оценка эколого-экономического риска российских регионов}

Считаем, что при выпуске инструментов финансирования экологических проектов (например, «зеленых» облигаций) целесообразно учитывать на какой территории реализуются проекты и для обоснования рейтинга ценных бумаг рассчитывать риски эколого-экономического состояния регионов. В качестве меры рисков предлагаем учитывать рейтинг «эколого-экономического риска» регионов, расчет которого предложен автором ${ }^{12}$ и представлен им в работах $[134,135]$ и Приложении Г. Значение данного показателя определяет рейтинг ценных бумаг и характеризует риск инвестирования в региональные экологическое проекты. Соотношение значение рейтинга «экологоэкономического риска» регионов и рейтинга ценных бумаг представлено в таблице 19.

Сравнивая данные анализа с исследованием, проведенным коллективом ученых (Бобылев С.Н. и др., 2012) [137] по расчету эколого-экономического рейтинга регионов на основе показателя «скорректированные чистые накопления», отметим, что лидеры и аутсайдеры рейтинга не совпадают, за исключением Кемеровской области. По нашему мнению, разница в результатах вызвана следующими обстоятельствами:

- расчет эколого-экономического рейтинга регионов проводился за один период (2012 г.), в то время как рейтинг эколого-экономическо-

\footnotetext{
${ }^{12}$ Совместно с Аникиной И.Д.
} 
го риска регионов отражает данные за длительный период (пять периодов), что позволяет учесть инерционность экономических процессов;

- эколого-экономический рейтинг не позволяет дать однозначную оценку эффективности управленческих решений относительно реализации эколого-экономической политики региона: так, добывающие регионы с низким показателем рейтинга являются донорами бюджетов других территорий, при этом на собственной территории может не обеспечиваться воспроизводство природных ресурсов.

Та блиц а 19

Шкала рейтинга «зеленых» источников финансирования ${ }^{13}$

\begin{tabular}{|c|c|l|}
\hline $\begin{array}{c}\text { Рейтинг «эколого- } \\
\text { экономического } \\
\text { риска» регионов }\end{array}$ & $\begin{array}{c}\text { Рейтинговая шкала } \\
\text { «зеленых» } \\
\text { ценных бумаг }\end{array}$ & \multicolumn{1}{|c|}{$\begin{array}{c}\text { Характеристика } \\
\text { рейтинговй шкалы }\end{array}$} \\
\hline$[1 \div 2[$ & $\mathrm{A}+$ & $\begin{array}{l}\text { Низкий уровень риска. Регион } \\
\text { характеризуется высоким потен- } \\
\text { циалом экономического развития } \\
\text { при снижающемся уровне экологи- } \\
\text { ческой нагрузки. }\end{array}$ \\
\hline$[2 \div 3[$ & А & $\begin{array}{l}\text { Удовлетворительный уровень ри- } \\
\text { ска. Характерно экономическое раз- } \\
\text { витие региона при меньшем росте } \\
\text { экологической нагрузки. }\end{array}$ \\
\hline$[3 \div 4[$ & В+ & $\begin{array}{l}\text { Приемлемый уровень экологическо- } \\
\text { го риска. Регион характеризуется } \\
\text { снижением экономического разви- } \\
\text { тия. Но и антропогенная нагрузка } \\
\text { на окружающую среду снижается. }\end{array}$ \\
\hline$[4 \div 5[$ & В & $\begin{array}{l}\text { Высокий уровень риска. Экономи- } \\
\text { ческий рост в регионе отсутствует } \\
\text { при снижении экологической на- } \\
\text { грузки. }\end{array}$ \\
\hline & С & $\begin{array}{l}\text { Очень высокий уровень риска. Сни- } \\
\text { жение экономический показателей } \\
\text { сопровождается ростом экологиче- } \\
\text { ской нагрузки в регионе. }\end{array}$ \\
\hline
\end{tabular}

Источник: составлено автором.

13 За основу взята национальная шкала рейтинга облигаций рейтингового агентства «Эксперт РА» [136]. 
Исследование показало (см. таблицы 20,21), что почти половина российских регионов имеют рейтинг $\mathrm{B}+(46,24 \%)$ и относятся к приемлемому уровню эколого-экономического риска.

Таблица 20

Ранжирование регионов по уровню «эколого-экономического риска»

\begin{tabular}{|l|l|}
\hline $\begin{array}{l}\text { Pейтинг эколого- } \\
\text { экономического } \\
\text { риска регионов }\end{array}$ & \multicolumn{1}{|c|}{ Регионы } \\
\hline A + & $\begin{array}{l}\text { Липецкая область, Тульская область, Архангельская область, } \\
\text { Белгородская область, Вологодская область, Иркутская об- } \\
\text { ласть, Курская область, Новгородская область, Свердловская } \\
\text { область }\end{array}$ \\
\hline А & $\begin{array}{l}\text { Ульяновская область, Челябинская область, Республика Саха } \\
\text { (Якутия), Республика Мордовия, Мурманская область } \\
\text { Красноярский край, Удмуртская Республика, Саратовская об-- } \\
\text { ласть, Республика Тыва, Хабаровский край, Владимирская } \\
\text { область, Чеченская Республика, Ростовская область, Чуваш- } \\
\text { ская Республика - Чувашия, Воронежская область, Москов- } \\
\text { ская область, Брянская область, Ярославская область, Респу- } \\
\text { блика Марий Эл, Ленинградская область, Сахалинская } \\
\text { область, Республика Калмыкия, Орловская область, Тверская } \\
\text { область, Новосибирская область }\end{array}$ \\
\hline В+ & $\begin{array}{l}\text { Костромская область, Город Москва, Республика Татарстан } \\
\text { (Татарстан), Псковская область, Самарская область, Томская } \\
\text { область, Магаданская область, Ивановская область, Калинин-- } \\
\text { градская область, Республика Хакасия, Карачаево-Черкесская } \\
\text { Республика, Камчатский край, Астраханская область, Курган- } \\
\text { ская область, Республика Карелия, Республика Коми, Нижего- } \\
\text { родская область, Республика Башкортостан, Тамбовская об- } \\
\text { ласть, Омская область, Пермский край, Республика Северная } \\
\text { Осетия-Алания, Республика Алтай, Чукотский автономный } \\
\text { округ, Калужская область, Кировская область, Кабардино-Бал- } \\
\text { карская Республика, Волгоградская область, Смоленская об-- } \\
\text { ласть, Город Санкт-Петербург, Забайкальский край, Республи-- } \\
\text { ка Бурятия, Республика Дагестан, Ставропольский край, } \\
\text { Тюменская область, Амурская область, Рязанская область }\end{array}$ \\
\hline В & $\begin{array}{l}\text { Республика Адыгея, Алтайский край, Приморский Край, Ре-- } \\
\text { спублика Ингушетия, Краснодарский край, Пензенская об-- } \\
\text { ласть, Оренбургская область, Еврейская автономная область, } \\
\text { Кемеровская область }\end{array}$ \\
\hline
\end{tabular}

Источник: расчеты автора. 
Глава 3

Таблица 21

Рейтинг «эколого-экономического риска»
федеральных округов РФ

\begin{tabular}{|c|c|c|c|c|c|c|c|}
\hline & & $\mathbf{A}+$ & $\mathbf{A}$ & $\mathbf{B}+$ & $\mathbf{B}$ & $\mathbf{C}$ & Итого \\
\hline \multirow{2}{*}{ РФ } & $\mathbf{g}$ & 9 & 25 & 37 & 9 & 0 & 80 \\
\cline { 2 - 8 } & $\mathbf{\%}$ & 11,25 & 31,25 & 46,25 & 11,25 & 0,00 & 100,00 \\
\hline \multirow{2}{*}{ ЦФО } & $\mathbf{g}$ & 4 & 7 & 7 & 0 & 0 & 18 \\
\cline { 2 - 8 } & $\mathbf{\%}$ & 22,22 & 38,89 & 38,89 & 0,00 & 0,00 & 100,00 \\
\hline \multirow{2}{*}{ СЗФО } & $\mathbf{g}$ & 3 & 2 & 5 & 0 & 0 & 10 \\
\cline { 2 - 8 } & $\mathbf{\%}$ & 30,00 & 20,00 & 50,00 & 0,00 & 0,00 & 100,00 \\
\hline \multirow{2}{*}{ ЮФО } & $\mathbf{g}$ & 0 & 2 & 2 & 2 & 0 & 6 \\
\cline { 2 - 8 } & $\mathbf{\%}$ & 0,00 & 33,33 & 33,33 & 33,33 & 0,00 & 100,00 \\
\hline \multirow{2}{*}{ СКФО } & $\mathbf{g}$ & 0 & 1 & 5 & 1 & 0 & 7 \\
\cline { 2 - 8 } & $\mathbf{\%}$ & 0,00 & 14,29 & 71,43 & 14,28 & 0,00 & 100,00 \\
\hline \multirow{2}{*}{ ПФО } & $\mathbf{g}$ & 0 & 6 & 6 & 2 & 0 & 14 \\
\cline { 2 - 8 } & $\mathbf{\%}$ & 0,00 & 42,86 & 42,86 & 14,28 & 0,00 & 100,00 \\
\hline \multirow{2}{*}{ УФО } & $\mathbf{g}$ & 1 & 1 & 2 & 0 & 0 & 4 \\
\cline { 2 - 8 } & $\mathbf{\%}$ & 25,00 & 25,00 & 50,00 & 0,00 & 0,00 & 100,00 \\
\hline \multirow{2}{*}{ СФО } & $\mathbf{g}$ & 1 & 3 & 6 & 2 & 0 & 12 \\
\cline { 2 - 8 } & $\mathbf{\%}$ & 8,33 & 25,00 & 50,00 & 16,67 & 0,00 & 100,00 \\
\hline \multirow{2}{*}{ ДФО } & $\mathbf{g}$ & 0 & 3 & 4 & 2 & 0 & 9 \\
\cline { 2 - 8 } & $\mathbf{\%}$ & 0,00 & 33,33 & 44,45 & 22,22 & 0,00 & 100,00 \\
\hline
\end{tabular}

Примечания: при анализе регионов использовались данные Территориальных отделений Росстата с учетом: УФО: Тюменская область с автономными округами (Ханты-Мансийский автономный округ-Югра, Ямало-Ненецкий автономный округ); СЗФО: Архангельская область с Ненецким автономным округом; ЮФО: без Крыма и г. Севастополь ввиду отсутствия данных за весь анализируемый период; ДФО: Камчатский край, включая Корякский округ, $\mathrm{g}$ - количество регионов в группе.

Источник: расчеты автора.

Низкий уровень риска имеют $11,25 \%$ регионов, удовлетворительный - 31,25\%, высокий уровень риска - 11,25\%, в последнюю группу с очень высоким уровнем риска не попал ни один регион. Рассма- 
тривая регионы с низким уровнем эколого-экономического риска (рейтинг $\mathrm{A}+$ ), следует отметить, что из 9 регионов в группе восемь принадлежат к промышленным регионам и только один (Курская область) входит в группу аграрно-промышленных регионов. Среди 9 регионов в группе с высоким уровнем риска (рейтинг В) семь относятся в аграрно-промышленным регионам и два (Приморский край и Кемеровская область) - в группу промышленных регионов.

Таблица 22

Характеристика эффекта декаплинга

\begin{tabular}{|l|c|c|c|c|c|c|c|}
\hline \multicolumn{1}{|c|}{ Год } & $\mathbf{2 0 1 0}$ & $\mathbf{2 0 1 1}$ & $\mathbf{2 0 1 2}$ & $\mathbf{2 0 1 3}$ & $\mathbf{2 0 1 4}$ & $\mathbf{2 0 1 5}$ & $\mathbf{2 0 1 6}$ \\
\hline \multicolumn{7}{|c|}{ Липецкая область, Rеeа $=1,14$} \\
\hline $\mathrm{R}_{1}$,тыс. т & 367,630 & 344,910 & 338,750 & 346,680 & 330,000 & 327,690 & 320,360 \\
\hline $\mathrm{R}_{1}$ тчел & 0,312 & 0,294 & 0,291 & 0,298 & 0,284 & 0,283 & 0,277 \\
\hline$\Delta \mathrm{R}_{1}$, отн. ед. & - & $-0,058$ & $-0,013$ & 0,027 & $-0,046$ & $-0,005$ & $-0,021$ \\
\hline TҮ, отн. ед & 1,044 & 1,053 & 1,022 & 1,037 & 1,053 & 1,012 & 1,017 \\
\hline$\Delta$ ТY, отн. ед. & - & 0,053 & 0,022 & 0,037 & 0,053 & 0,012 & 0,017 \\
\hline $\begin{array}{l}\text { Сектор } \\
\text { (по } \mathrm{R}_{1} \text { ) }\end{array}$ & - & 1 & 1 & 2 & 1 & 1 & 1 \\
\hline \multicolumn{7}{|c|}{ Кемеровская область, Rеeа $=4,71$} \\
\hline $\mathrm{R}_{1}$,тыс. т & 1410,650 & 1390,030 & 1360,360 & 1356,300 & 1331,690 & 1344,460 & 1349,480 \\
\hline $\mathrm{R} 1$ т/чел & 0,509 & 0,503 & 0,494 & 0,495 & 0,487 & 0,493 & 0,496 \\
\hline$\Delta \mathrm{R}_{1}$, отн. ед. & - & $-0,010$ & $-0,018$ & 0,000 & $-0,015$ & 0,013 & 0,006 \\
\hline ТҮ, отн. ед & 1,030 & 1,027 & 0,961 & 0,963 & 1,024 & 0,993 & 0,973 \\
\hline$\Delta$ ТҮ, отн. ед. & - & 0,027 & $-0,039$ & $-0,037$ & 0,024 & $-0,007$ & $-0,027$ \\
\hline $\begin{array}{l}\text { Сектор } \\
\text { (по } \mathrm{R}_{1} \text { ) }\end{array}$ & - & 1 & 5 & 6 & 1 & 6 & 6 \\
\hline
\end{tabular}

Примечание: ТY - индекс физического объема ВРП на душу населения, отн. ед.; $\Delta$ TY - темп прироста физического объема ВРП на душу населения отн. ед.; R1 - выбросы загрязняющих веществ от стационарных источников, тыс. тонн; R1 т/чел. - выбросы загрязняющих веществ от стационарных источников на душу населения; $\Delta \mathrm{R} 1$ - темп прироста R1 на душу населения, отн. ед.; сектор (по R1) сектор, характеризующий эффект декаплинга по модели декаплинг-анализа; Reea - рейтинг эколого-экономического риска региона.

Источник: расчеты автора по данным [139]. 
Оценивая такое распределение регионов, следует подчеркнуть, что сельское хозяйство оказывает большое влияние на состояние окружающей среды: «более 75\% пресной воды используется для нужд сельского хозяйства, включая животноводство, около 25\% участков суши занято под пастбища, производство продовольственных растительных культур выросло с 1970 г. на 300\%» [138]. Деление регионов на экспортно-ориентированные, промышленные и аграрно-промышленные приведено в работе Бобылева С.Н. и др. [137, с. 34-35].

Лидером рейтинга является Липецкая область, а аутсайдером рейтинга оказалась Кемеровская область. Сравнение регионов приведено в таблице 22.

Декаплинг-анализ показал, что Липецкая область на протяжении анализируемого периода в 83,33\% имеет снижение выбросов загрязняющих веществ от стационарных источников на душу населения при росте ВРП на душу населения во всех периодах анализа, что характеризует абсолютный эффект декаплинга в 83,33\% случаях наблюдений. Данная ситуация является наиболее благоприятной с точки зрения эколого-экономического состояния региона и характеризуется снижением экологической нагрузки в регионе при одновременном экономическом росте. В Кемеровской области 50\% наблюдений показывают рост выбросов загрязняющих веществ от стационарных источников на душу населения, при этом ВПР на душу населения снижается в 66,67\% случаях. Декаплинг-анализ показал, что область в половине из анализируемых периодах находится в наихудшем секторе, когда рост нагрузки на экологию региона сопровождается ухудшением экономической ситуации.

\section{Выводы}

Сложности и перспективы развития рынка зелёных облигаций в российской экономике проявляются в следующем:

- средний объем эмиссии облигаций - от 1млрд. долл., в то время как проекты зеленых инвестиций требуют меньшие суммы - от 30 тыс. до 11 млн. долл., что делает экономически неэффективным эмиссию ценных бумаг под конкретный проект, поэтому эмитенты прибегают к выпуску секьюритизированных ценных бумаг. Это требует развития отлаженных механизмов секьюритизации и рынка секьюритизированных финансовых активов; 
- для выпуска зеленых облигаций необходима процедура соответствия Принципам зеленых облигаций, раскрытие информации, составление дополнительной отчетности, что увеличивает затраты эмитента; необходимо отметить отсутствие достаточной нормативно-правовой базы для внедрения данных инструментов в российскую экономку в соответствии с международными стандартами;

- зеленые облигации находятся на начальной стадии своего развития не только в России, но и в мире (13 лет рынку зеленых финансовых инструментов), с связи с чем возможна неправильная оценка риска данных бумаг;

- рынок зеленого финансирования развивается быстрыми темпами: расширяется спектр финансовых инструментов: появились и находят своего инвестора такие инструменты как «голубые» облигации, «зеленые» секьюритизированные кредиты; возникают новые институциональные фонды, поддерживающие не только крупные, но и средние компании;

- перспективы развития рынка хорошие, о чем говорит быстрый рост объемов рынка, присоединение к данному рынку компаний и государственных органов не только развитых, но и развивающихся стран (Китай, Индия), осознание важности экологических проектов для страновых экономик и для мира в целом всеми стейкхолдерами. Поэтому у российского рынка хорошие шансы для внедрения зеленых финансовых инструментов и развития российского сегмента зеленых финансов;

- для оценки эколого-экономического риска инвестирования в «зеленые» ценные бумаги предложена шкала рейтинга ценных бумаг на основе значений рейтинга «эколого-экономического риска» регионов и рассчитан рейтинг для российских регионов. 


\section{ЗАКЛЮЧЕНИЕ}

Поведённое исследование позволило сделать следующие выводы и дать рекомендации:

1. Проведен анализ нормативно-информационного обеспечения сферы регулирования вопросов климатической политики и изучены базовые международные соглашения (Рамочная конвенция ООН по изменению климата, Киотский протокол, Киото-2, Парижские соглашения). Показаны механизмы мирового уровня по охране окружающей среды и сложности их претворения на практике. Рассмотрена политика России в области глобальной экологической повестки, охарактеризованы российские нормативные документы и проекты в сфере охраны окружающей среды. Исследованы различные позиции относительно возможных вариантов экологической стратегии России. Сформулированы риски процессов реализации климатических соглашений для российской экономики: рост себестоимости углеродного топлива, невысокое развитие возобновляемых источников энергии, увеличение рисков технологического отставания российской экономики, высокая неопределённость в понимании механизмов и направлений дельнейшей реализации Парижских соглашений. Проведен анализ стран с высокими запасами угля на предмет развития альтернативной энергетики. Рассмотрены жесткие и мягкие механизмы реализации Парижских соглашений и сделан вывод о том, что при конкретизации механизмов и инструментов экологической политики необходим учет специфики российской экономики, особенностей климата, уровня технологического и технического развития, наличия и количества и качества природных ресурсов, а также политические факторы.

2. Систематизированы факторы формирования источников финансирования экологических проектов по критериям: экзогенные (макрои мезо-) факторы, эндогенные (корпоративные) факторы, эндогенные факторы экологического проекта. Проанализированы особенности зеленого финансирования Международными финансовыми институтами, такими как Зеленый климатический фонд, Глобальный экологический фонд, Группа Всемирного банка, Европейский банк Реконструкции и развития, Климатические инвестиционные фонды. Рассмотрена правовая специфика выпуска «зеленых» облигаций в соответствии с «Принципа- 
ми зеленых облигаций». Проведен анализ мирового рынка «зеленых облигаций» и выявлены тенденции его развития, характеризующие рынок ростом объемов сделок, более широким применением новаций. Сформулированы сложности развития рынка зелёных облигаций в российской экономике, к которым относятся: экономически неэффективная эмиссия ценных бумаг под отдельный экологический проект ввиду разницы между значительным объемом выпуска ценных бумаг на фондовом рынке и необходимо меньшим объемом инвестиций для конкретного проекта; отсутствие достаточной нормативно-правовой базы для внедрения инструментов «зеленого финансирования» в российскую экономку в соответствии с международными стандартами; сложность оценки риска «зеленых» ценных бумаг, вызванная краткостью истории исследуемого сегмента рынка. Сделан вывод о перспективности внедрения «зеленых облигаций» в российской экономике.

3. Проанализирована основные события и документы, направленные на становление и развития рынка ответственного финансирования в 2019 г. Отметим, что в 2019 г. начал развиваться «зеленый» сектор на Московской бирже. Были размещены первые выпуски «зеленых» облигаций как компаний реального сектора экономики, так и финансовых институтов: компании «Ресурсосбережение «ХМАО», Банка «Центр-Инвест», компании ООО «СФО Русол 1», АО «Коммерческая недвижимость ФПК «Гарант Инвест». В Секторе устойчивого развития Московской биржи котируются облигации банка «Центр-Инвест» и компании $\mathrm{AO}$ «Коммерческая недвижимость ФПК «Гарант-Инвест».

4. Факторы формирования источников финансирования экологических проектов целесообразно классифицировать по группам: экзогенные (макро- и мезо-факторы), оказывающие влияние на формирование инвестиционной стратегии компании /инвестора; эндогенные корпоративные факторы, учитывающие специфические факторы компании / инвестора и ESG-факторы, а также эндогенные факторы экологических проектов, учитывающие вклад эко-проектов в изменение стоимости компании. Среди экзогенных факторов выделен фактор экологоэкономического состояния региона, который предлагается оценивать на основе декаплинг-анализа. Учет ESG - факторов предлагается вести на основе анализа показателей: экологических, социальных, управленческих. Эндогенные факторы экологического проекта, помимо традиционных показателей, применяемых при оценке, должны учитывать экологическую, социальную, политическую значимость проекта. 
5. Проведен анализ мер государственной поддержки проектов зеленой экономики в России. Анализ показал наличие сложившейся системы мер поддержки и стимулирования эко-проектов, как административных, так и экономических (финансовых), прямых и косвенных. Данная системы мер эволюционирует и модернизируется: так только в 2019 г. разработаны и реализуются меры поддержки эмитентов ценных бумаг, целевая направленность которых (ценных бумаг) связана с инвестированием в эко-проекты (субсидии на возмещение затрат на выплату купонного дохода по облигациям, выпущенным в рамках реализации инвестиционных проектов по внедрению наилучших и доступных технологий), разработан и проходит стадию обсуждения проект внесения в Налоговый Кодекс Российской Федерации статьи «Экологический налог». Это свидетельствует об актуальности экологической проблематики в российской экономике и необходимости дальнейших исследований в данной области.

6. С целью оценки эколого-экономического риска инвестирования в «зеленые» ценные бумаги автором предложена шкала рейтинга ценных бумаг на основе значений рейтинга «эколого-экономического риска» регионов и рассчитан рейтинг для 80 российских регионов по данным за 2012-2016 гг., проведено ранжирование регионов по уровню эколого-экономического риска, сделаны выводы о целесообразности учета изменения эколого-экономического риска региона для целей оценки эффективности проводимой региональной экологоэкономической политики. 


\section{СПИСОК ИСПОЛЬЗОВАННЫХ ИСТОЧНИКОВ}

\section{Глава 1}

1. Данные по показателям ЦУР // Росстат: сайт. - URL: https://www. gks.ru/sdg/data (дата обращения: 02.01.2020).

2. Концепция организации в России методологической системы по развитию зеленых финансовых инструментов и проектов ответственного инвестирования // Экспертный совет по рынку долгосрочных инвестиций при Банке России. М., 2019. 87 c. - URL: http://www.cbr.ru/Content/ Document/File/84163/press_04102019.pdf (дата обращения: 01.01.2020).

3. Sustainable finance // European Commission: сайт. - URL: https://ec. europa.eu/info/business-economy-euro/banking-and-finance/green-finance_ en\#hleg (дата обращения: 03.01.2020).

4. TEG report on EU taxonomy. - URL: https://ec.europa.eu/info/ files/190618-sustainable-finance-teg-report-taxonomy_en (дата обращения: 03.01.2020).

5. 19 декабря 2018 г. ООО «РСБ ХМАО» получило Независимое заключение о выпуске зеленых облигаций (Green Bond Second Opinion) от рейтингового агентства Rating-Agentur Expert RA GmbH* о соответствии проектов, финансируемых компанией, Принципам зеленых облигаций (Green Bond Principles 2018 ICMA)». Цитировано по: Компании «Ресурсосбережение XMAO»: сайт. - URL: http://www.rsb-hmao.ru/ zelenoe-finansirovanie (дата обращения: 05.01.2020).

6. Московская биржа: сайт. - URL: https://www.moex.com/s3019 (дата обращения: 05.01.2020).

7. «31. Обеспечить скорейший запуск механизма «зелёных» облигаций, позволяющего повысить привлекательность российских и иностранных прямых инвестиций и снизить стоимость заёмных средств при реализации проектов экологической направленности». Цитировано по: Перечень поручений по итогам расширенного заседания президиума Государственного совета. // Президент России: сайт. - URL: http://kremlin.ru/acts/ assignments/orders/59450 (дата обращения: 05.01.2020).

8. Политический форум высокого уровня по устойчивому развитию (HLPF) 2020. // Центра компетенций по взаимодействию с международ- 
ными организациями ВШЭ сайт. - URL: https:/globalcentre.hse.ru/ announcements/326496240.html (дата обращения: 05.01.2020).

9. Проект Федерального закона «О публичной нефинансовой отчетности» // КонсультантПлюс: сайт. - URL: http://www.consultant.ru/cons/cgi/ online.cgi?req $=$ doc $\&$ base $=$ PRJ\&n $=167355 \&$ dst $=\# 05714209808229878$ (дата обращения: 06.01.2020).

10. Проект Постановления Правительства РФ «Об утверждении перечня ключевых (базовых) показателей публичной нефинансовой отчетности» (по состоянию на 17.05.2019) (подготовлен Минэкономразвития России) // КонсультантПлюс: сайт. - URL: http://www.consultant.ru/cons/ cgi/online. cgi? req $=$ doc $\&$ ts $=1220835955003344427124358296 \&$ cacheid $=E 448$ 103365427AD54E20897878D5F97F \&mode $=$ splus \&base $=$ PNPA\& $n=47551 \& \mathrm{r}$ nd=C8A6B3C3CFCE0FCCFA04167A26975C74\#1tfdwm2saso (дата обращения: 06.01.2020).

11. Политический форум высокого уровня по устойчивому развитию (HLPF) 2020 // Центра компетенций по взаимодействию с международными организациями ВШЭ: сайт. - URL: https://globalcentre.hse.ru/ announcements/326496240.html (дата обращения: 05.01.2020).

12. РСПП: сайт. - URL: http://pспп.pф/simplepage/natsionalnyy-registri-biblioteka-korporativnykh-nefinansovykh-otchetov/ (дата обращения: 05.01.2020).

13. Минфин: сайт. - URL: https://www.minfin.ru/ru/perfomance/ international/cooperation/G20/green/ (дата обращения: 05.01.2020).

14. Зеленые финансы: повестка дня для России: диагностическая записка. Экспертный совет по рынку долгосрочных инвестиций при Банке России. М., 2018, 64 с.

15. Правительство России: сайт. - URL: http://government.ru/ rugovclassifier/section/2641/ (дата обращения: 05.01.2020).

16. ООН: сайт. - URL: https://www.un.org/sustainabledevelopment/ru/ sustainable-development-goals/ (дата обращения: 05.01.2020)

17. Зеленые облигации - растет рынок экологических финансовых инструментов // EENERGY.MEDIA -информационно-отраслевой ресурс: сайт. - URL: http://eenergy.media/2017/10/03/zelenye-obligatsii-rastet-rynokekologicheskih-finansovyh-instrumentov/ (дата обращения: 05.07.2018).

18. Рекомендации в области устойчивого развития и зеленых инвестиций. М., 2018. 10 с. // НАКДИ: сайт. - URL: https://investinfra.ru/ (дата обращения: 05.01.2020). 
19. Зеленое финансирование» в России: создание возможностей для «зеленых» инвестиций. Аналитическая записка. Группа Всемирного банка. М., 2018. 127 с. // Всемирный банк: сайт. - URL: http://documents.worldbank.org/ curated/en/699051540925687477/pdf/131516-RUSSIAN-PN-P168296-P164837PUBLIC-Green-finance-Note.pdf (дата обращения: 04.01.2020).

20. Аникин, А. А. Концепция устойчивого экономического роста как базис для принятия управленческих решений в современной экономике / А. А. Аникин // Научный форум: Экономика и менеджмент: сб. ст. по материалам XXXIII междунар. науч.-практ. конф. М.: Изд-во «МЦНО», 2019. № 10 (33). 58 c. C. 17-23. - URL: https://nauchforum.ru/conf/economy/ xxxiii (дата обращения: 01.01.2020).

21. Глобальный зеленый новый курс. Доклад, март 2009 г. Издано Программой $\mathrm{OOH}$ по окружающей среде в рамках Инициативы по зеленой экономике. - URL: http://www.unepcom.ru/images/greeneconomy/ greennewdeal.pdf. (дата обращения: 30.12.2018).

22. Рамочная конвенция Организации Объединенных Наций об изменении климата. Принята 9 мая 1992 года. - URL: https://www.un.org/ru/ documents/decl_conv/conventions/climate_framework_conv.shtml. (дата обращения: 10.09.2018)

23. Киотский протокол к Рамочной конвенции Организации Объединенных Наций об изменении климата. - URL: https://www.un.org/ru/ documents/decl_conv/conventions/kyoto.shtml. (дата обращения: 10.09.2018)

24. TACC: сайт. - URL: https://tass.ru/info/2297422 (дата обращения: 01.05.2019).

25. Вестник отделения наук о Земле PAH: сайт. - URL: https://onznews. wdcb.ru/images/news16/. (дата обращения: 01.05.2019).

26. Frankfurter Allgemeine: Москва не хочет присоединяться к договоpy Киото-2 // Deutsche Welle: сайт. 2012/ - 20 ноября. - URL: https://www. dw.com/ru/frankfurter-allgemeine-москва-не-хочет-присоединяться-кдоговору-киото-2/a-16408103 (дата обращения: 01.05.2019).

27. Парижское соглашение. - URL: https://treaties.un.org/doc/ Treaties/2016/02/20160215\%2006-03\%20PM/Ch_XXVII-7-d.pdf.

28. ООН: сайт. - URL: https://www.un.org/sustainabledevelopment/ru/ climate-change/. (дата обращения: 01.05.2019).

29. Указ Президента РФ от 01.04.1996 N 440 «О Концепции перехода Российской Федерации к устойчивому развитию». КонсультантПлюс: сайт. - URL: http://www.consultant.ru/cons/cgi/online.cgi?req=doc;base=EXP ;n=233558\#0893137186763888. (дата обращения: 03.05.2019). 
30. Федеральный закон от 10.01.2002 N 7-Ф3 (ред. от 29.07.2018) «Об охране окружающей среды». КонсультатнПлюс: сайт. - URL: http:// www.consultant.ru/cons/cgi/online.cgi? req $=$ doc\&base $=$ LAW \&n $=301549 \&$ fld $=$ $134 \& \mathrm{dst}=1000000001,0 \& \mathrm{rnd}=0.5121512642566695 \# 09260422738630374$ (дата обращения: 03.05.2019).

31. Международное энергетическое агентство: сайт. - URL: https:// webstore.iea.org/co2-emissions-from-fuel-combustion-2018-highlights. (дата обращения: 03.05.2019).

32. Проект Федерального закона «О государственном регулировании выбросов парниковых газов и о внесении изменений в отдельные законодательные акты Российской Федерации». КонсультантПлюс: сайт. - URL: https://regulation.gov.ru/projects/List/AdvancedSearch\#kinds $=6 \&$ StartDate $=7$. 12.2018\&EndDate=7.12.2018\&nрa=86521 1 (дата обращения: 03.05.2019).

33. Степанова М.А., Гаврильева Т.Н. Российская климатическая политика после Парижского соглашения: перспективы северных регионов // Экономика Востока России. 2018. № 1 (09). С. 97-106.

34. План реализации комплекса мер по совершенствованию государственного регулирования выбросов парниковых газов и подготовки к ратификации Парижского соглашения, принятого 12 декабря 2015 г. 21-й сессией Конференции Сторон Рамочной конвенции Организации Объединенных Наций об изменении климата. Распоряжение Правительства Российской Федерации от 3 ноября 2016 г. N 2344-p.

35. Минприроды РФ: сайт. - URL: http://www.mnr.gov.ru/press/news/ minprirody_rossii_podgotovilo_i_vneslo_v_pravitelstvo_rf_predlozheniya_s_ obosnovaniem_tselesoobrazno/. (дата обращения: 03.05.2019).

36. Парижскому соглашению РСПП не мешает // Газета «Коммерсантъ» №13 от 25.01.2019. С. 2 // Коммерсант»: сайт. - URL: https://www. kommersant.ru/doc/3862151 (дата обращения: 03.05.2019).

35. Проект Федерального закона «О государственном регулировании выбросов парниковых газов и о внесении изменений в отдельные законодательные акты Российской Федерации». Правительство России: сайт. URL: https://regulation.gov.ru/projects/List/AdvancedSearch\#kinds=6\&StartD ate $=7.12 .2018 \&$ EndDate $=7.12 .2018 \& n p a=865211$.

36. Приказ Минприроды России от 30.06.2015 N 300 «Об утверждении методических указаний и руководства по количественному определению объема выбросов парниковых газов организациями, осуществляющими хозяйственную и иную деятельность в Российской Федерации» (Зарегистрировано в Минюсте России 15.12.2015 N 40098) // Консультант- 
Плюс: сайт. - URL: http://www.consultant.ru/cons/cgi/online.cgi?req=doc\&b ase $=\mathrm{LAW} \& \mathrm{n}=190838 \& \mathrm{fld}=134 \& \mathrm{dst}=1000000001,0 \& \mathrm{rnd}=0.241851315089$ 49387\#09545703212195382. (дата обращения: 01.06.2019).

37. Приказ Минприроды России от 11.10.2018 N 509 «Об утверждении формы декларации о воздействии на окружающую среду и порядка ее заполнения, в том числе в форме электронного документа, подписанного усиленной квалифицированной электронной подписью» (Зарегистрировано в Минюсте России 10.12.2018 N 52926 // Консультант Плюс: сайт. - URL: https://rulaws.ru/acts/Prikaz-Minprirody-Rossii-ot11.10.2018-N-509/.

38. Приказ Минприроды России от 11.10.2018 N 510 «Об утверждении формы заявки на получение комплексного экологического разрешения и формы комплексного экологического разрешения» (Зарегистрировано в Минюсте России 10.12.2018 N 52927) // КонсультантПлюс: сайт. URL: https://rulaws.ru/acts/Prikaz-Minprirody-Rossii-ot-11.10.2018-N-510/ (дата обращения: 01.06.2019).

39. Отделение международной некоммерческой организации Greenpeace в России: сайт. - URL: https://greenpeace.ru/news/2019/03/19/ minprirody-vystupilo-za-ratifikaciju-parizhskogo-soglashenija/ (дата обращения: 01.10.2019).

40. Информационный портал «Будущее России. Национальные проекты»: сайт. - URL: https://futurerussia.gov.ru/nacionalnye-proekty/srocnomedvedev-podpisal-postanovlenie-svazannoe-s-prinatiem-rf-parizskogosoglasenia-po-klimatu (дата обращения: 01.10.2019).

41. Давыдова А. Россия согласилась на Парижский климат // Коммерсантъ. № 173. 24.09.2019.

42. В 2017 году доля угля в выбросах СО2 составила 45\% (1 место). Данные независимой информационно-консалтинговой компании Enerdata. - URL: https://yearbook.enerdata.ru/co2-fuel-combustion/CO2emissions-data-from-fuel-combustion.html. (дата обращения: 01.06.2019).

43. Рахманкулов Д.Л., Николаева С.В., Латыпова Ф.Н., Вильданов Ф.Ш., Шавшукова С.Ю. Мировые запасы угля и перспективы его использования // Башкирский химический журнал. 2009. Том 16. № 2. С. 21-28.

44. Статистический сборник мировой энергетики 2018. - URL: https:// yearbook.enerdata.ru/co2-fuel-combustion/world-CO2-intensity.html (дата обращения: 01.06.2019).

45. Vivareit: сайт. - URL: https://vivareit.ru/strany-lidery-po-zapasamuglya/ (дата обращения: 03.06.2019). 
46. Соколов А.Д., Такайшвили Л.Н. Оценка ресурсов угля восточных регионов России для строительства угольных электростанций // Вестник Иркутского государственного технического университета. 2018. Т. 22. № 7. C. 155-163. DOI: 10.21285/1814-3520-2018-7-155-163.

47. Краткое содержание и основные положения доклада «Риски реализации Парижского климатического соглашения для экономики и национальной безопасности» // Институт проблем естественных монополий. M., 2016. 22 c. - URL: http://ipem.ru/files/files/other/kratkoe_soderzhanie_i_ osnovnye_polozheniya_doklada_riski_realizacii_parizhskogo_klimatiches kogo_soglasheniya_dlya_ekonomiki_i_nacionalnoy_bezopasnosti_rossii.pdf (дата обращения: 01.01.2019).

48. Росстат: сайт. - URL: https://rosstat.gov.ru/folder/11193 (дата обращения: 20.10.2020).

49. Данные независимой информационно-консалтинговой компании Enerdata. - URL: https://yearbook.enerdata.ru/renewables/renewable-inelectricity-production-share.html (дата обращения: 02.01.2020).

50. «Сдерживающими факторами переориентации сырьевой базы производства жидких топлив с нефти на уголь до настоящего времени являлись, в основном, экономические и экологические факторы, которые удалось устранить применением разработанной в России уникальной каталитической системы, что позволило существенно снизить технологическое давление, и привлечением атомной энергетики». Цит по: 43, с. 27.

51. Аналитический доклад «Риски реализации Парижского климатического соглашения для экономики и национальной безопасности» // Институт проблем естественных монополий. М., 2016. 114 с.

52. Постановление Правительства РФ от 15.04.2014 N 316 (ред. от 24.12.2019) «Об утверждении государственной программы Российской Федерации «Экономическое развитие и инновационная экономика» (с изм. и доп., вступ. в силу с 01.01.2020) - URL: http://www.consultant.ru/ cons/cgi/online.cgi?req $=$ doc\&ts $=1220835955003344427124358296 \&$ cacheid $=$ 8D0F3081DD90D216FAA1D06BB7CD1CFD\&mode $=$ splus\&base $=$ LAW \&n $=$ $342157 \& \mathrm{dst}=129179 \& \mathrm{rnd}=\mathrm{C} 8 \mathrm{~A} 6 \mathrm{~B} 3 \mathrm{C} 3 \mathrm{CFCE} 0 \mathrm{FCCFA04167A26975C74 \# 261}$ duyah41v (дата обращения: 03.06.2019).

53. Паспорт подпрограммы Д «Энергосбережение и повышение энергетической эффективности» государственной программы Российской Федерации «Экономическое развитие и инновационная экономика» (введен Постановлением Правительства РФ от 29.03.2019 N 379). - URL: http:// www.consultant.ru/document/cons_doc_LAW_162191/9ca0eadc6bfc50b5426 991d690cc8f12fbb13a2e/. (дата обращения: 03.06.2019). 


\section{Глава 2}

54. «Эколого-экономическое развитие регионов: совершенствование методологии и методики оценки»: коллективная монография / Аникина И.Д., Аникин А.А. / под ред. Аникиной И.Д. Федер. гос. авт. образоват. учреждение высш. образования «Волгогр. гос.ун-т». Волгоград: Изд-во ВолГУ, 2019. 196 с.

55. Указ Президента Российской Федерации от 07.05.2018 г. № 204 «О национальных целях и стратегических задачах развития Российской Федерации на период до 2024 года». Президент России: сайт. - URL: http://kremlin.ru/acts/bank/43027 (дата обращения: 01.05.2019).

56. Необходимая финансовая система. Отчет об исследовании ЮНЕП «Развитие финансовой системы с учетом устойчивого развития». Октябрь 2015. - URL: http://unepinquiry.org/wp-content/uploads/2015/10/The Financial_System_We_Need_RU.pdf (дата обращения: 05.05.2019).

57. ЛИВЕНЬ. Living Asia - онлайн-экожурнал: сайт. - URL: http:// livingasia.online/2017/12/20/klimaticheskoe_finansirovanie/ (дата обращения: 05.05.2019).

58. Зеленый климатический фонд: сайт. - URL: https://www. greenclimate.fund/home (дата обращения: 08.05.2019).

59. Глобальный экологический фонд: сайт. - URL: https://www.thegef. org/ (дата обращения: 08.05.2019).

60. Всемирный банк: сайт. - URL: http://www.worldbank.org/ (дата обращения: 08.05.2019).

61. European Investment Bank: сайт. - URL: http://www.eib.org/en/ (дата обращения: 08.09.2019).

62. Финансирование экологических проектов: презентация на основе Руководства по стратегическим и финансовым решениям в поддержку экологически безопасного, низкоуглеродного и климатически устойчивого развития Программы развития ООН и материалов Зеленого климатического фонда. - URL: https://alatransit.kz/sites/default/files/3_e.suleymenov_finansirovanie_ekologicheskih_proektov.pdf (дата обращения: 08.09.2019); Всемирный банк: сайт. - URL: http://www.worldbank.org/ (дата обращения: 10.05.2019).

63. The Publications Office of the European Union: сайт. -URL: http:// bookshop.europa.eu (дата обращения: 10.05.2019).

64. Бюджетный кодекс Российской Федерации» от 31.07.1998 N 145-Ф3 (ред. от 03.08.2018). КонсультантПлюс: сайт. - URL: http://www.consultant. ru/document/cons_doc_LAW_19702/1b6959f23cc516d0e11ddc2e213ca2dca8 3560df/ (дата обращения: 20.08.2018). 
65. Богачева О.В., Смородинов О.В. «Зеленые облигации как важнейший инструмент финансирования «зелёных» проектов // Финансовый журнал. 2016. № 2. С. 70-81.

66. 10 лет «зеленых» облигаций: формирование модели устойчивых инвестиций для всех рынков капитала / Bсемирный банк: сайт. - URL: http://www.vsemirnyjbank.org/ru/news/immersive-story/2019/03/18/10-yearsof-green-bonds-creating-the-blueprint-for-sustainability-across-capital-markets (дата обращения: 20.08.2018).

67. МГЭИК, 2007: Изменение климата, 2007: Обобщающий доклад. Вклад рабочих групп I, II иІІІ в Четвертый доклад об оценке Межправительственной группы экспертов по изменению климата [Пачаули Р.К., Райзингер А. и основная группа авторов (ред.)]. МГЭИК, Женева, Швейцария, $104 \mathrm{c}$.

68. URL: https://www.icmagroup.org/green-social-and-sustainabilitybonds/green-bond-principles-gbp/

69. На саммите G20 по инициативе Китая впервые обсудят «зеленые финансы» 31.08.2016. CNTV: сайт // http://russian.cctv.com/2016/08/31/ VIDE7XrmxKkui1JtQbWaPcDz160831.shtml (дата обращения: 20.08.2018).

70. Global green bond issuance picked up pace in Q2, and total aligned issuance worldwide reached USD76.9bn for H1 2018. With USD9.3bn worth of green bonds aligned with international green bond definitions, China represents $12 \%$ of the global market over this period. Total issuance from China was USD13bn, but USD3.7bn is not aligned» (Источник: China Green Bond Market Mid-Year Report 2018. - URL: https://www.climatebonds.net/2018/07/ china-green-bond-market-mid-year-report-2018-中国绿色债券市场半年 报-2018 (дата обращения: 15.08.2018).

71. Френч Г. Трава у дома: какое будущее ждет рынок зеленых облигаций. 26.09.2017. Forbs: сайт. - URL: http://www.forbes.ru/ kompanii/350575-trava-u-doma-kakoe-budushchee-zhdet-rynok-zelenyhobligaciy (дата обращения: 10.07.2018).

72. Green bonds global state of the market 2019. - URL: https://www.climatebonds.net/system/tdf/reports/gb_investor_survey-final.pdf?file $=1 \&$ type $=$ node $\& \mathrm{id}=40171 \&$ force $=0$ (дата обращения: 01.10.2020).

73. Climate Bonds Initiative: сайт. - URL: https://www.climatebonds.net/ (дата обращения: 01.10.2020).

74. The European Union: сайт. - URL: Report of the Technical Expert Group (TEG) subgroup on Green Bond Standard. Proposal for an EU Green 
Bond Standard. Interim Report. Document for feedback. Green Bond Standard Subgroup 6 March 2019 (обращения: 20.08.2018).

75. Climate-awareness-bond: сайт. - URL: https://www.climatebonds.net/ green-bond-segments-stock-exchanges. (дата обращения: 05.10.2020).

76. На рынках появились зеленые облигации. Lenta.ru: сайт. - URL: https://lenta.ru/news/2013/12/02/bonds// (дата обращения: 15.07.2018).

77. Зеленые облигации - растет рынок экологических финансовых инструментов. - URL: http://eenergy.media/2017/10/03/zelenye-obligatsii-rastetrynok-ekologicheskih-finansovyh-instrumentov/ (дата обращения: 05.07.2018).

78. Climate Bonds Initiative: сайт. - URL: https://www.climatebonds.net/ (дата обращения: 05.07.2020).

79. The Inquiry: сайт. - URL: unepinquiry.org/countries/ (дата обращения: 03.10.2020).

80. ICMA: сайт. - URL: https://www.icmagroup.org/green-social-andsustainability-bonds/green-bond-principles-gbp/ (дата обращения: 01.07.2018).

81. Проспект компании Apple Ink.: «Рыночная цена облигаций может быть подвержена влиянию любого отказа от использования доходов от облигаций на соответствующие экологические проекты... Несмотря на то что мы согласились с определенными обязательствами по представлению отчетности, как описано в разделе «Использование доходов», невыполнение таких обязательств не будет считаться дефолтом в рамках этого Соглашения». Проспект города Сент-Пол: «Дефолт в соответствии с настоящим Свидетельством о раскрытии не считается дефолтом по облигациям серии 2017C («зеленые облигации») и единственным средством правовой защиты в случае любого нарушения эмитентом требований настоящего Свидетельства о раскрытии информации является обращение в суд». (Цитировано по: Гутборг М., Храплива Ю, Володин С. «Зеленые облигации» как новый финансовый инструмент и перспективы их внедрения в России // Валютное регулирование. Валютный контроль. 2017. № 9. С. 44-52).

82. IPE: сайт. - URL: www.ipe.com (дата обращения: 10.08.2019).

83. Ежемесячный обзор «Устойчивое развитие и зеленые инвестиции». 2019. № 6. С. 12. Национальная ассоциация концессионеров и долгосрочных инвесторов в инфраструктуру ((НАКДИ): сайт. - URL: www. investinfra.ru (дата обращения: 01.08.2019).

84. Церковь Швеции предпочитает инвестировать в зеленые облигации // НАКДИ: сайт: - URL: https://investinfra.ru/biblioteka-lidera/stati/ czerkov-shveczii-predpochitaet-investirovat-v-zeleny'e-obligaczii.html (дата обращения: 01.08.2019). 
85. Зеленые облигации на Московской бирже. Б. Николаев. Независимая газета. 14.01.2019. - URL: http://www.ng.ru/ng_energiya/2019-01-14/ 15_7481_energy 10.html (дата обращения: 01.07.2019).

86. Ежемесячный обзор «Устойчивое развитие и зеленые инвестиции», 2019. - № 5. - 19 с., с.4. Национальная ассоциация концессионеров и долгосрочных инвесторов в инфраструктуру ((НАКДИ): сайт. $-\mathrm{URL}$ : www.investinfra.ru (дата обращения: 01.08.2019).

87. Eligible Debt Instruments // Climate Bonds Initiative: сайт. - URL: https://www.climatebonds.net/certification/types-of-bonds (дата обращения: 01.08.2018).

88. Green bonds the state of the market, 2018. Climate Bonds Initiative: сайт. - URL: https://www.climatebonds.net/ (дата обращения: 01.08.2019).

89. Богачева О.В., Смородинов О.В. Государственный мера по организации и развитию рынка «зеленых» облигаций // Финансовый журнал. 2016. № 3. C. 55-65.

90. Тютюкина Е., Седаш Т. Экологические облигации и депозиты как источник финансирования природоохранных мероприятий // Финансовая жизнь. 2015. № 3. С. 58-62.

91. Седаш Т. Экономические инструменты стимулирования природоохранной деятельности: анализ зарубежного опыта // Финансы и кредит. 2015. № 7. С. 54-63.

92. Каменева Е., Седаш Т. Финансовый инструментарий повышения энергоэффективности экономики России // Менеджмент и бизнес-администрирование. 2015. № 4. С. 93-102.

93. Седаш Т. Переход к «зеленой» экономике в России: миф или реальность? // Финансовая жизнь. 2016. № 1. С. 6-11.

94. Седаш Т. Зарубежный опыт финансирования инфраструктурных и энергосберегающих проектов // Управленческие науки в современном мире. 2017. Т. 1. С. 463-465.

95. Седаш Т. Перспективные инструменты стимулирования «зеленых» инвестиций в России // Управленческие науки в современном мире: сборник докладов научной конференции. Финансовый университет при Правительстве Российской Федерации. СПб.: Изд-во: Издательский дом «Реальная экономика», 2020. - URL: https://www.elibrary.ru/download/ elibrary_43106678_10021645.pdf (дата обращения: 31.10.2020).

96. Седаш Т.Н., Тютюкина Е.Б., Лобанов И.Н. Направления и инструменты финансирования «зеленых» проектов в концепции устойчивого развития экономики // Экономика. Налоги. Право. 2019. №12(5). С. 52-60. 
DOI: 10.26794/1999-849X-2019-12-5-52-60. - URL: https://www.elibrary.ru/ download/elibrary_41331418_41261269.pdf (дата обращения: 01.07.2020).

97. Гутборг М., Храплива Ю, Володин С. «Зеленые облигации» как новый финансовый инструмент и перспективы их внедрения в России // Валютное регулирование. Валютный контроль. 2017. № 9. С. 44-52.

98. Яковлев И.А., Кабир Л.С., Никулина С.И. Климатическая политика Российской Федерации: международное сотрудничество и национальный подход // Финансовый журнал. 2020. Т. 12. № 4. C. 26-36. DOI: 10.31107/2075-1990-2020-4-26-36. - URL: https://www.finjournal-nifi.ru/ru/ archive/34-stati-finansovyj-zhurnal/797-finansovyj-zhurnal-tom-12-4-2020 (дата обращения: 31.10.2020).

99. Формирование финансовой поддержки банками и финансовыми организациями инвестиционных проектов и мероприятий по энергосбережению и повышению энергоэффективности: колл. монография / под ред. И.В. Ларионовой. М.: Изд-во Кнорус, 2017. 120 с.

100. Вержбицкий А. Матрица Теплухина. Бывший партнер «Тройки Диалог» создает бизнес по управлению активами. 09.11.2017 // Forbs: сайт. - URL: http://www.forbes.ru/finansy-i-investicii/351993-matrica-tepluhina-byvshiy-partner-troyki-dialog-sozdaet-biznes-po (дата обращения: 10.08.2018).

101. Экология производства: научно-практический портал: сайт. URL: http://www.ecoindustry.ru/news/company/view/45480.html (дата обращения: 10.08.2018).

102. TACC: сайт. - URL: //http://tass.ru/ekonomika/4823713 (дата обращения: 10.08.2018).

103. Впервые в России были размещены «зеленые» облигации // BCS Express: сайт. - URL: https://bcs-express.ru/novosti-i-analitika/vpervye-vrossii-byli-razmeshcheny-zelenye-obligatsii (дата обращения: 01.08.2019).

104. НАКДИ: сайт. - URL: https://investinfra.ru/novosti/nakdi-otmechaetsamye-vazhnye-sobytiya-v-sfere-konczessij-i-infrastrukturnyx-investiczij2019-goda-.html (дата обращения: 02.01.2020).

105. Правительство России: сайт. - URL: http://government.ru/ info/35569/ (дата обращения: 02.01.2020).

106. Эксперт: сайт. - URL: https://raexpert.ru/docbank/577/9ad/835/ aaf19808c78abfebb8ed28d.pdf (дата обращения: 02.01.2020).

107. Правила предоставления субсидий из Федерального бюджета Российским организациям на возмещение затратна выплату купонного дохода по облигациям, выпущенным в рамках реализации инвестиционных проек- 
тов по внедрению наилучших доступных технологий. Постановление Правительства РФ № 541 от 30.04.2019. Судебные нормативные акты РФ: сайт. URL: https://sudact.ru/law/postanovlenie-pravitelstva-rf-ot-30042019-n-541/ pravila-predostavleniia-subsidii-iz-federalnogo/ (дата обращения: 02.01.2020).

108. Интернет-портал правовой информации: сайт. - URL: http:// publication.pravo.gov.ru/Document/View/0001201905140010 (дата обращения: 02.01.2020).

109. РЖД разместят «зеленые» бонды на 500 млн евро // Интерфакс: сайт. -URL: https://www.interfax.ru/business/661427 16.05.2019 (дата обращения: 02.01.2020).

110. Информационный портал «Будущее России. Национальные проекты»: сайт. - URL: https://futurerussia.gov.ru/nacionalnye-proekty/srocnomedvedev-podpisal-postanovlenie-svazannoe-s-prinatiem-rf-parizskogosoglasenia-po-klimatu (дата обращения: 02.01.2020).

111. Банк «Центр-Инвест»: сайт. - URL: https://www.centrinvest.ru/ru/ about/news/33462/ (дата обращения: 02.01.2020).

112. Совкомбанк: сайт. - URL: https://sovcombank.ru/articles/novostikompanii/sovkombank-predstavil-pervii-rinochnii-zelenii-vipusk-obligatsii-vrossii (дата обращения: 02.01.2020).

113. АО «Коммерческая недвижимость ФПК «Гарант-Инвест»: сайт. URL:https://com-real.ru/files/2019-12/pervie-zelenie-obligacii-aokn. pdf?184f271484 (дата обращения: 02.01.2020).

114. Эксперт: сайт. - URL: https://raexpert.ru/docbank/5f1/4a8/ b0f/3b42bf669a9bbfd305249a6.pdf (дата обращения: 02.01.2020).

115. Компания «Ресурсосбережение XMAO»: сайт. - URL: http://www. rsb-hmao.ru/zelenoe-finansirovanie (дата обращения: 02.01.2020).

116. Интерфакс: сайт. - URL: https://www.interfax.ru/business/661427 16.05.2019 (дата обращения: 02.01.2020).

117. Московская биржа: сайт. - URL: https://www.moex.com/s30194; https://www.moex.com/ru/issue.aspx?board=EQOB\&code=RU000A1011P5 (дата обращения: 02.01.2020).

118. Московская биржа создает Сектор устойчивого развития. при поддержке Минэкономразвития РФ. 05.08.2019. Московская биржа: сайт. URL: https://www.moex.com/n24553/?nt=106 (дата обращения: 05.01.2020).

119. Сектор роста: Московская биржа: сайт. - URL: https://www.moex. com/s2151 (дата обращения: 05.01.2020).

120. РИИ Московской биржи. Московская биржа: сайт. - URL: https:// www.moex.com/s25 (дата обращения: 05.01.2020). 
121. Кабмин утвердил правила субсидирования «зеленых облигаций»05.05.2019. ТАCC: сайт. - URL: https://tass.ru/nacionalnyeproekty/6404985 (дата обращения: 10.01.2020).

\section{Глава 3}

122. Паспорт национального проекта «Экология» (утв. президиумом Совета при Президенте РФ по стратегическому развитию и национальным проектам, протокол от 24.12.2018 N 16). КонсультантПлюс: сайт. URL: http://www.consultant.ru/cons/cgi/online.cgi?req=doc\&ts $=12208359550$ 03344427124358296\& cacheid=AFC6667B28E7FDC27A446AF5513A3327\& mode $=$ splus $\&$ base $=$ LAW $\& n=316096 \& \mathrm{rnd}=\mathrm{C} 8 \mathrm{~A} 6 \mathrm{~B} 3 \mathrm{C} 3 \mathrm{CFCE} 0 \mathrm{FCCFA} 04167 \mathrm{~A}$ 26975C74\#1 mmoc3xpgvv (дата обращения: 10.01.2020).

123. Распоряжение Правительства РФ от 17.11.2008 N 1662-р (ред. от 28.09.2018) «О Концепции долгосрочного социально-экономического развития Российской Федерации на период до 2020 года» (вместе с «Концепцией долгосрочного социально-экономического развития Российской Федерации на период до 2020 года»). - КонсультантПлюс: сайт. - URL: http://www.consultant.ru/cons/cgi/online.cgi?req=doc\&ts=1220835955003344 427124358296\&cacheid=B20E94C8832B8402951F60A94A1A2368\&mode $=$ splus \&base $=$ LAW $\& n=308069 \&$ rnd $=$ C 8 A6B3C3CFCE0FCCFA04167A26975 C74\#1qejt0uidy8 (дата обращения: 06.01.2020).

124. Распоряжение Президента РФ от 17.12.2009 N 861-рп «О Климатической доктрине Российской Федерации»»». - КонсультантПлюс: сайт. URL: http://www.consultant.ru/cons/cgi/online.cgi?req=doc\&ts $=12208359550$ 03344427124358296\&cacheid=6B91E537B900AE71DE5B675F3CDAFD4B $\&$ mode $=$ splus \&base $=$ LAW $\& n=94992 \&$ rnd $=$ C 8 A6B3C3CFCE0FCCFA04167 A26975C74\#1vhocg7hfzs обращения: 06.01.2020).

125. Указ Президента РФ от 13.05.2017 N 208 «О Стратегии экономической безопасности Российской Федерации на период до 2030 года». КонсультантПлюс: сайт. - URL: http://www.consultant.ru/cons/cgi/online.cgi?req= doc $\&$ ts $=1220835955003344427124358296 \&$ cacheid $=54416$ A6F $832 B 336509 \mathrm{~A}$ $343661 \mathrm{E} 32021 \mathrm{~F} \&$ mode $=$ splus $\&$ base $=$ LAW $\& n=216629 \& \mathrm{rnd}=\mathrm{C} 8 \mathrm{~A} 6 \mathrm{~B} 3 \mathrm{C} 3 \mathrm{CFCE}$ 0FCCFA04167A26975C74\#18j0qth36уо (дата обращения: 06.01.2020).

126. Основы государственной политики в области экологического развития Российской Федерации на период до 2030 года (утв. Президентом РФ 30.04.2012). - КонсультантПлюс: сайт. - URL: http://www.consultant.ru/ cons/cgi/online.cgi? req $=$ doc \&ts $=1220835955003344427124358296 \&$ cacheid $=$ B20E94C8832B8402951F60A94A1A2368\&mode=splus\&base $=$ LAW \&n=129 
117\& rnd=C8A6B3C3CFCE0FCCFA04167A26975C74\#2iasjcspx20 (дата обращения: 08.01.2020).

127. Распоряжение Правительства РФ от 18.12.2012 N 2423-р (ред. от 10.08.2016) «Об утверждении Плана действий по реализации Основ государственной политики в области экологического развития Российской Федерации на период до 2030 года». КонсультантПлюс: сайт. - URL: http://www.consultant.ru/cons/cgi/online.cgi?req=doc\&ts=1220835955003344 427124358296\&cacheid=E71D71B9C9A28B9DBF6E80002EA18599\&mode $=$ splus $\&$ base $=$ LAW $\& n=203295 \& \mathrm{rnd}=\mathrm{C} 8 \mathrm{~A} 6 \mathrm{~B} 3 \mathrm{C} 3 \mathrm{CFCE0FCCFA04167A2697}$ 5C74\#8nyjvqc3oe (дата обращения: 08.01.2020).

128. Постановление Правительства РФ от 03.01.2014 N 3 (ред. от 01.08.2019) «Об утверждении Правил предоставления субсидий из федерального бюджета российским организациям на возмещение части затрат на уплату процентов по кредитам, полученным в 2014 - 2019 годах в российских кредитных организациях и государственной корпорации «Банк развития и внешнеэкономической деятельности (Внешэкономбанк)», а также в международных финансовых организациях, созданных в соответствии с международными договорами, в которых участвует Российская Федерация, на реализацию комплексных инвестиционных проектов по приоритетным направлениям гражданской промышленности и (или) выплату купонного дохода по облигациям, выпущенным в 2014 2019 годах в рамках реализации комплексных инвестиционных проектов по приоритетным направлениям гражданской промышленности». КонсультантПлюс: сайт. - URL: http://www.consultant.ru/cons/cgi/online.cgi?req=doc $\&$ ts $=31209415008796086833809127 \&$ cacheid $=52 \mathrm{DA} 85 \mathrm{E} 862 \mathrm{BB} 3850 \mathrm{E} 40 \mathrm{E} 6 \mathrm{~A}$ 0EE71C538E $\&$ mode $=$ splus \&base $=$ LAW $\& n=330779 \& \mathrm{rnd}=20 \mathrm{~B} 7 \mathrm{~F} 4 \mathrm{BEA} 5995 \mathrm{E}$ 94C8B0EC9E786E47BD\#1d2gqdwyr8t (дата обращения: 08.01.2020).

129. Постановление Правительства РФ от 20.07.2016 N 702 «О применении базовых индикаторов при расчете параметров субсидирования процентной ставки за счет средств федерального бюджета по кредитам, облигационным займам и (или) договорам лизинга в зависимости от сроков кредитования, а также определении предельного уровня конечной ставки кредитования, при превышении которого субсидирование процентной ставки не осуществляется». КонсультантПлюс: сайт. - URL: http:// www.consultant.ru/cons/cgi/online.cgi?rnd=20B7F4BEA5995E94C8B0EC9E 786E47BD\&req $=$ doc $\&$ base $=$ LAW $\& n=202197 \&$ REFFIELD $=134 \&$ REFDST $=$ $62 \&$ REFDOC $=330779 \&$ REFBASE $=$ LAW \&stat $=$ refcode $\% 3 \mathrm{D} 16876 \% 3$ Binde X\%3D109\#1j3rpipiehm (дата обращения: 08.01.2020). 
130. Постановление Правительства РФ от 17.07.2015 N 719 (ред. от 21.12.2019) «О подтверждении производства промышленной продукции на территории Российской Федерации» (с изм. и доп., вступ. в силу с 01.01.2020) КонсультантПлюс: сайт. - URL: http://www.consultant.ru/ cons/cgi/online.cgi?req $=$ doc\&ts $=1220835955003344427124358296 \&$ cacheid $=$ 60EB2274EDC4EAAC7AD7251C85A2671C\&mode $=$ splus\&base $=$ LAW\&n= $335914 \& \mathrm{rnd}=\mathrm{C} 8 \mathrm{~A} 6 \mathrm{~B} 3 \mathrm{C} 3 \mathrm{CFCE} 0 \mathrm{FCCFA04167A26975C74 \# 12 \textrm {f } 1 \mathrm { xkzg } 6 7 5}$ (дата обращения: 11.01.2020).

131. Проект Федерального закона «О внесении изменений части первую и вторую Налогового кодекса Российской Федерации» (подготовлен Минфином России). КонсультантПлюс: сайт. - URL: http://www.consultant. $\mathrm{ru} /$ cons/cgi/online.cgi?req $=$ doc; base $=$ PRJ $; n=174477 \# 007884157310985018$ (дата обращения: 11.01.2020).

132. Бобошко Н.М. Экологический налог в системе обеспечения экологической безопасности // Вопросы региональной экономики. 2018. № 4 (37). С. 121-126.

133. Филичева Т.П., Горкина И.Д. О переводе природоохранных платежей в статус экологического налога // Территория новых возможностей. Вестник Владивостоксого государственного университета экономики и сервиса. 2018. Т. 10. № 4. С. 49-57.

134. Аникин А.А. Эколого-экономическое развитие регионов: совершенствование методологии и методики оценки / И.Д. Аникина, А.А. Аникин. Волгоград: изд-во ВолГУ, 2019. 196 с.

135. Anikina I.D., Anikin A.A. (2020) Environmental and Economic Security as the Condition of the Regions' Competitiveness. In: Inshakova A., Inshakova E. (eds) Competitive Russia: Foresight Model of Economic and Legal Development in the Digital Age. CRFMELD 2019. Lecture Notes in Networks and Systems, vol 110. Springer, Cham. https://doi.org/10.1007/978-3-030-45913-0_23.

136. Эксперт: сайт. - URL: https://raexpert.ru/ratings/corporatebond/ ratingscale/ (дата обращения: 05.05. 2019).

137. Бобылев, С.Н., Минаков В.С. и др. Эколого-экономический индекс регионов РФ. Методика и показатели для расчета. M.: WWF России, РИА Новости, 2012. 152 с.

138. Рождественская, Я. Человечество поставило под угрозу миллион других видов. Коммерсантъ, 06.may.2019.

139. Единая межведомственная информационно-статистическая база // https://fedstat.ru/, сайты ТОГС // http://www.gks.ru/wps/wcm/connect/ rosstat_main/rosstat/ru/about/territorial/site/. 


\section{ПРИЛОЖЕНИЯ}

Приложение А

Термины и определения на рынке зеленого финансирования

\begin{tabular}{|c|c|}
\hline Термин & Определение \\
\hline $\begin{array}{l}\text { Верификация } \\
\text { (подтверждение } \\
\text { соответствия) }\end{array}$ & $\begin{array}{l}\text { - процедура оценки документов заявителя установленным } \\
\text { требованиям. В международной практике осуществляется не- } \\
\text { зависимыми консультантами (second party opinion) с под- } \\
\text { твержденной репутацией на рынке. }\end{array}$ \\
\hline $\begin{array}{l}\text { Зеленые } \\
\text { инвестиции }\end{array}$ & $\begin{array}{l}\text { - вложения в экологически чистые и ресурсосберегающие } \\
\text { технологии. Обычно подразумевают инвестиции в различные } \\
\text { программы и проекты, целью которых является развитие зе- } \\
\text { леной экономики. }\end{array}$ \\
\hline $\begin{array}{l}\text { Зеленые } \\
\text { кредиты }\end{array}$ & $\begin{array}{l}\text { - займы, которые были предоставлены и пошли на реализа- } \\
\text { цию зеленых проектов, а также на улучшение экологии. }\end{array}$ \\
\hline $\begin{array}{l}\text { Зеленые } \\
\text { облигации }\end{array}$ & $\begin{array}{l}\text { - особый вид облигаций, выпускаемых с целью обеспечения } \\
\text { зеленого финансирования, т.е. реализации программ и про- } \\
\text { ектов, направленных на развитие зеленой экономики. }\end{array}$ \\
\hline $\begin{array}{l}\text { Зеленые } \\
\text { проекты }\end{array}$ & $\begin{array}{l}\text { - проекты, реализуемые в рамках зеленой экономики. Обычно } \\
\text { речь идет о проектах, направленных на обеспечение сохран- } \\
\text { ности окружающей среды, создание инфраструктуры, снижа- } \\
\text { ющей негативное воздействие изменения климата и т.п. }\end{array}$ \\
\hline $\begin{array}{l}\text { Зеленое } \\
\text { страхование }\end{array}$ & $\begin{array}{l}\text { - страхование ответственности за загрязнение окружающей } \\
\text { среды. }\end{array}$ \\
\hline $\begin{array}{l}\text { Зеленые } \\
\text { технологии }\end{array}$ & $\begin{array}{l}\text { - это инновационные технологии, в основе которых лежат } \\
\text { принципы устойчивого развития и повторное использование } \\
\text { или экономия природных ресурсов. }\end{array}$ \\
\hline $\begin{array}{l}\text { Зеленые } \\
\text { финансы }\end{array}$ & $\begin{array}{l}\text { - финансовые услуги, предназначенные для поддержки эко- } \\
\text { номической деятельности, которая направлена на улучшение } \\
\text { окружающей среды, смягчение последствий изменения } \\
\text { глобального климата и более эффективное использование } \\
\text { ресурсов. }\end{array}$ \\
\hline $\begin{array}{l}\text { Зеленые } \\
\text { финансовые } \\
\text { инструменты }\end{array}$ & $\begin{array}{l}\text { - классические финансовые инструменты, посредством кото- } \\
\text { рых финансируются исключительно зеленые проекты. Ис- } \\
\text { пользование данного типа финансовых инструментов требу- } \\
\text { ет более детального раскрытия информации для широкого } \\
\text { круга лиц. }\end{array}$ \\
\hline
\end{tabular}


Окончание приложения А

\begin{tabular}{|c|c|}
\hline $\begin{array}{l}\text { Наилучшая } \\
\text { доступная } \\
\text { технология } \\
\text { (НДТ) }\end{array}$ & $\begin{array}{l}\text { - технология производства продукции (товаров), выполнения } \\
\text { работ, оказания услуг, определяемая на основе современных } \\
\text { достижений науки и техники и наилучшего сочетания крите- } \\
\text { риев достижения целей охраны окружающей среды при усло- } \\
\text { вии наличия технической возможности ее применения. }\end{array}$ \\
\hline $\begin{array}{l}\text { Ответственное } \\
\text { инвестирование }\end{array}$ & $\begin{array}{l}\text { - инвестирование, целями которого является не только полу- } \\
\text { чение дохода инвестором, но и создание позитивных социаль- } \\
\text { ных изменений, снижение негативного воздействия на при- } \\
\text { родную среду, соответствие этическим нормам. }\end{array}$ \\
\hline $\begin{array}{l}\text { Проектные } \\
\text { зеленые } \\
\text { облигации }\end{array}$ & $\begin{array}{l}\text { - долговое обязательство, согласно которому инвестор несет } \\
\text { прямой кредитный риск, связанный с финансированием про- } \\
\text { екта или нескольких проектов. Инструмент может предусма- } \\
\text { тривать или не предусматривать право регресса к эмитенту. }\end{array}$ \\
\hline $\begin{array}{l}\text { Секьюритизиро- } \\
\text { ванные зеленые } \\
\text { облигации }\end{array}$ & $\begin{array}{l}\text { - долговое обязательство, обеспеченное одним или несколь- } \\
\text { кими конкретными проектами или активами, включая ипотеч- } \\
\text { ные, и обеспеченные активами ценные бумаги. Первоначаль- } \\
\text { ным источником выплат по облигациям такого вида является, } \\
\text { как правило, денежный поток, генерируемый активами, леж-- } \\
\text { щими в основе выпуска. }\end{array}$ \\
\hline $\begin{array}{l}\text { Устс } \\
\text { разв }\end{array}$ & $\begin{array}{l}\text { - сформулированная ООН концепция управления социально- } \\
\text { экономическим развитием человечества для сохранения био- } \\
\text { сферы и выживания человека, предлагаемая правительствам } \\
\text { всех стран для руководства к действию при разработке пла- } \\
\text { нов и решений в сфере государственного управления. }\end{array}$ \\
\hline $\begin{array}{l}\text { Фина } \\
\text { инстр }\end{array}$ & $\begin{array}{l}\text { - договор, при заключении которого одновременно возникают } \\
\text { финансовый актив у первой организации, а у второй органи- } \\
\text { зации - долевой инструмент или финансовое обязательство. }\end{array}$ \\
\hline $\begin{array}{l}\text { Экологический } \\
\text { риск }\end{array}$ & $\begin{array}{l}\text { - вероятность появления отрицательных изменений в окружа- } \\
\text { ющей природной среде, вызванных антропогенным или иным } \\
\text { воздействием. }\end{array}$ \\
\hline $\begin{array}{l}\text { Экологическое } \\
\text { страхование }\end{array}$ & $\begin{array}{l}\text { - совокупность различных видов страхования экологических } \\
\text { рисков, направленных на создание страховой защиты на слу- } \\
\text { чай причинения страхователям ущерба в результате реализа- } \\
\text { ции экологических рисков. }\end{array}$ \\
\hline
\end{tabular}

Источник: Зеленые финансы: повестка дня для России: диагностическая записка. Экспертный совет по рынку долгосрочных инвестиций при Банке России. M., октябрь 2018. C. 12-13. - URL: https://m.minfin.ru/common/upload/20181102 Green_finance.pdf (дата обращения: 05.01.2020). 
Приложение Б

Т аблиц а Б . 1

Обзор рыночных долговых инструментов «зеленого» финансирования

(Eligible Debt Instruments, which can be Certified under the Climate Bonds Standard V2.1)

\begin{tabular}{|c|c|c|}
\hline $\begin{array}{c}\text { Debt } \\
\text { Instruments }\end{array}$ & Definition & Examples \& Comments \\
\hline $\begin{array}{l}\text { Use of Proceeds } \\
\text { Bond }\end{array}$ & $\begin{array}{l}\text { A standard recourse-to-the-issuer debt } \\
\text { obligation for which the proceeds shall } \\
\text { be credited to a sub-account, moved to a } \\
\text { sub-portfolio or otherwise tracked by the } \\
\text { issuer and attested to by a formal inter- } \\
\text { nal process that will be linked to the is- } \\
\text { suer's lending and investment operations } \\
\text { for Eligible Projects \& Assets. }\end{array}$ & $\begin{array}{l}\text { Certified Climate Bonds: } \\
\text { NAB, ANZ, ABN } \\
\text { AMRO, Axis Bank, } \\
\text { Westpac, Deutsche } \\
\text { Kredit Bank, Treasury } \\
\text { Corporation Victoria, } \\
\text { NTPC }\end{array}$ \\
\hline $\begin{array}{l}\text { Use of Proceeds } \\
\text { Revenue Bond }\end{array}$ & $\begin{array}{l}\text { A non-recourse debt obligation in which } \\
\text { the credit exposure in the bond is to the } \\
\text { pledged cash flows of the revenue } \\
\text { streams, fees, taxes etc., and the use of } \\
\text { proceeds of the bond goes to related or } \\
\text { unrelated Eligible Projects \& Assets. }\end{array}$ & $\begin{array}{l}\text { Certified Climate Bonds: } \\
\text { New York MTA, San } \\
\text { Francisco PUC, }\end{array}$ \\
\hline Project Bond & $\begin{array}{l}\text { A project bond for a single or multiple } \\
\text { Eligible Projects \& Assets for which the } \\
\text { investor has direct exposure to the risk } \\
\text { of the project(s) with or without poten- } \\
\text { tial recourse to the issuer. }\end{array}$ & $\begin{array}{l}\text { Certified Climate Bonds: } \\
\text { AP Renewables, Inc } \\
\text { (with ADB), ReNew } \\
\text { Power }\end{array}$ \\
\hline \multirow[t]{2}{*}{$\begin{array}{l}\text { Covered Bond or } \\
\text { Pfandbrief }\end{array}$} & $\begin{array}{l}\text { A dual recourse bond which relies pri- } \\
\text { marily on repayment from the issuer, but } \\
\text { also has access to a pool of assets (the } \\
\text { cover pool). } \\
\text { The cover pool often comprises mort- } \\
\text { gages, but Other assets can be used as } \\
\text { collateral too. For instance the German } \\
\text { Pfandbrief market includes Mortgage } \\
\text { Pfandbrief, Public Pfandbrief, Ship and } \\
\text { Aircraft Pfandfbrief. }\end{array}$ & \\
\hline & $\begin{array}{l}\text { Luxembourg has proposed a law on } \\
\text { renewable infrastructure covered bonds. }\end{array}$ & \\
\hline
\end{tabular}


Продолжение приложения Б

\begin{tabular}{|c|c|c|}
\hline $\begin{array}{c}\text { Debt } \\
\text { Instruments }\end{array}$ & Definition & Examples \& Comments \\
\hline $\begin{array}{l}\text { Securitisation } \\
\text { (ABS) Bond }\end{array}$ & $\begin{array}{l}\text { A bond collateralized by one or more } \\
\text { specific Eligible Projects \& Assets, in- } \\
\text { cluding Asset Backed Securities } \\
\text { ("ABS"), Mortgage Backed Securities } \\
\text { ("MBS"), and other securitisation struc- } \\
\text { tures. The only source of repayment is } \\
\text { the cash flows of the assets. }\end{array}$ & $\begin{array}{l}\text { Certified Climate Bonds } \\
\text { Flexigroup, Obvion }\end{array}$ \\
\hline $\begin{array}{l}\text { Convertible } \\
\text { Bond or Notes }\end{array}$ & $\begin{array}{l}\text { Bonds or notes which have the right but } \\
\text { not the obligation to convert into a spec- } \\
\text { ified number of ordinary shares (or other } \\
\text { securities) under specified terms and } \\
\text { conditions. }\end{array}$ & $\begin{array}{l}\text { If the bond was Certified } \\
\text { at issue but later convert- } \\
\text { ed to equity, then its sta- } \\
\text { tus as a Certified Cli- } \\
\text { mate Bond would end at } \\
\text { the point of conversion. }\end{array}$ \\
\hline $\begin{array}{l}\text { Commercial } \\
\text { Paper }\end{array}$ & $\begin{array}{l}\text { Short-term debt securities. Unsecured } \\
\text { promissory notes issued by strong cred- } \\
\text { its including both financial institutions } \\
\text { and non-bank corporates, generally with } \\
\text { maturity of } 270 \text { days or less. 'Short- } \\
\text { term' in this context means that it has a } \\
\text { term of less than } 365 \text { days where issued } \\
\text { in the UK. Different rules apply in the } \\
\text { US market. }\end{array}$ & $\begin{array}{l}\text { Certified Climate Bonds: } \\
\text { Contact Energy }\end{array}$ \\
\hline $\begin{array}{l}\text { Commercial } \\
\text { Paper }\end{array}$ & $\begin{array}{l}\text { Short-term debt securities. Unsecured } \\
\text { promissory notes issued by strong credits } \\
\text { including both financial institutions and } \\
\text { non-bank corporates, generally with matu- } \\
\text { rity of } 270 \text { days or less. 'Short-term' in this } \\
\text { context means that it has a term of less } \\
\text { than } 365 \text { days where issued in the UK. } \\
\text { Different rules apply in the US market. }\end{array}$ & $\begin{array}{l}\text { Certified Climate Bonds: } \\
\text { Contact Energy }\end{array}$ \\
\hline Sukuk & $\begin{array}{l}\text { "Sukuk" is a term referring to various } \\
\text { types of quasi-debt securities that have } \\
\text { been developed to meet the strictures of } \\
\text { Islamic finance. One of the core princi- } \\
\text { pals underlying Islamic finance is avoid- } \\
\text { ing the payment or collecting of interest. } \\
\text { A variety of financial instruments have } \\
\text { been created that serve the same purpose } \\
\text { as bonds and other debt securities, but } \\
\text { on which interest technically is not paid. }\end{array}$ & \\
\hline
\end{tabular}


Продолжение приложения Б

\begin{tabular}{|c|c|c|}
\hline $\begin{array}{c}\text { Debt } \\
\text { Instruments }\end{array}$ & Definition & Examples \& Comments \\
\hline Loan Facility & $\begin{array}{l}\text { A credit line made available to borrow- } \\
\text { ers to finance projects or for other pur- } \\
\text { poses. Loans can be secured and unse- } \\
\text { cured. Typical examples of secured } \\
\text { loans are project finance } \\
\text { facilities and mortgages. } \\
\text { Loan types include bilateral facilities be- } \\
\text { tween a borrower or borrower group and } \\
\text { single lender); syndicated facilities be- } \\
\text { tween a borrower/borrower group and a } \\
\text { club or syndicate of lenders, which may } \\
\text { include non-bank lenders such a insur- } \\
\text { ance companies, debt funds, hedge funds } \\
\text { and private equity investors; structured } \\
\text { finance, which includes loan tranches } \\
\text { with different risk and pricing charac- } \\
\text { trestics; facilities designed for a specific } \\
\text { function such as export credit facility, } \\
\text { credit line, etc. } \\
\text { A loan facility can use a set of screens or } \\
\text { criteria to identify which underlying as- } \\
\text { sets can be financed via the facility. } \\
\text { Screens could include underlying assets } \\
\text { must meet the sector-specific criteria of } \\
\text { the Climate Bonds Standard. } \\
\text { The Loan Market Association published } \\
\text { the Green Loan Principles in March } \\
2018 \text { which provide similar guidance for } \\
\text { green loans as the ICMA Green Bond } \\
\text { Principles provide for green bonds. }\end{array}$ & $\begin{array}{l}\text { Loans Certified under } \\
\text { the Climate Bonds Stan- } \\
\text { dard: MEP Werke, } \\
\text { Quadran, Energies Li- } \\
\text { bres, Ivanhoe Cam- } \\
\text { bridge and Natixis As- } \\
\text { surances (DUO), OVG }\end{array}$ \\
\hline
\end{tabular}

Источник: Eligible Debt Instruments // Climate Bonds Initiative: сайт. - URL: https://www.climatebonds.net/certification/types-of-bonds (дата обращения: 01.06.2019). 
Продолжение приложения Б

Т а блиц ц Б . 2

\section{Глоссарий инструментов «зеленого» финансирования}

\begin{tabular}{|c|c|c|}
\hline Термины & Определение (англ.) & Определение (русск.) \\
\hline Green Bond & $\begin{array}{l}\text { A financial debt instrument } \\
\text { that is linked with green } \\
\text { and climate friendly assets } \\
\text { or projects. }\end{array}$ & $\begin{array}{l}\text { Финансовый долговой инстру- } \\
\text { мент, который связан с зелеными } \\
\text { и климатически дружелюбными } \\
\text { активами или проектами. }\end{array}$ \\
\hline $\begin{array}{l}\text { Climate Bonds } \\
\text { Standard \& } \\
\text { Certification }\end{array}$ & $\begin{array}{l}\text { Climate Bonds Initiative's } \\
\text { "FairTrade"-like scheme } \\
\text { that ensures the bond is } \\
\text { aligned with the Paris } \\
\text { Agreement-2 degree warm- } \\
\text { ing limit. This scheme is } \\
\text { comprised of several steps } \\
\text { and processes. }\end{array}$ & $\begin{array}{l}\text { Инициативы, связанные с клима- } \\
\text { тическими облигациями по прин- } \\
\text { ципу “Честной торговли”, кото- } \\
\text { рые удостоверяют, что облигация } \\
\text { соответствует Парижскому со- } \\
\text { глашению 2-ой степени о пределе } \\
\text { потепления. Эта схема состоит } \\
\text { из нескольких шагов и процессов. }\end{array}$ \\
\hline Issuer & $\begin{array}{l}\text { The entity that wants to issue } \\
\text { a green bond and highlight } \\
\text { its green and climate friendly } \\
\text { credentials. This can be a pri- } \\
\text { vate company, a listed com- } \\
\text { pany, a bank, a government } \\
\text { department, a government } \\
\text { related agency, etc. }\end{array}$ & $\begin{array}{l}\text { Субъект, который хочет выпустить } \\
\text { зеленые облигации, при этом под- } \\
\text { черкивая их зеленый статус и со- } \\
\text { ответствие стандартам климати- } \\
\text { чески дружелюбной деятельности. } \\
\text { Это может быть частная компания, } \\
\text { котирующаяся компания, банк, де- } \\
\text { партамент правительства и соот- } \\
\text { ветствующие ведомства, и т.д. }\end{array}$ \\
\hline Verifier & $\begin{array}{l}\text { A third party, independent } \\
\text { company that checks the } \\
\text { bond against the Climate } \\
\text { Bonds Standard and provide } \\
\text { assurance to the market that } \\
\text { the bond meets the require- } \\
\text { ments. }\end{array}$ & $\begin{array}{l}\text { Третья сторона, независимая } \\
\text { компания, которая проверяет } \\
\text { облигацию согласно Стандар- } \\
\text { ту Климатических Облигаций } \\
\text { и обеспечивает для рынка гаран- } \\
\text { тии того, что облигация соответ- } \\
\text { ствует всем требованиям. } \\
\end{array}$ \\
\hline Verification & $\begin{array}{l}\text { The process by which the } \\
\text { bond issuer engages a Ver- } \\
\text { ifier to ensure their bond } \\
\text { issuance complies with the } \\
\text { Climate Bonds Standard } \\
\text { and Certification Scheme. } \\
\text { It is comprised of steps both } \\
\text { before and after the bond is- } \\
\text { suance (see below). }\end{array}$ & $\begin{array}{l}\text { Верификация - это процесс, } \\
\text { по которому проверяющая } \\
\text { компания проводит проверки } \\
\text { в отношении эмитента облига- } \\
\text { ций для обеспечения соответ- } \\
\text { ствия выпускаемых облигаций } \\
\text { стандарту Климатических Обли- } \\
\text { гаций и схеме сертификации. Он } \\
\text { состоит из шагов, имеющих ме- } \\
\text { сто как до, так и после выпуска } \\
\text { облигаций (см. ниже). }\end{array}$ \\
\hline
\end{tabular}


Продолжение приложения Б

\begin{tabular}{|c|c|c|}
\hline Термины & Определение (англ.) & Определение (русск.) \\
\hline $\begin{array}{l}\text { Pre-issuance } \\
\text { verification }\end{array}$ & $\begin{array}{l}\text { The «first half» of the veri- } \\
\text { fication process, which hap- } \\
\text { pens before the bond the is- } \\
\text { suance. This may take from } \\
\text { a couple of weeks up to a } \\
\text { few months, depending on } \\
\text { the complexity of the bond } \\
\text { or assets. The issuer engag- } \\
\text { es an Approved Verifier, } \\
\text { who will guide the issuer } \\
\text { through the process of Cer- } \\
\text { tification and if necessary, } \\
\text { help them identify which } \\
\text { projects and assets are eli- } \\
\text { gible. The Verifier will then } \\
\text { complete a report for the } \\
\text { Climate Bonds Standard } \\
\text { Board to review and under- } \\
\text { stand whether the bond is } \\
\text { eligible for Certification. }\end{array}$ & $\begin{array}{l}\text { Первая половина процесса ве- } \\
\text { рификации, которая происходит } \\
\text { до выпуска облигаций. Эта ста- } \\
\text { дия может занять от нескольких } \\
\text { недель до нескольких месяцев, } \\
\text { в зависимости от сложности об- } \\
\text { лигации или активов. Одобрен- } \\
\text { ная сторона, проводящая вери- } \\
\text { фикацию, направляет эмитента } \\
\text { через процесс сертификации и, } \\
\text { в случае необходимости, помо- } \\
\text { гает определить, какие проекты } \\
\text { и активы подходят. Затем прове-- } \\
\text { ряющий готовит отчет для Сове- } \\
\text { та по Стандартам Климатических } \\
\text { Облигаций, который в дальней- }- \\
\text { шем рассматривает и принимает } \\
\text { решение, имеет ли облигация } \\
\text { право на сертификацию. }\end{array}$ \\
\hline $\begin{array}{l}\text { Pre-issuance } \\
\text { Verification report }\end{array}$ & $\begin{array}{l}\text { The report produced as a } \\
\text { part of the pre issuance ver- } \\
\text { ification procedures. }\end{array}$ & $\begin{array}{l}\text { Отчет, подготовленный в рамках } \\
\text { процедур верификации до выпу- } \\
\text { ска облигаций. }\end{array}$ \\
\hline $\begin{array}{l}\text { Post-issuance } \\
\text { verification }\end{array}$ & $\begin{array}{l}\text { The «second half» of the } \\
\text { verification process, which } \\
\text { happens after the bond is- } \\
\text { suance. This is simpler and } \\
\text { generally a quick check to } \\
\text { see that the issuer has fol- } \\
\text { lowed its plans and allocat- } \\
\text { ed the funds appropriately } \\
\text { as stated in the pre issuance } \\
\text { verification. The issuer en- } \\
\text { gages the same Verifier as } \\
\text { before and a report is pro- } \\
\text { duced within } 12 \text { months of } \\
\text { the bond issuance. }\end{array}$ & $\begin{array}{l}\text { «Вторая половина» процесса ве- } \\
\text { рификации, который происходи } \\
\text { после выпуска облигаций. Это } \\
\text { более простая и обычно быстрая } \\
\text { проверка того, что эмитент сле- } \\
\text { дует своим планам и разместил } \\
\text { средства надлежащим образом, } \\
\text { как это было указано при вери- } \\
\text { фикации до выпуска облигаций. } \\
\text { Эмитент сталкивается с тем же } \\
\text { проверяющим, что был раньше, } \\
\text { и доклад подготавливается в те- } \\
\text { чение } 12 \text { месяцев с момента вы- } \\
\text { пуска облигаций. } \\
\end{array}$ \\
\hline $\begin{array}{l}\text { Post-issuance } \\
\text { Verification report }\end{array}$ & $\begin{array}{l}\text { The report produced as a } \\
\text { part of the post issuance } \\
\text { verification procedures }\end{array}$ & $\begin{array}{l}\text { Отчет, подготовленный в рамках } \\
\text { процедур верификаци п после } \\
\text { выпуска облигаций. }\end{array}$ \\
\hline
\end{tabular}


Окончание приложения Б

\begin{tabular}{|c|c|c|}
\hline Термины & Определение (англ.) & Определение (русск.) \\
\hline Annual Reporting & $\begin{array}{l}\text { Over the term of the bond, } \\
\text { the issuer will provide a } \\
\text { report to confirm that their } \\
\text { assets haven't changed and } \\
\text { the funds are allocated ap- } \\
\text { propriately. This report will } \\
\text { be published on Climate } \\
\text { Bonds' website and public- } \\
\text { ly available. Climate Bonds' } \\
\text { does not require that this re- } \\
\text { port have any involvement } \\
\text { of the Verifier, however } \\
\text { some issuers have chosen } \\
\text { to engage the Verifier again } \\
\text { to produce more detailed } \\
\text { reports. }\end{array}$ & $\begin{array}{l}\text { В течение срока выпуска облига- } \\
\text { ций эмитент представит доклад } \\
\text { для подтверждения, что их акти- } \\
\text { вы не были изменены, средства } \\
\text { распределяются надлежащим } \\
\text { образом. Этот доклад будет опу- } \\
\text { бликован на веб-сайте климати- } \\
\text { ческих облигаций в открытом } \\
\text { доступе. Климатические обли- } \\
\text { гации не требуют какого-либо } \\
\text { участия проверяющей компании } \\
\text { при составлении данного докла- } \\
\text { да, однако некоторые эмитенты } \\
\text { решают привлечь проверяюще- } \\
\text { го снова для составления более } \\
\text { подробных докладов. }\end{array}$ \\
\hline
\end{tabular}

Источник: Glossary // Climate Bonds Initiative: сайт. - URL: https://www.climatebonds.net/certification/glossary (дата обращения: 01.06.2019) (перевод - Аникин А.А.) 
Приложение в

Эмитенты сектора Роста Московской биржи

\begin{tabular}{|c|c|c|c|}
\hline Эмитент/Фонд & Отрасль/сектор & $\begin{array}{c}\text { Тип } \\
\text { инстру- } \\
\text { мента }\end{array}$ & $\begin{array}{l}\text { Субъект } \\
\text { МСП }\end{array}$ \\
\hline $\begin{array}{l}\text { ООО «Обувь } \\
\text { России» }\end{array}$ & $\begin{array}{l}\text { Розничная и оптовая торговля обу- } \\
\text { вью и сопутствующими товарами }\end{array}$ & $\begin{array}{l}\text { Биржевые } \\
\text { облигации }\end{array}$ & - \\
\hline АО «Полипласт» & $\begin{array}{l}\text { Производство химических добавок } \\
\text { для различных отраслей промыш- } \\
\text { ленности }\end{array}$ & $\begin{array}{l}\text { Биржевые } \\
\text { облигации }\end{array}$ & + \\
\hline ПАО «ГТМ» & Грузовые перевозки & Акция & - \\
\hline ПАО «OР» & $\begin{array}{l}\text { Розничная и оптовая торговля обу- } \\
\text { вью и сопутствующими товарами }\end{array}$ & Акция & - \\
\hline АО «ИнфоВотч» & $\begin{array}{l}\text { Информационная безопасность } \\
\text { в корпоративном секторе }\end{array}$ & $\begin{array}{l}\text { Биржевые } \\
\text { облигации }\end{array}$ & + \\
\hline $\begin{array}{l}\text { АО «Светофор } \\
\text { Групп» }\end{array}$ & $\begin{array}{l}\text { Оператор образовательных услуг } \\
\text { по подготовке водителей }\end{array}$ & $\begin{array}{l}\text { Биржевые } \\
\text { облигации }\end{array}$ & + \\
\hline $\begin{array}{l}\mathrm{OOO} « \mathrm{C} Ф О \mathrm{MOC} \\
\mathrm{MC \Pi} 1 »\end{array}$ & $\begin{array}{l}\text { Поддержка малого и среднего } \\
\text { предпринимательства }\end{array}$ & Облигации & - \\
\hline $\begin{array}{l}\text { OОO «СФО МОC } \\
\text { МСП } 3 »\end{array}$ & $\begin{array}{l}\text { Поддержка малого и среднего } \\
\text { предпринимательства }\end{array}$ & Облигации & - \\
\hline АО «ММЦБ» & $\begin{array}{l}\text { Обработки и криохранение биома- } \\
\text { териалов }\end{array}$ & $\begin{array}{l}\text { Биржевые } \\
\text { облигации } \\
\end{array}$ & + \\
\hline АО «ЮАИЗ» & $\begin{array}{l}\text { Производство материалов для ли- } \\
\text { ний электропередач }\end{array}$ & $\begin{array}{l}\text { Биржевые } \\
\text { облигации }\end{array}$ & - \\
\hline ООО «НЗРМ» & Обработка рулонной стали & $\begin{array}{l}\text { Биржевые } \\
\text { облигации }\end{array}$ & + \\
\hline ООО «ФЭС-Агро» & Аграрный сектор & $\begin{array}{l}\text { Биржевые } \\
\text { облигации }\end{array}$ & \\
\hline $\begin{array}{l}\text { ООО «ТАЛАН- } \\
\text { ФИНАНС» }\end{array}$ & Девелопмент & $\begin{array}{l}\text { Биржевые } \\
\text { облигации }\end{array}$ & + \\
\hline $\begin{array}{l}\text { АО «Коммерческая } \\
\text { недвижимость ФПК } \\
\text { «Гарант-Инвест» }\end{array}$ & $\begin{array}{l}\text { Управление коммерческой недви- } \\
\text { жимостью }\end{array}$ & $\begin{array}{l}\text { Биржевые } \\
\text { облигации }\end{array}$ & + \\
\hline $\begin{array}{l}\text { ООО «Брайт } \\
\text { Финанс» }\end{array}$ & Фитнес-индустрия & $\begin{array}{l}\text { Биржевые } \\
\text { облигации }\end{array}$ & + \\
\hline
\end{tabular}


Окончание приложения В

\begin{tabular}{|c|c|c|c|}
\hline Эмитент/Фонд & Отрасль/сектор & $\begin{array}{c}\text { Тип } \\
\text { инстру- } \\
\text { мента }\end{array}$ & $\begin{array}{c}\text { Субъект } \\
\text { МСП }\end{array}$ \\
\hline АО «ГК «Пионер» & Девелопмент & $\begin{array}{l}\text { Биржевые } \\
\text { облигации }\end{array}$ & + \\
\hline ООО «Легенда» & Девелопмент & $\begin{array}{l}\text { Биржевые } \\
\text { облигации }\end{array}$ & + \\
\hline $\begin{array}{l}\text { ООО «Агрофирма } \\
\text { Рубеж» }\end{array}$ & Аграрный сектор & $\begin{array}{l}\text { Биржевые } \\
\text { облигации }\end{array}$ & - \\
\hline ЗАО «Ламбумиз» & Производство упаковки & $\begin{array}{l}\text { Биржевые } \\
\text { облигации }\end{array}$ & + \\
\hline ООО «Каскад» & Оптовая торговля автозапчастями & $\begin{array}{l}\text { Биржевые } \\
\text { облигации }\end{array}$ & + \\
\hline $\begin{array}{l}\text { ООО } \\
\text { «С-Инновации» }\end{array}$ & $\begin{array}{l}\text { Производство высокотемператур- } \\
\text { ных сверхпроводников (ВТСП) } \\
\text { на металлических лентах 2-го по- } \\
\text { коления }\end{array}$ & $\begin{array}{l}\text { Биржевые } \\
\text { облигации }\end{array}$ & + \\
\hline ООО «Кузина» & Производство пищевых продуктов & $\begin{array}{l}\text { Биржевые } \\
\text { облигации }\end{array}$ & + \\
\hline $\begin{array}{l}\text { ООО НПП «Мотор- } \\
\text { ные технологии» }\end{array}$ & Производитель оборудования & $\begin{array}{l}\text { Биржевые } \\
\text { облигации }\end{array}$ & + \\
\hline ООО «ЭБИС» & Переработка материалов & $\begin{array}{l}\text { Биржевые } \\
\text { облигации }\end{array}$ & + \\
\hline $\begin{array}{l}\text { ПАО «СЭЗ им. Серго } \\
\text { Орджоникидзе» }\end{array}$ & Инжиниринговая компания & $\begin{array}{l}\text { Биржевые } \\
\text { облигации }\end{array}$ & - \\
\hline $\begin{array}{l}\text { ООО «Трейд } \\
\text { Менеджмент» }\end{array}$ & Розничная торговля & $\begin{array}{l}\text { Биржевые } \\
\text { облигации }\end{array}$ & - \\
\hline АО «ТРУД» & Дорожное строительство & $\begin{array}{l}\text { Биржевые } \\
\text { облигации }\end{array}$ & - \\
\hline $\begin{array}{l}\text { ООО «ЭнергоТех- } \\
\text { Сервис» }\end{array}$ & Энергетика & $\begin{array}{l}\text { Биржевые } \\
\text { облигации }\end{array}$ & - \\
\hline ООО «Завод КЭС» & Энергетика & $\begin{array}{l}\text { Биржевые } \\
\text { облигации }\end{array}$ & + \\
\hline $\begin{array}{l}\text { ООО «Сибирский } \\
\text { КХП» }\end{array}$ & Агропромышленность & $\begin{array}{l}\text { Биржевые } \\
\text { облигации }\end{array}$ & + \\
\hline
\end{tabular}

Источник: Сектор Роста // Московская биржа: сайт. - URL: https://www.moex. com/s2151 (дата обращения: 01.01.2020). 
Приложение Г

\section{Метод углубленного декаплинг-анализа ${ }^{11}$}

Эффект «декаплинга» оценивается на основе индекса декаплинга (DI) за определенный период времени (как правило, год) по формуле П1):

$$
\mathrm{DI}=\mathrm{T}_{\mathrm{R}} / \mathrm{T}_{\mathrm{Y}},
$$

где $\mathrm{T}_{\mathrm{R}}$ - относительное изменение (коэффициент роста) потребляемого ресурса или выброса загрязнения за определенный период;

$\mathrm{T}_{\text {у }}$ - относительное изменение (коэффициент роста) результирующего показателя (как правило ВВП, ВРП, т.п.) за аналогичный период;

DI - индекс декаплинга, выраженный в относительных единицах;

при DI > 1,0 - эффект «декаплинга» отсутствует - потребление ресурсов или загрязнение окружающей среды происходит более быстрыми темпами, чем экономический рост, происходит интенсивное загрязнение окружающей среды;

при $\mathrm{DI}=1,0$ темпы экономического роста и загрязнения окружающей среды одинаковы;

при 1,0 < DI наблюдается эффект «декаплинга» - темпы экономического роста выше, чем темпы загрязнения окружающей среды.

Индекс декаплинга, рассчитанный по формуле (П1), дает возможность оценить наличие эффекта «декаплинга», но не показывает, является ли этот эффект абсолютным или относительным. Также отсутствует возможность более глубоких выводов об эколого-экономическом состоянии региона. Для преодоления этих недостатков автором предлагается модель анализа эффекта «декаплинга». Модель (рис. П1) основана на сопоставлении коэффициентов прироста потребляемых ресурсов и/или загрязнений и показателями экономического роста. Скорректированный индекс декаплинга в модели рассчитывается по следующей формуле (П2):

$$
\mathrm{DI}^{\prime}=\mathrm{T}_{\mathrm{R}}{ }^{\prime}-\mathrm{T}_{\mathrm{Y}}{ }^{\prime},
$$

где $\mathrm{DI}^{\prime}$ - скорректированный индекс декаплинга, выраженный в относительных единицах,

${ }^{11}$ Источник: авторская разработка, опубликовано: Аникин А.А. Экологоэкономическое развитие регионов: совершенствование методологии и методики оценки / И.Д. Аникина, А.А. Аникин. Волгоград: изд-во ВолГУ, 2019. 196 с. С. 81-85. 
$\mathrm{T}_{\mathrm{R}}{ }^{\prime}$ - коэффициент прироста потребляемого ресурса или выброса загрязнения за определенный период, отн. Ед.,

$\mathrm{T}_{\mathrm{Y}}{ }^{\prime}$ - коэффициент прироста результирующего показателя за аналогичный период, отн. Ед.

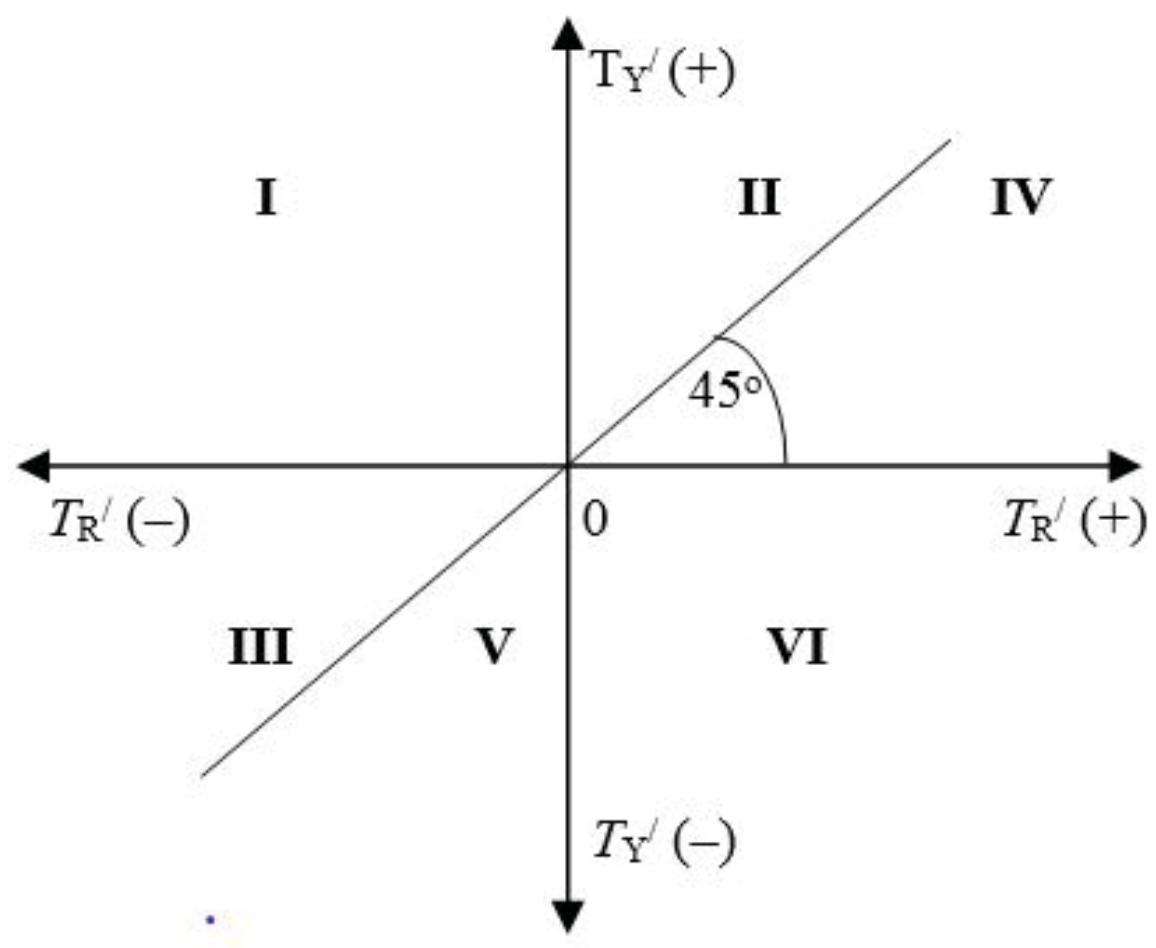

Рис. П1. Модель оценки эффекта декаплинга Источник: авторская модель.

Модель позволяет выделить шесть секторов, характеризующих различную степень эффективности эколого-экономического состояния региона. На рисунке П1 секторы пронумерованы от наилучшего к наихудшему.

Сектор I: $\mathrm{T}_{\mathrm{R}}^{\prime}(-)<\mathrm{T}_{\mathrm{Y}}^{\prime}(+), \mathrm{DI}^{\prime}<0$. Наличие эффекта «абсолютного декаплинга». Наиболее благоприятная ситуация для экономики региона, характеризующаяся снижением экологической нагрузки в регионе при одновременном экономическом росте, устойчивое развитие региона.

Сектор II: $\mathrm{T}_{\mathrm{R}}^{\prime}(+; 0,0)<\mathrm{T}_{\mathrm{Y}}^{\prime}(+), \mathrm{DI}^{\prime}<0,0$ либо $=0,0$. Наличие эффекта «относительного декаплинга». «Нормальный экономический рост». Нормальная ситуация, рост эффективности экономики региона сопровождается ростом экологических издержек, растет негативное воздей- 
ствие на окружающую среду, но индекс декаплинга остается отрицательной величиной, что говорит об устойчивом развитии региона.

Сектор III: $\mathrm{T}_{\mathrm{R}}^{\prime}(-; 0,0)>\mathrm{T}_{\mathrm{Y}}^{\prime}(-; 0,0), \mathrm{DI}^{\prime}<0,0$ либо $=0,0$. Наличие эффекта «относительного декаплинга». Ситуация характеризуется снижением экологической нагрузки на регион при одновременном снижении ВРП, но экологическая нагрузка снижается быстрее экономических результатов. Такая ситуация возможна в условиях реструктуризации производств, перехода на новые инновационные технологии.

Сектор IV: $\mathrm{T}_{\mathrm{R}}^{\prime}(+)>\mathrm{T}_{\mathrm{Y}}^{\prime}(+), \mathrm{DI}^{\prime}>0$. Эффект «декаплинга» отсутствует. Замедление эффективности эколого-экономического развития региона. «Бурый» экономический рост. Происходит ускоренная нагрузка на экологическое состояние региона, но наблюдается и экономический рост. Необходимо уделять внимание поддержке «зеленых» технологий и проектов.

Сектор V: $\mathrm{T}_{\mathrm{R}}^{\prime}(-)<\mathrm{T}_{\mathrm{Y}}^{\prime}(-), \mathrm{DI}^{\prime}>0$. Эффект «декаплинга» отсутствует. Для данной ситуации характерно снижение экологической нагрузки при одновременно большем ухудшении показателей эффективности региональной экономики.

Сектор VI: $\mathrm{T}_{\mathrm{R}}^{\prime}(+)>\mathrm{T}_{\mathrm{Y}}^{\prime}(-), \mathrm{DI}^{\prime}>0$. Эффект «декаплинга» отсутствует. Наихудшая, кризисная ситуация, при которой рост нагрузки на экологию региона сопровождается ухудшением экономической ситуации.

Предложенная модель позволяет выявить секторы, характеризующие качественно различную степень эффективности реализации эколого-экономической политики региона, что поможет своевременно диагностировать экологические и экономические проблемы региона и принять соответствующие решения о мерах поддержки экологических проектов и программ, целесообразности их продолжения, корректировки, реструктуризации.

На основе скорректированного индекса декаплинга предлагается рассчитывать рейтинг «эколого-экономической привлекательности» региона (формула П3):

$$
\text { Reea }=\sum \mathrm{r}_{\mathrm{i}} \times \mathrm{f}_{\mathrm{i}} / \sum \mathrm{f}_{\mathrm{i}}
$$

где Reea - рейтинг эколого-экономической привлекательности региона; Reea $=[1 \div 6]$;

$\mathrm{r}_{\mathrm{i}}$ - номер сектора декаплинг-анализа, $\mathrm{ri}=[1,2, \ldots 6]$;

$\mathrm{f}_{\mathrm{i}}$ - номер анализируемого периода, $\mathrm{fi}=[1,2, \ldots \mathrm{n}]$;

$\mathrm{n}$ - количество анализируемых периодов. 
Рейтинг может быть использован инвесторами для оценки региональных рисков при инвестировании в региональные экологические проекты.

Предложенные модели и могут быть использованы для мониторинга эколого-экономического состояния региона, а также при разработке и корректировке эколого-экономических программ развития регионов.

Представленную модель анализа эффекта «декаплинга» считаем возможным применить для оценки эколого-экономического состояния регионов и механизмов поддержки «зеленых» проектов, для мониторинга внедрения инновационных эколого-сберегающих технологий. Оценка не только наличия или отсутствия эффекта «декаплинга», но и его более глубокий анализ, позволит делать выводы об инвестиционной привлекательности региона для внедрения инновационных проектов в области «зеленых» технологий, выбору оптимальных источников финансирования и их параметров. 
Приложение Д

Рейтинг «эколого-экономического риска» российских регионов

\begin{tabular}{|c|c|c|c|c|}
\hline $\begin{array}{c}\text { № } \\
\text { ПI/I }\end{array}$ & \begin{tabular}{|c|} 
Рейтинг \\
«эколого- \\
экономиче- \\
ского риска» \\
регионов \\
\end{tabular} & Регионы & $\begin{array}{c}\text { Рейтинговая } \\
\text { шкала } \\
\text { «зеленых» } \\
\text { ценных } \\
\text { бумаг } \\
\end{array}$ & $\begin{array}{c}\text { Характеристика } \\
\text { рейтинговой } \\
\text { шкалы }\end{array}$ \\
\hline 1 & 1,14 & Липецкая область & $\mathrm{A}+$ & $\begin{array}{l}\text { Низкий уровень } \\
\text { риска }\end{array}$ \\
\hline 2 & 1,43 & Тульская область & $\mathrm{A}+$ & $\begin{array}{l}\text { Низкий уровень } \\
\text { риска }\end{array}$ \\
\hline 3 & 1,57 & Архангельская область & $\mathrm{A}+$ & $\begin{array}{l}\text { Низкий уровень } \\
\text { риска }\end{array}$ \\
\hline 4 & 1,62 & Белгородская область & $\mathrm{A}+$ & $\begin{array}{l}\text { Низкий уровень } \\
\text { риска }\end{array}$ \\
\hline 5 & 1,81 & Вологодская область & $\mathrm{A}+$ & $\begin{array}{l}\text { Низкий уровень } \\
\text { риска }\end{array}$ \\
\hline 6 & 1,86 & Иркутская область & $\mathrm{A}+$ & $\begin{array}{l}\text { Низкий уровень } \\
\text { риска }\end{array}$ \\
\hline 7 & 1,91 & Курская область & $\mathrm{A}+$ & $\begin{array}{l}\text { Низкий уровень } \\
\text { риска }\end{array}$ \\
\hline 8 & 1,95 & Новгородская область & $\mathrm{A}+$ & $\begin{array}{l}\text { Низкий уровень } \\
\text { риска }\end{array}$ \\
\hline 9 & 1,95 & Свердловская область & $\mathrm{A}+$ & $\begin{array}{l}\text { Низкий уровень } \\
\text { риска }\end{array}$ \\
\hline 10 & 2,05 & Ульяновская область & A & $\begin{array}{l}\text { Удовлетворительный } \\
\text { уровень риска }\end{array}$ \\
\hline 11 & 2,05 & Челябинская область & A & $\begin{array}{l}\text { Удовлетворительный } \\
\text { уровень риска }\end{array}$ \\
\hline 12 & 2,10 & $\begin{array}{l}\text { Республика Саха } \\
\text { (Якутия) }\end{array}$ & A & $\begin{array}{l}\text { Удовлетворительный } \\
\text { уровень риска }\end{array}$ \\
\hline 13 & 2,19 & Республика Мордовия & A & $\begin{array}{l}\text { Удовлетворительный } \\
\text { уровень риска }\end{array}$ \\
\hline 14 & 2,23 & Мурманская область & A & $\begin{array}{l}\text { Удовлетворительный } \\
\text { уровень риска }\end{array}$ \\
\hline 15 & 2,33 & Красноярский край & A & $\begin{array}{l}\text { Удовлетворительный } \\
\text { уровень риска }\end{array}$ \\
\hline
\end{tabular}


Продолжение приложения Д

\begin{tabular}{|c|c|c|c|c|}
\hline $\begin{array}{l}\text { № } \\
\Pi / \Pi\end{array}$ & $\begin{array}{c}\text { Рейтинг } \\
\text { «эколого- } \\
\text { экономиче- } \\
\text { ского риска» } \\
\text { регионов }\end{array}$ & Регионы & $\begin{array}{c}\text { Рейтинговая } \\
\text { шкала } \\
\text { «зеленых» } \\
\text { ценных } \\
\text { бумаг }\end{array}$ & $\begin{array}{c}\text { Характеристика } \\
\text { рейтинговой } \\
\text { шкалы }\end{array}$ \\
\hline 16 & 2,38 & Удмуртская Республика & A & $\begin{array}{l}\text { Удовлетворительный } \\
\text { уровень риска }\end{array}$ \\
\hline 17 & 2,48 & Саратовская область & A & $\begin{array}{l}\text { Удовлетворительный } \\
\text { уровень риска }\end{array}$ \\
\hline 18 & 2,48 & Республика Тыва & A & $\begin{array}{l}\text { Удовлетворительный } \\
\text { уровень риска }\end{array}$ \\
\hline 19 & 2,48 & Хабаровский край & A & $\begin{array}{l}\text { Удовлетворительный } \\
\text { уровень риска }\end{array}$ \\
\hline 20 & 2,52 & Владимирская область & A & $\begin{array}{l}\text { Удовлетворительный } \\
\text { уровень риска }\end{array}$ \\
\hline 21 & 2,57 & Чеченская Республика* & A & $\begin{array}{l}\text { Удовлетворительный } \\
\text { уровень риска }\end{array}$ \\
\hline 22 & 2,62 & Ростовская область & A & $\begin{array}{l}\text { Удовлетворительный } \\
\text { уровень риска }\end{array}$ \\
\hline 23 & 2,62 & $\begin{array}{l}\text { Чувашская Республи- } \\
\text { ка - Чувашия }\end{array}$ & A & $\begin{array}{l}\text { Удовлетворительный } \\
\text { уровень риска }\end{array}$ \\
\hline 24 & 2,67 & Воронежская область & A & $\begin{array}{l}\text { Удовлетворительный } \\
\text { уровень риска }\end{array}$ \\
\hline 25 & 2,67 & Московская область & A & $\begin{array}{l}\text { Удовлетворительный } \\
\text { уровень риска }\end{array}$ \\
\hline 26 & 2,71 & Брянская область & A & $\begin{array}{l}\text { Удовлетворительный } \\
\text { уровень риска }\end{array}$ \\
\hline 27 & 2,71 & Ярославская область & A & $\begin{array}{l}\text { Удовлетворительный } \\
\text { уровень риска }\end{array}$ \\
\hline 28 & 2,71 & Республика Марий Эл & A & $\begin{array}{l}\text { Удовлетворительный } \\
\text { уровень риска }\end{array}$ \\
\hline 29 & 2,76 & Ленинградская область & A & $\begin{array}{l}\text { Удовлетворительный } \\
\text { уровень риска }\end{array}$ \\
\hline 30 & 2,76 & Сахалинская область & A & $\begin{array}{l}\text { Приемлемый } \\
\text { уровень риска }\end{array}$ \\
\hline 31 & 2,81 & Республика Калмыкия & A & $\begin{array}{l}\text { Удовлетворительный } \\
\text { уровень риска }\end{array}$ \\
\hline 32 & 2,91 & Орловская область & A & $\begin{array}{l}\text { Удовлетворительный } \\
\text { уровень риска }\end{array}$ \\
\hline
\end{tabular}


Продолжение приложения Д

\begin{tabular}{|c|c|c|c|c|}
\hline $\begin{array}{c}\text { № } \\
\text { ПI/П }\end{array}$ & $\begin{array}{c}\text { Рейтинг } \\
\text { «эколого- } \\
\text { экономиче- } \\
\text { ского риска» } \\
\text { регионов }\end{array}$ & Регионы & $\begin{array}{c}\text { Рейтинговая } \\
\text { шкала } \\
\text { «зеленых» } \\
\text { ценных } \\
\text { бумаг }\end{array}$ & $\begin{array}{c}\text { Характеристика } \\
\text { рейтинговой } \\
\text { шкалы }\end{array}$ \\
\hline 33 & 2,95 & Тверская область & A & $\begin{array}{l}\text { Удовлетворительный } \\
\text { уровень риска }\end{array}$ \\
\hline 34 & 2,95 & $\begin{array}{l}\text { Новосибирская } \\
\text { область }\end{array}$ & A & $\begin{array}{l}\text { Удовлетворительный } \\
\text { уровень риска }\end{array}$ \\
\hline 35 & 3,00 & Костромская область & $\mathrm{B}+$ & $\begin{array}{l}\text { Приемлемый } \\
\text { уровень риска }\end{array}$ \\
\hline 36 & 3,00 & $\begin{array}{l}\text { Город Москва столица } \\
\text { Российской Федерации } \\
\text { город федерального } \\
\text { значения }\end{array}$ & $\mathrm{B}+$ & $\begin{array}{l}\text { Приемлемый } \\
\text { уровень риска }\end{array}$ \\
\hline 37 & 3,00 & $\begin{array}{l}\text { Республика Татарстан } \\
\text { (Татарстан) }\end{array}$ & $\mathrm{B}+$ & $\begin{array}{l}\text { Приемлемый } \\
\text { уровень риска }\end{array}$ \\
\hline 38 & 3,05 & Псковская область & $\mathrm{B}+$ & $\begin{array}{l}\text { Приемлемый } \\
\text { уровень риска }\end{array}$ \\
\hline 39 & 3,10 & Самарская область & $\mathrm{B}+$ & $\begin{array}{l}\text { Приемлемый } \\
\text { уровень риска }\end{array}$ \\
\hline 40 & 3,10 & Томская область & $\mathrm{B}+$ & $\begin{array}{l}\text { Приемлемый } \\
\text { уровень риска }\end{array}$ \\
\hline 41 & 3,10 & Магаданская область & $\mathrm{B}+$ & $\begin{array}{l}\text { Приемлемый } \\
\text { уровень риска }\end{array}$ \\
\hline 42 & 3,14 & Ивановская область & $\mathrm{B}+$ & $\begin{array}{l}\text { Приемлемый } \\
\text { уровень риска }\end{array}$ \\
\hline 43 & 3,14 & $\begin{array}{l}\text { Калининградская } \\
\text { область }\end{array}$ & $\mathrm{B}+$ & $\begin{array}{l}\text { Приемлемый } \\
\text { уровень риска }\end{array}$ \\
\hline 44 & 3,14 & Республика Хакасия & $\mathrm{B}+$ & $\begin{array}{l}\text { Приемлемый } \\
\text { уровень риска }\end{array}$ \\
\hline 45 & 3,14 & $\begin{array}{l}\text { Карачаево-Черкесская } \\
\text { Республика }\end{array}$ & $\mathrm{B}+$ & $\begin{array}{l}\text { Приемлемый } \\
\text { уровень риска }\end{array}$ \\
\hline 46 & 3,14 & Камчатский край & $\mathrm{B}+$ & $\begin{array}{l}\text { Приемлемый } \\
\text { уровень риска }\end{array}$ \\
\hline 47 & 3,19 & Астраханская область & $\mathrm{B}+$ & $\begin{array}{l}\text { Приемлемый } \\
\text { уровень риска }\end{array}$ \\
\hline 48 & 3,19 & Курганская область & $\mathrm{B}+$ & $\begin{array}{l}\text { Приемлемый } \\
\text { уровень риска }\end{array}$ \\
\hline
\end{tabular}


Продолжение приложения Д

\begin{tabular}{|c|c|c|c|c|}
\hline $\begin{array}{l}\text { № } \\
\text { ПI/ா }\end{array}$ & \begin{tabular}{|c|} 
Рейтинг \\
«эколого- \\
экономиче- \\
ского риска» \\
регионов \\
\end{tabular} & Регионы & \begin{tabular}{|c} 
Рейтинговая \\
шкала \\
«зеленых» \\
ценных \\
бумаг \\
\end{tabular} & $\begin{array}{c}\text { Характеристика } \\
\text { рейтинговой } \\
\text { шкалы }\end{array}$ \\
\hline 49 & 3,29 & Республика Карелия & $\mathrm{B}^{+}$ & $\begin{array}{l}\text { Приемлемый } \\
\text { уровень риска }\end{array}$ \\
\hline 50 & 3,29 & Республика Коми & $\mathrm{B}^{+}$ & $\begin{array}{l}\text { Приемлемый } \\
\text { уровень риска }\end{array}$ \\
\hline 51 & 3,33 & $\begin{array}{l}\text { Нижегородская } \\
\text { область }\end{array}$ & $\mathrm{B}^{+}$ & $\begin{array}{l}\text { Приемлемый } \\
\text { уровень риска }\end{array}$ \\
\hline 52 & 3,38 & $\begin{array}{l}\text { Республика Башкорто- } \\
\text { стан }\end{array}$ & $\mathrm{B}^{+}$ & \begin{tabular}{|l} 
Приемлемый \\
уровень риска
\end{tabular} \\
\hline 53 & 3,43 & Тамбовская область & $\mathrm{B}^{+}$ & $\begin{array}{l}\text { Приемлемый } \\
\text { уровень риска }\end{array}$ \\
\hline 54 & 3,43 & Омская область & $\mathrm{B}^{+}$ & $\begin{array}{l}\text { Приемлемый } \\
\text { уровень риска }\end{array}$ \\
\hline 55 & 3,48 & Пермский край & $\mathrm{B}^{+}$ & $\begin{array}{l}\text { Приемлемый } \\
\text { уровень риска }\end{array}$ \\
\hline 56 & 3,48 & $\begin{array}{l}\text { Республика Северная } \\
\text { Осетия-Алания }\end{array}$ & $\mathrm{B}^{+}$ & \begin{tabular}{|l} 
Приемлемый \\
уровень риска
\end{tabular} \\
\hline 57 & 3,52 & Республика Алтай & $\mathrm{B}^{+}$ & $\begin{array}{l}\text { Приемлемый } \\
\text { уровень риска }\end{array}$ \\
\hline 58 & 3,57 & $\begin{array}{l}\text { Чукотский автономный } \\
\text { округ }\end{array}$ & $\mathrm{B}^{+}$ & \begin{tabular}{|l} 
Приемлемый \\
уровень риска
\end{tabular} \\
\hline 59 & 3,62 & Калужская область & $\mathrm{B}^{+}$ & $\begin{array}{l}\text { Приемлемый } \\
\text { уровень риска }\end{array}$ \\
\hline 60 & 3,62 & Кировская область & $\mathrm{B}^{+}$ & \begin{tabular}{|l} 
Приемлемый \\
уровень риска
\end{tabular} \\
\hline 61 & 3,71 & $\begin{array}{l}\text { Кабардино-Балкарская } \\
\text { Республика }\end{array}$ & $\mathrm{B}^{+}$ & $\begin{array}{l}\text { Приемлемый } \\
\text { уровень риска }\end{array}$ \\
\hline 62 & 3,76 & Волгоградская область & $\mathrm{B}^{+}$ & \begin{tabular}{|l} 
Приемлемый \\
уровень риска
\end{tabular} \\
\hline 63 & 3,81 & Смоленская область & $\mathrm{B}^{+}$ & $\begin{array}{l}\text { Приемлемый } \\
\text { уровень риска }\end{array}$ \\
\hline 64 & 3,81 & \begin{tabular}{|l} 
Город Санкт-Петербург \\
город федерального \\
значения
\end{tabular} & $\mathrm{B}^{+}$ & $\begin{array}{l}\text { Приемлемый } \\
\text { уровень риска }\end{array}$ \\
\hline
\end{tabular}


Окончание приложения Д

\begin{tabular}{|c|c|c|c|c|}
\hline $\begin{array}{c}\text { № } \\
\Pi / \mathbf{\Pi}\end{array}$ & $\begin{array}{c}\text { Рейтинг } \\
\text { «эколого- } \\
\text { экономиче- } \\
\text { ского риска» } \\
\text { регионов }\end{array}$ & Регионы & \begin{tabular}{|} 
Рейтинговая \\
шкала \\
«зеленых» \\
ценных \\
бумаг
\end{tabular} & $\begin{array}{c}\text { Характеристика } \\
\text { рейтинговой } \\
\text { шкалы }\end{array}$ \\
\hline 65 & 3,81 & Забайкальский край & $\mathrm{B}+$ & $\begin{array}{l}\text { Приемлемый } \\
\text { уровень риска }\end{array}$ \\
\hline 66 & 3,86 & Республика Бурятия & $\mathrm{B}+$ & $\begin{array}{l}\text { Приемлемый } \\
\text { уровень риска }\end{array}$ \\
\hline 67 & 3,91 & Республика Дагестан & $\mathrm{B}+$ & $\begin{array}{l}\text { Приемлемый } \\
\text { уровень риска }\end{array}$ \\
\hline 68 & 3,91 & Ставропольский край & $\mathrm{B}+$ & $\begin{array}{l}\text { Приемлемый } \\
\text { уровень риска }\end{array}$ \\
\hline 69 & 3,91 & Тюменская область & $\mathrm{B}+$ & $\begin{array}{l}\text { Приемлемый } \\
\text { уровень риска }\end{array}$ \\
\hline 70 & 3,91 & Амурская область & $\mathrm{B}+$ & $\begin{array}{l}\text { Приемлемый } \\
\text { уровень риска }\end{array}$ \\
\hline 71 & 3,95 & Рязанская область & $\mathrm{B}+$ & $\begin{array}{l}\text { Приемлемый } \\
\text { уровень риска }\end{array}$ \\
\hline 72 & 4,00 & Республика Адыгея & B & $\begin{array}{l}\text { Высокий уровень } \\
\text { риска }\end{array}$ \\
\hline 73 & 4,00 & Алтайский край & B & $\begin{array}{l}\text { Высокий уровень } \\
\text { риска }\end{array}$ \\
\hline 74 & 4,05 & Приморский Край & B & $\begin{array}{l}\text { Высокий уровень } \\
\text { риска }\end{array}$ \\
\hline 75 & 4,10 & Республика Ингушетия & $\mathrm{B}$ & $\begin{array}{l}\text { Высокий уровень } \\
\text { риска }\end{array}$ \\
\hline 76 & 4,23 & Краснодарский край & B & $\begin{array}{l}\text { Высокий уровень } \\
\text { риска }\end{array}$ \\
\hline 77 & 4,29 & Пензенская область & B & $\begin{array}{l}\text { Высокий уровень } \\
\text { риска }\end{array}$ \\
\hline 78 & 4,43 & Оренбургская область & $\mathrm{B}$ & $\begin{array}{l}\text { Высокий уровень } \\
\text { риска }\end{array}$ \\
\hline 79 & 4,43 & $\begin{array}{l}\text { Еврейская автономная } \\
\text { область }\end{array}$ & B & $\begin{array}{l}\text { Высокий уровень } \\
\text { риска }\end{array}$ \\
\hline 80 & 4,71 & Кемеровская область & $\mathrm{B}$ & $\begin{array}{l}\text { Высокий уровень } \\
\text { риска }\end{array}$ \\
\hline
\end{tabular}

Источник: расчеты автора. 
Научное издание

Аникин Андрей Андреевич

\section{ФИНАНСОВЫЙ ИНСТРУМЕНТАРИЙ \\ СТИМУЛИРОВАНИЯ «ЗЕЛЕНЫХ» ПРОЕКТОВ \\ В РОССИЙСКОЙ ЭКОНОМИКЕ: \\ ПРОБЛЕМЫ И НАПРАВЛЕНИЯ РАЗВИТИЯ}

Сетевое научное издание

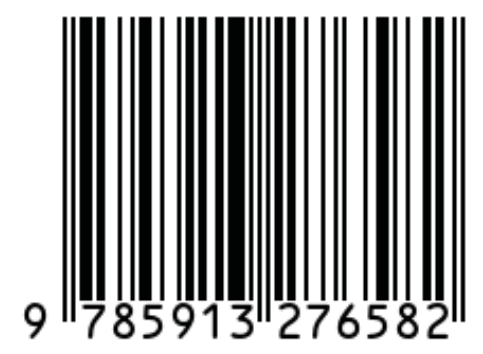

(C) А.А. Аникин, 2020

(C) ИД «Академия Естествознания»

(C) $\mathrm{AHO} \mathrm{«Академия} \mathrm{Естествознания»}$ 